\title{
Un conjunto constructivo altomedieval. Quintanilla de Las Viñas y las iglesias con cúpulas sobre pechinas de piedra toba de las provincias de Álava, La Rioja y Burgos
}

\author{
A High Middle Age complex. Quintanilla de las Viñas and tufa-stones \\ pendentive domed churches from Álava, La Rioja and Burgos provinces
}

\author{
Luis Caballero Zoreda
}

Instituto de Historia. Consejo Superior de Investigaciones Científicas. Madrid e-mail: luis.caballero@cchs.csic.es

\section{RESUMEN}

Se estudian las formas arquitectónicas y estructurales, conservadas o arruinadas, los usos constructivos y las soluciones decorativas empleados en el conjunto formado por las iglesias con cúpulas sobre pechinas de piedra toba de las provincias de Álava, La Rioja y Burgos. Primero se analizan los edificios; en segundo lugar, la producción constructiva y decorativa; y finalmente, con los datos obtenidos, se argumenta la datación del conjunto en época altomedieval, entre la segunda mitad del s. IX e inicios del s. X. Estos sistemas arquitectónicos, constructivos y decorativos suponen la existencia de varios grupos productivos que conformaron un conjunto unitario durante el tiempo y en el territorio en que estuvo activo.

Palabras clave: Arqueología de la arquitectura; Escultura decorativa; Estuco; Condado de Lara; Flámola; Siglos IX y X; San Martín de Elines; San Román de Tobillas; San Miguel de Montoria; Santa María de Los Arcos de Tricio; Santa Coloma; Las Tapias de Albelda de Iregua; Santa María de Ventas Blancas; San Esteban de La Canejada; Santas Céntola y Elena de Siero; San Felices de Oca; San Vicente del Valle; San Pedro el Viejo de Arlanza; Santa Cecilia de Tabladillo; Nuestra Señora de Las Heras de Hérmedes de Cerrato; Provincias de Santander y Palencia.

\begin{abstract}
Architectonic and structural forms, both preserved and ruined, are studied in this paper, as well as constructive customs and decorative solutions, in a group of tufa-stone pendentive domed churches from Álava, La Rioja and Burgos provinces. In a first step buildings are analyzed; secondly, decorative and constructive production is studied; and finally, datation of High Middle Age complex -between second half of the Ninth Century and the beginning of Tenth Century- is discussed since obtained data. These architectonic, constructive and decorative systems imply the existence of various productive groups which define a singular ensemble during the period of time and for the place in which this ensemble was active.
\end{abstract}

Keywords: Archaeology of Architecture; Decorative sculpture; Plaster; County of Lara; Flámola; Ninth and Tenth Centuries; San Martin de Elines; San Roman de Tobillas; San Miguel de Montoria; Santa María de los Arcos de Tricio; Santa Coloma; Las Tapias de Albelda; Santa María de Ventas Blancas; San Esteban de La Canejada; Santas Céntola y Elena de Siero; San Felices de Oca; San Vicente del Valle; San Pedro el Viejo de Arlanza; Santa Cecilia de Tabladillo; Nuestra Señora de Las Heras de Hérmedes de Cerrato; Santander Province; Palencia Province.

Recibido: 10-02-2015. Aceptado: 06-05-2015.

Cómo citar este artículo / Citation

Caballero Zoreda, L. 2015: "Un conjunto constructivo altomedieval. Quintanilla de Las Viñas y las iglesias con cúpulas sobre pechinas de piedra toba de las provincias de Álava, La Rioja y Burgos", Arqueología de la Arquitectura, 12: e028. doi: http://dx.doi.org/10.3989/arq.arqt.2015.011

Copyright

(c) 2015 CSIC. Este es un artículo de acceso abierto distribuido bajo los términos de la licencia Creative Commons Attribution-Non Commercial (by-nc) Spain 3.0. 


\section{QUINTANILLA DE LAS VIÑAS (BURGOS)}

Iniciamos el análisis por el edificio de Quintanilla de las Viñas, el más complejo y protagonista del conjunto. Del edificio originario solo queda en pie parte de los muros del ábside y el transepto. Los giros en la cabeza de estos muros son indicio de que, al margen de la decoración, se terminó por completo, sufriendo a continuación una ruina catastrófica. (Figs. 1 a 3. 22,7 x 21 m. Arbeiter 1990 y 2001; Utrero 2006: 151, 164-169, 235-236, $263,511-512$ y las fichas de cada edificio. A favor de la finalización del edificio: Íñiguez 1955; Kingsley 1980; Arbeiter 2001; Utrero 2006; en contra: Conant 1955; Lambert 1955; Palol 1956; Yarza 1979).

La construcción reutiliza sillares de origen romano. La piedra empleada es de tres tipos, arenisca marrón y calizas amarilla y blanca, lo que indica procedencias distintas y uso especializado. También se reutilizan fustes de mármol en las columnas de la embocadura del ábside. Para el abovedamiento se emplea toba calcárea extraída de cantera superficial. Los muros de carga son de dos hojas $(0,9 \mathrm{~m})$, sin núcleo, de sillares sin atizonar, trazados para su recorte con regla y ajustados a pie de

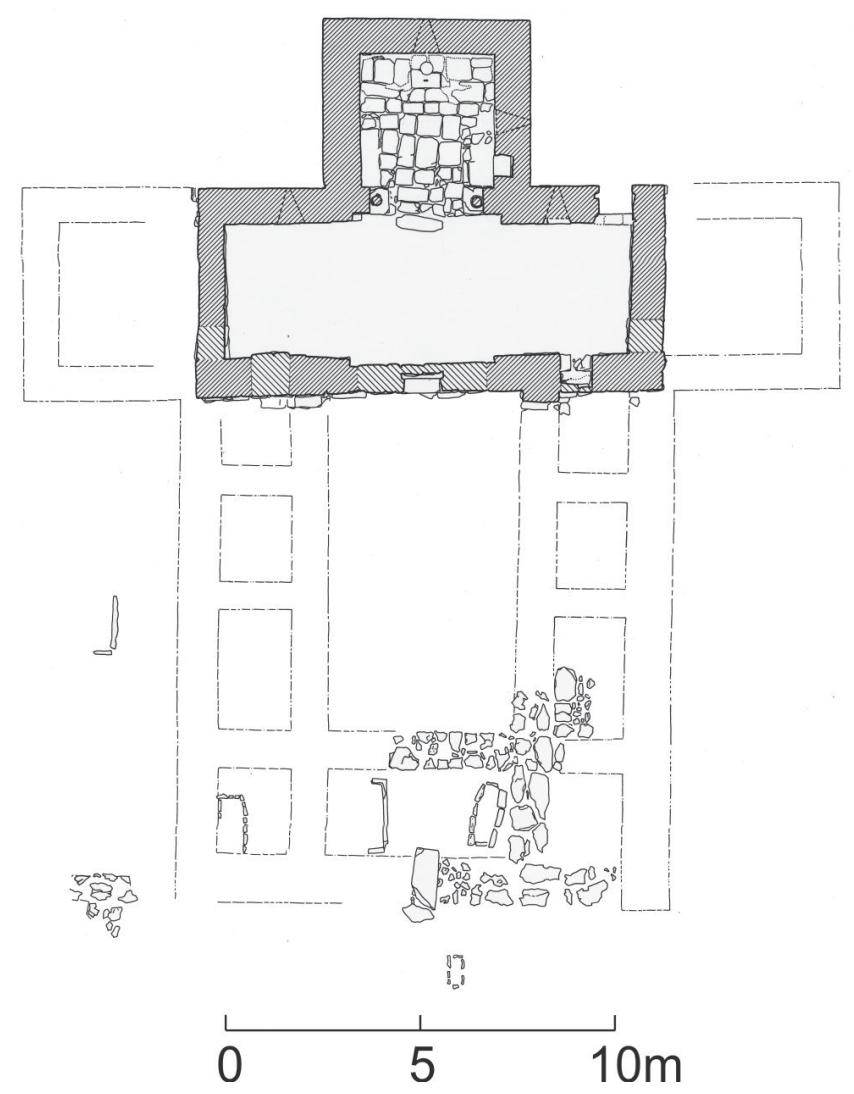

Figura 1.- Planta de la iglesia de Quintanilla de las Viñas (prov. Burgos). Escala 1/200 (según Arbeiter 1990). obra, que conservan las huellas de careado de sus aristas y las de desbaste de sus caras. Debido al corte a regla, el aparejo presenta sillares en forma de cuña, juntas oblicuas y escalonadas, coincidencia de juntas verticales y desdoble de hiladas. Las hiladas tienden a ser regulares, pero con ligeras ondulaciones. Los sillares se agrupan por zonas e hiladas según sus tamaños y formas: en ocasiones, rectangulares alargados, que llegan a los tres metros de longitud, y en otras, "semicuadrados", que asemejan tizones, aunque todos ocupan una hoja. El ajuste y enjarje de las dos hojas de sillares se utilizó para reforzar la estabilidad del muro.

La parte delantera de la iglesia conserva los muros del ábside, de planta cuadrada exenta, y un transepto tripartito, con un crucero, y los cimientos de dos habitaciones laterales exentas. Del aula sólo se conoce la planta de los cimientos por las excavaciones que, tras levantar una necrópolis medieval superpuesta a la ruina, descubrió "abundantes restos de cimentación" y "zanjas" expoliadas, las cuales fueron posteriormente rellenadas. De acuerdo con la documentación de estos trabajos, el cruce de sendos cimientos paralelos a los tres perimetrales individualiza una sala o nave central $\mathrm{y}$ tres habitaciones en el frente occidental (porche y habitaciones de esquina). Otros cimientos transversales separan tres habitaciones o naves a cada lado de la sala (obras dirigidas por Monteverde, Martínez Burgos e Íñiguez en 1935 y 1952. Camps 1940: 640, n. 4; Osaba 1952: 34-35; Íñiguez 1955: 80-81, 89 y figs. 103-107; Arbeiter 1990: fig. 5).

El acceso principal a la iglesia se hacía por su fachada occidental, a través del porche de cuyas puertas se conservan indicios. Las habitaciones que tenía a sus lados y los muros de carga que los separan pudieron sostener una tribuna alta. De ser así, las habitaciones contendrían sus escaleras (Schlunk y Hauschild 1978: 95, como Nazaré, y 232. Arbeiter 1990: 419, n. 67; Arbeiter 2001: 72. Caballero y Arce 2004: 185, fig. 59). Aula y transepto se separan por un muro transversal, en el cual se abren tres vanos de comunicación (Figs. 2c y e y 3). La sala central comunica con el crucero por un paso central, hoy tapiado. Las otras dos puertas comunican los espacios laterales del aula con las alas del transepto. La puerta sur, conservada, ofrece en el lado del aula un dintel y en el del transepto un arco de ligera herradura, con pequeñas nacelas y salmeres atizonados, que podía actuar de mocheta para el cierre de una puerta de madera que abriera hacia el aula, que no llegó a colocarse pues no existen quicios en su intradós (Íñiguez 1955). 


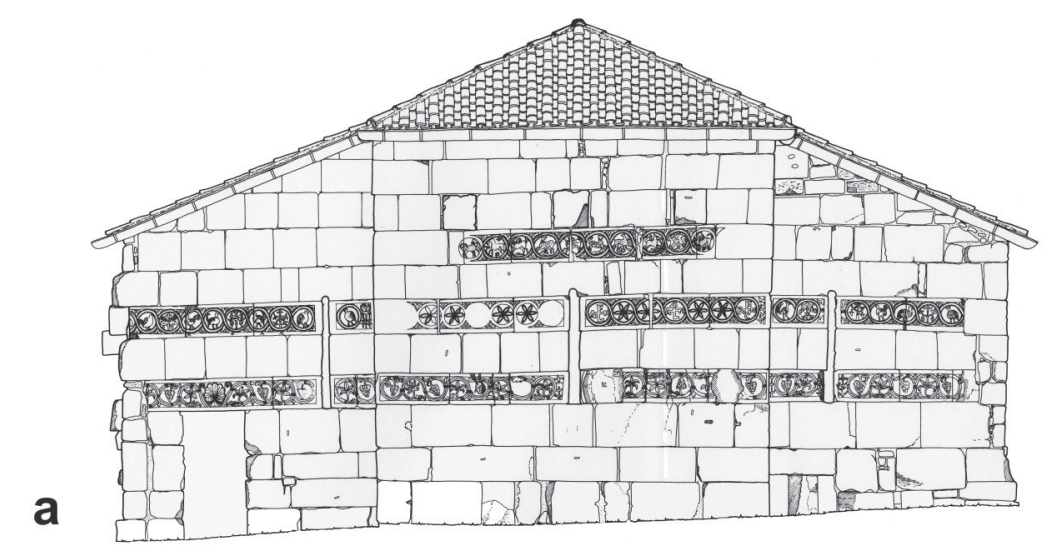

\section{b}
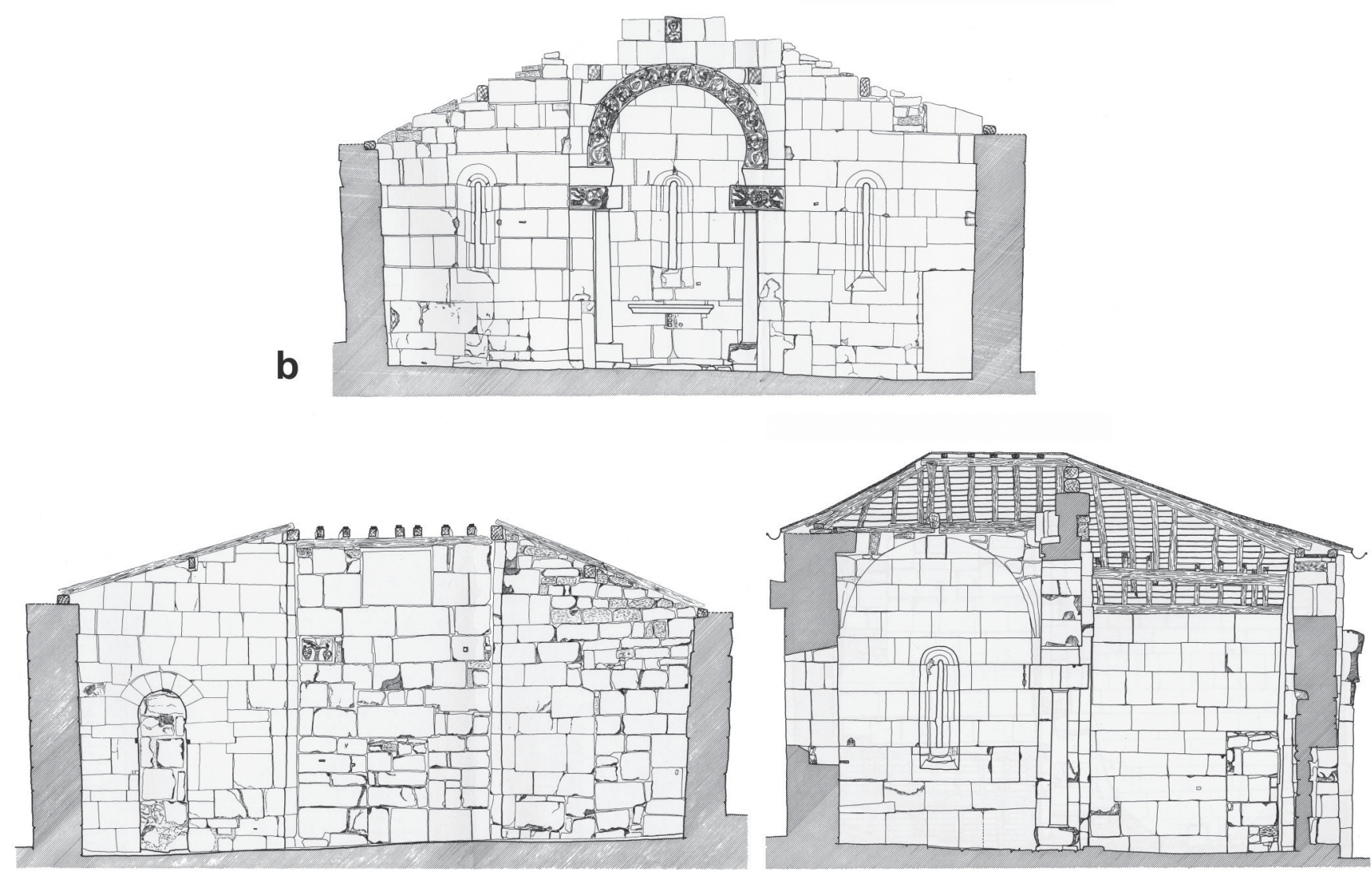

C

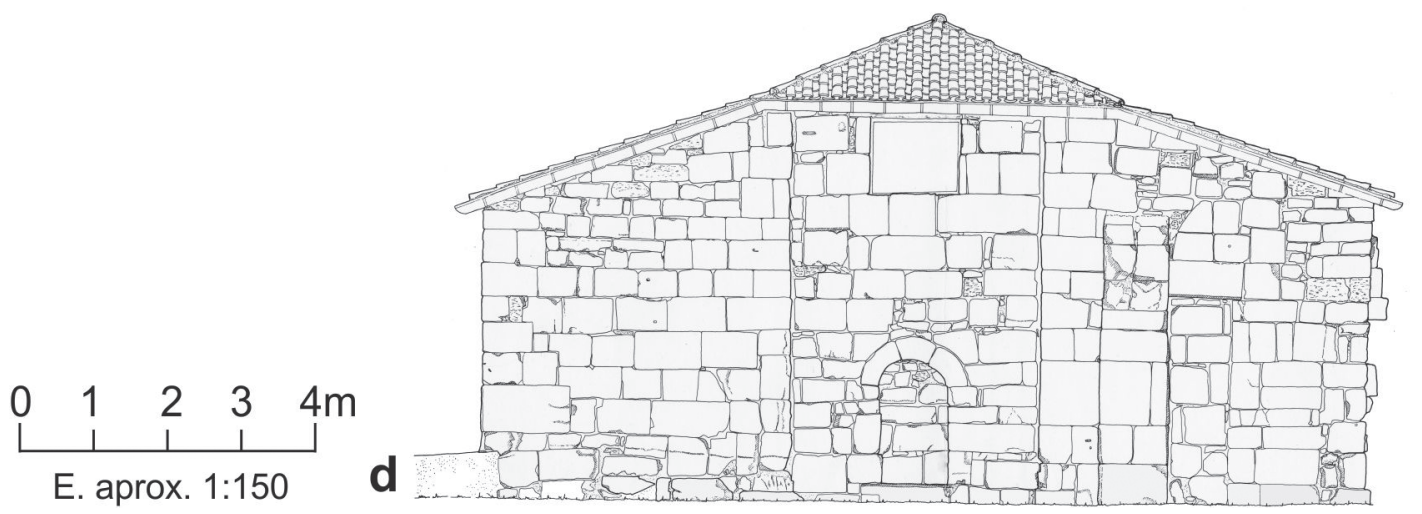

Figura 2.- Quintanilla. A, alzado este; B, sección a este; C, sección a oeste; D, sección a sur; E, alzado oeste. Escala 1/133 (según Arbeiter 1990). 


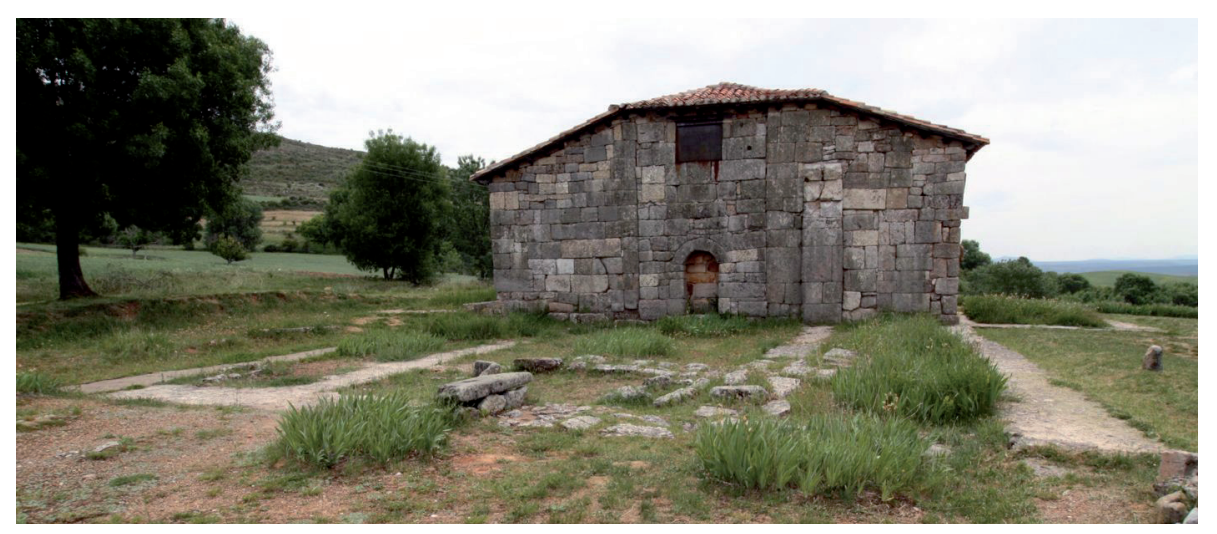

Figura 3.- Quintanilla. Vista general desde oeste.

El acceso al ábside se efectúa por un arco de herradura, trasdosado, con la arquivolta resaltada y decorada (Figs. 2 b y 4). Una pareja de columnas aparentan soportar el arco. Sus fustes asientan sobre sillares que actúan de basa y culminan con parejas de sillares que remedan la función de desproporcionados capiteles con sus frentes tallados con relieves. Sobre ellos otros sillares actúan de cimacio, con sus caras proximales oblicuas, lo que vuela el arranque del arco dándole un aspecto de nacela. En los extremos occidentales de los testeros norte y sur del transepto se abren otras puertas adinteladas para acceder a las habitaciones exentas que no tendrían puertas al exterior (sacristías). Una quinta puerta, también adintelada, por la que se accedía desde el exterior, se sitúa en el extremo sur del muro oriental del transepto. Estas puertas no poseen mochetas. El transepto posee dos ventanas en los muros orientales y el ábside, otras dos en el oriental y el meridional. Todas en forma de aspillera, cubiertas con dinteles recortados en forma de arco, que denominamos a partir de ahora "dinteles arcuados". Se conservan además, sueltos en el edificio, un dintel arcuado como el de las ventanas dichas y un salmer perteneciente a un arco geminado de herradura (ajimez), ambos de ventanas cuyo número y posición desconocemos (Fig. 5).

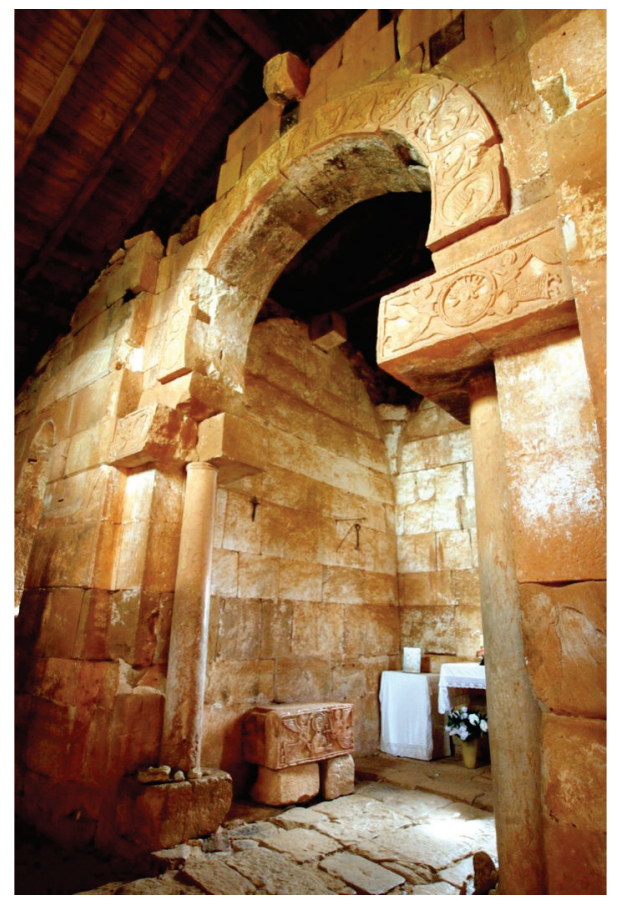

Figura 4.- Quintanilla. Arco de acceso al ábside.

La iglesia funciona con dos zonas diferenciadas, cada una con su acceso propio. La occidental formada por el porche, el aula, con su sala, sus habitaciones laterales y una posible tribuna; y la oriental, por el transepto, las
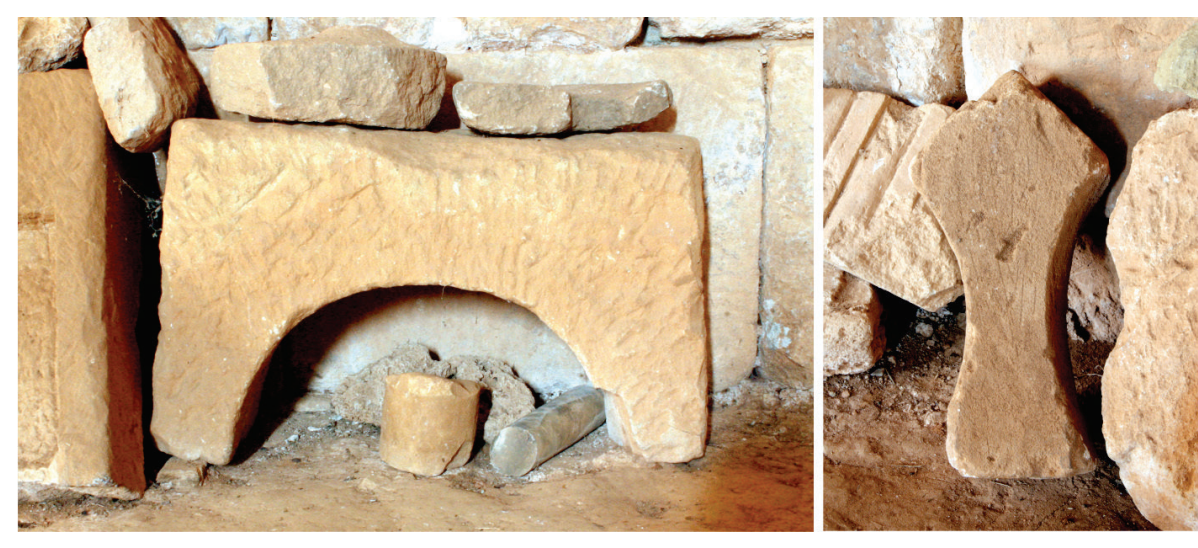

Figura 5.- Quintanilla. Dintel arcuado y salmer de arco geminado (ajimez). 
sacristías y el santuario. La zona oriental se ha supuesto de carácter monástico por su organización. El transepto asumiría la función de coro, pero también tendría la de distribuidor entre el santuario, las sacristías y las habitaciones laterales del aula. Los pasos entre el transepto y las habitaciones laterales estaban preparados para cerrar con puertas, que no se colocaron, como en la iglesia de El Trampal (Moreno 2011: 396-399; a partir de Schlunk 1971: 286).

\section{Estructura abovedada}

En el ábside (planta cuadrada, lado 3,5 m) se conservan los arranques ( $\sin$ aristas) de las pechinas de toba que se ajustan a los tres tímpanos, recortados en medio punto ligeramente peraltados, y al trasdós del arco del ábside. No se conserva ningún resto de la bóveda, probablemente baída, que fue demolida en 1925 (Figs. 2e y 6. Camps 1940: 640; Arbeiter 1990: 399).

Las alas del transepto son de planta cuadrada y del mismo tamaño que el ábside. Se cubrirían con bóvedas de cañón a su largo, sujetas y apoyadas en los testeros de las naves y en sendos arcos que rematarían su borde, de los que no se tiene ningún indicio, y que actuarían de torales con respecto al cimborrio del crucero. El ancho de sus roscas correspondería a la dimensión entre la alineación de la cara externa de los muros laterales del ábside y la interna de los de la sala central, aproximadamente igual a la rosca del arco de acceso al ábside, de modo que no tenían contrarresto por el lado del aula. Al restar a la superficie de cada ala del transepto la rosca de su arco, la planta de cada bóveda era rectangular, más corta que ancha. Las habitaciones de sacristía son también de planta y tamaño similares a los del ábside. Si admitimos el abovedamiento completo del edificio, podemos suponer que también se cubrieran con bóvedas de cañón (Utrero 2006: 151, propone armadura basándose en la ruina completa de sus muros). Todas estas bóvedas y los arcos del crucero arrancarían aproximadamente a la misma altura $(5,4 \mathrm{~m})$ que es la máxima conservada en los rincones orientales con el crucero y que coincide con el culmen del trasdós del arco de acceso al ábside y de sus pechinas. Por lo tanto, tendrían la misma altura que la bóveda del ábside (interior, 7,1 m). Podemos suponer que los arcos se construirían de piedra caliza mientras que las bóvedas serían de toba calcárea. Desconocemos la existencia de frisos de imposta, lisos, moldurados o decorados, que diferenciaran los soportes y muros de

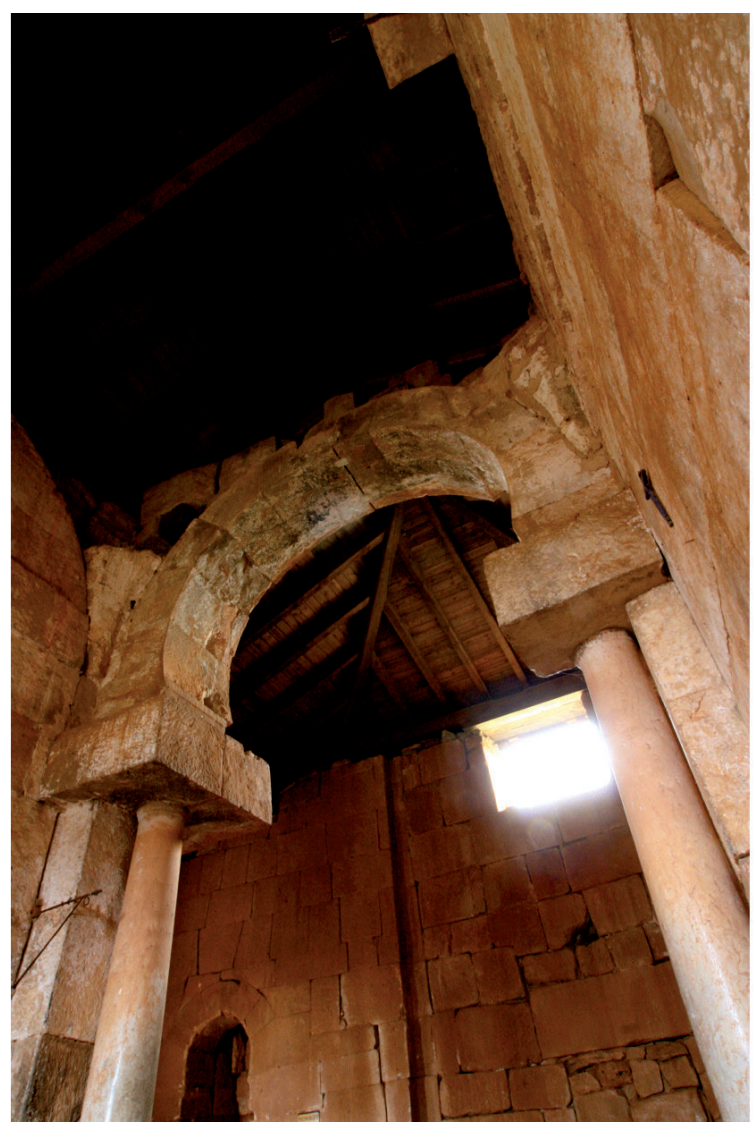

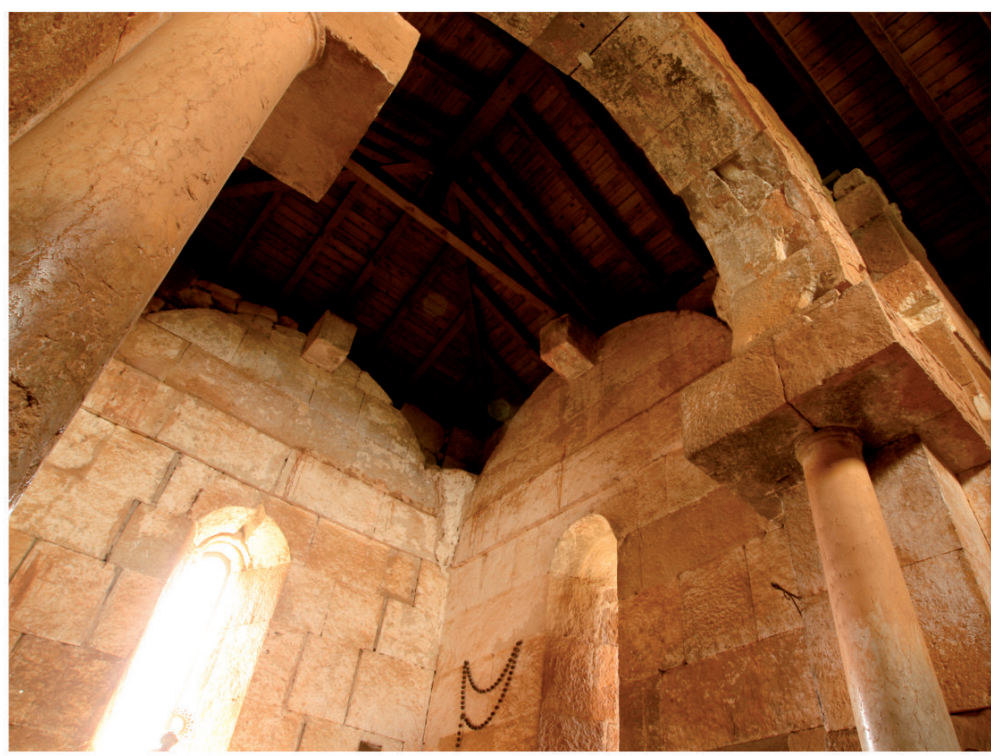

Figura 6.- Quintanilla. Interior del ábside. 
los arcos y de las bóvedas. Es posible que esta ausencia fuera una característica del grupo constructivo al que pertenece Quintanilla.

Para la separación de las naves o habitaciones laterales del aula, de la que solo se conocen sus fosas de cimentación, se proponen dos tipos de soportes: arquerías o muros; a los que corresponderían tipos de cubiertas que varían entre la armadura o el abovedamiento completo o su alternancia (arquerías: Íñiguez 1955: 80-81; Arbeiter 2001: 76-77; muros y habitaciones: Camón 1963: 216; Caballero y Arce 1997: 264; Utrero 2006: 167; armadura en el transepto y la nave central: Schlunk 1947: 301; armadura en la nave central: Palol 1956: 102; Gómez Moreno 1966: 131; Fontaine 1978: 245; duda de si armadura o bóveda en la nave central: Arbeiter 2001: 77; no es posible decidir el abovedamiento completo: Utrero 2006: 151, 165-167 y 511-512; posible abovedamiento completo: Schlunk y Hauschild 1978: 95; abovedamiento completo: Camps 1940: 642; Íñiguez 1955: 80 y 83; Caballero y Arce 1997: 264).

No se duda de que las zanjas de los espacios occidentales del aula correspondieran a muros de carga que delimitaban un porche y sendas habitaciones de esquina. En su extremo oriental quedan restos que explican cómo eran los primeros tramos de los espacios laterales, a norte y sur, de planta cuadrada. En el lado sur de la pared de cierre del transepto se conserva un tímpano y el arranque de una pechina y junto a ellos, el salmer y la primera dovela de un arco de ligera herradura sobre una pilastra adosada y desplazados estos por efecto de la ruina (Figs. 2e, 3 y 7). Este arco era el inicio del soporte longitudinal del aula y servía de apoyo a la bovedilla que cubría el tramo (sala central 9,4 m x 4,8 m, espacios laterales $8,4 \mathrm{~m} \times 1,8 \mathrm{~m}$ ). La propuesta de arquerías que separan naves propone tres tramos laterales cubiertos con bovedillas baídas o de arista y separados por dos pilastras intermedias (Fig. 8a. Arbeiter 1990 y 2001). Según esta solución, el promedio de las dimensiones da lugar a tres tramos rectangulares $(1,8 \mathrm{~m} \mathrm{x} 2,2 \mathrm{~m})$ con arcos torales o fajones intermedios sobre pilastras $(0,9 \mathrm{~m})$. Estas dimensiones contrarían las huellas que se conservan en el suelo (de las que no debemos dudar, igual que no dudamos de las restantes) y que documentan tres habitaciones, la primera de planta cuadrada y las otras dos rectangulares, separadas por tabiques intermedios $(1,8$ $\mathrm{m}, 2,1 \mathrm{~m}$ y $3,1 \mathrm{~m}$ y tabiques de $0,7 \mathrm{~m}$ ). De acuerdo con esta interpretación que depende de las huellas conservadas, las habitaciones orientales se cubrirían con bóvedas baídas o similares y las intermedias de planta rectangular lo harían con bóvedas de cañón (Fig. 8b. Caballero y Arce 1997). Las habitaciones cuadradas de esquina, laterales al porche, podrían cubrirse con cualquiera de estas bóvedas, de pechinas o cañones. El porche, si incluía una tribuna, necesitaría dos bóvedas superpuestas de cañón, como S. Miguel de Lillo (Oviedo).

La estructura resultante según nuestra propuesta corresponde a una sala central abovedada y contrarrestada por habitaciones laterales también abovedadas (Utrero 2006: 167). La bóveda de cañón de la sala estaría limitada en sus extremos por los cuerpos del crucero y del coro. Su altura de intradós la marcaría la de las bóvedas del transepto, de modo que no las superara, aunque, al

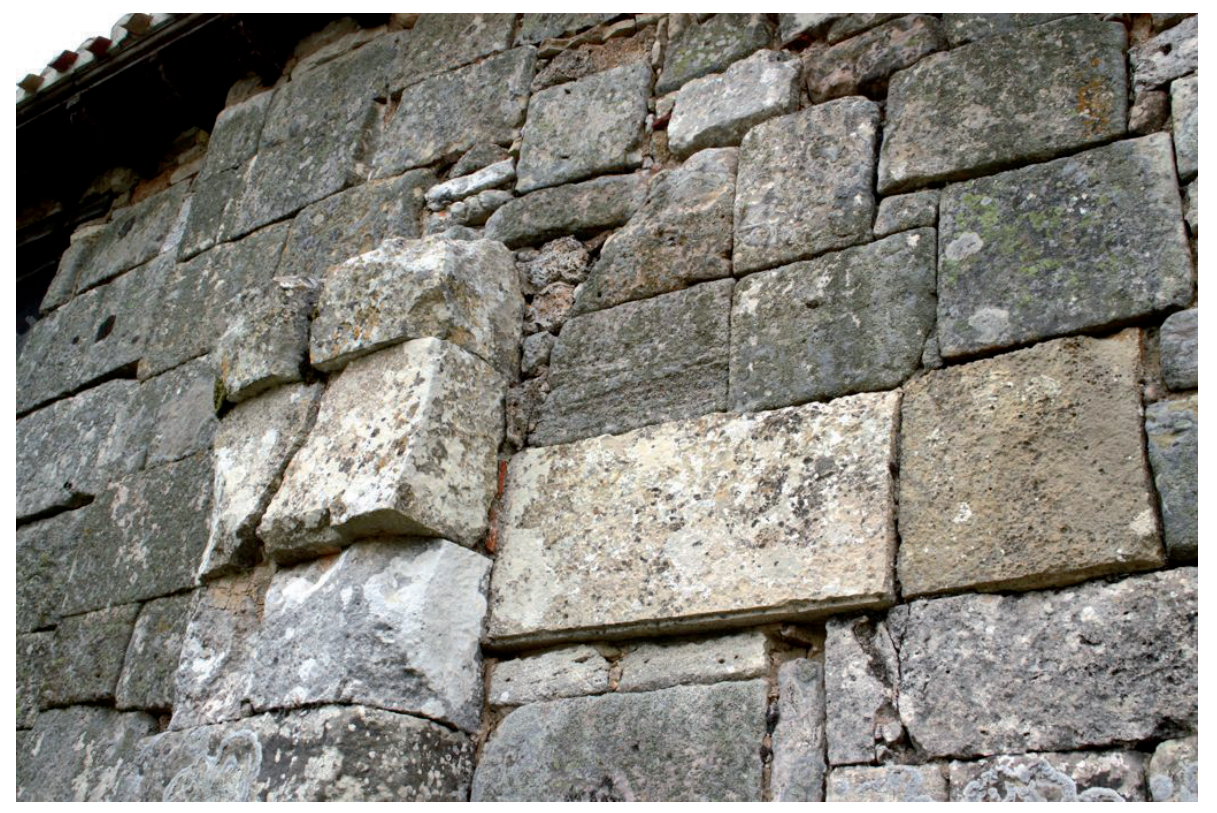

Figura 7.- Quintanilla. Detalle del frente oeste. Arranque de arco, dintel de puerta y arranque de pechina. 

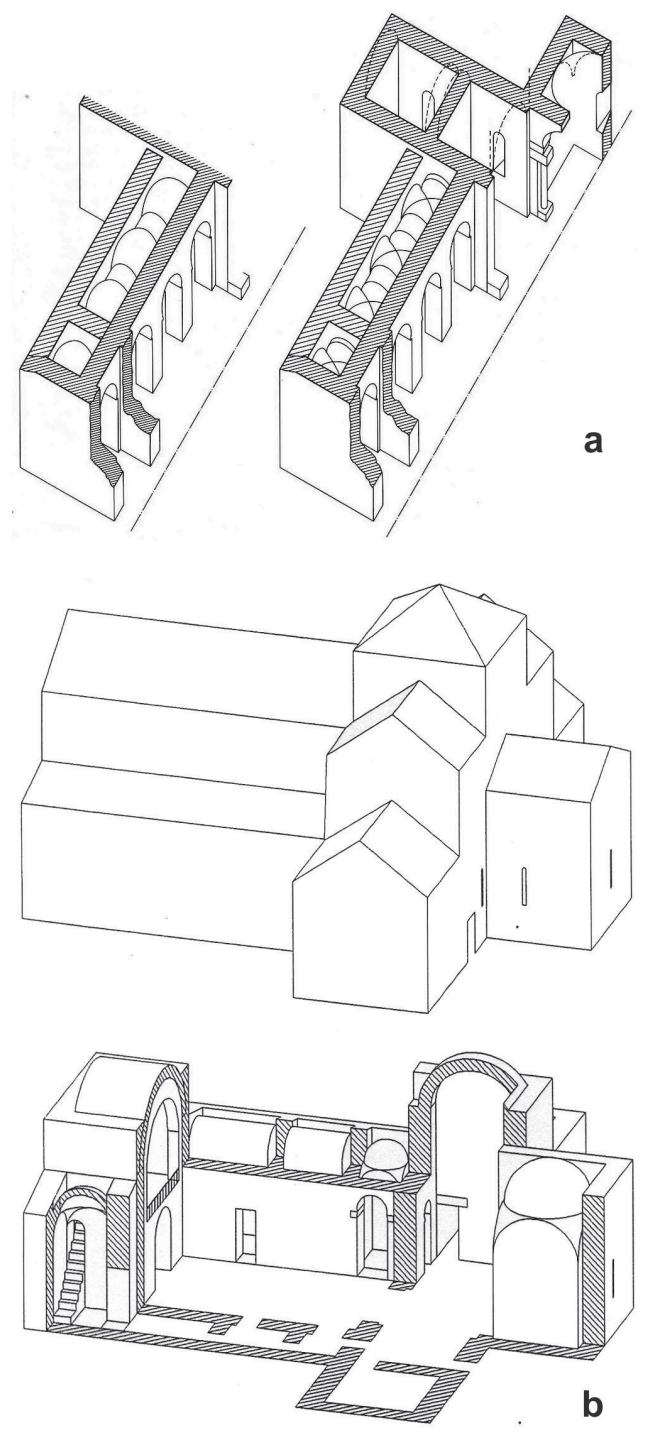

Figura 8.- Quintanilla. Reconstrucción según Arbeiter (1990) y Caballero y Arce (1997, la superior inédita).

ser mayor su luz, su arranque estaría más bajo (entre 4,8-5 m, aproximadamente la luz de la nave). La bóveda debería apoyar en el arco que daba paso del aula al crucero. Pero la diferencia entre la luz de la sala y la del arco de paso al crucero ( 5 y $3,4 \mathrm{~m}$ ), obliga a pensar en que habría un murete anular por encima del arco, de modo que sus dovelas no tuvieran una longitud extraordinaria (aproximadamente de $0,8 \mathrm{~m}$ de alto, la mitad de la diferencia entre ambas dimensiones). Aunque el hueco de paso al crucero está tapiado, se observan sus aristas y se comprueba que no hay huellas de capiteles de un arco bajo, similar al del ábside, como se ha propuesto (Arbeiter 1990: 401, 410 y 427, fig. 4, y 2001: 48, 63 y 78, fig. 36; seguido por Caballero 2013: 209-210). E1 extremo oeste de la bóveda apoyaría en otro muro en el que se abriría el vano de la tribuna (Fig. 9).
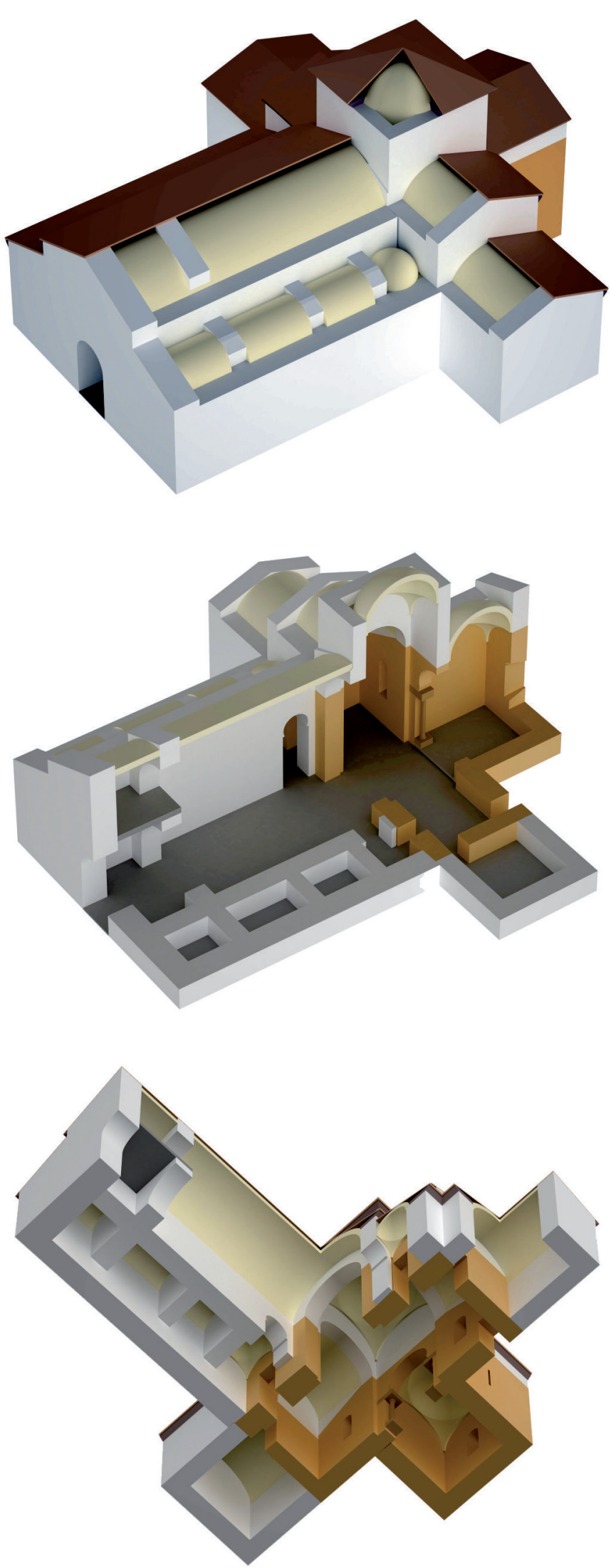

Figura 9.- Quintanilla. Propuesta de reconstrucción con crucero y cimborrio (dibujo Rafael Martín Talaverano). 


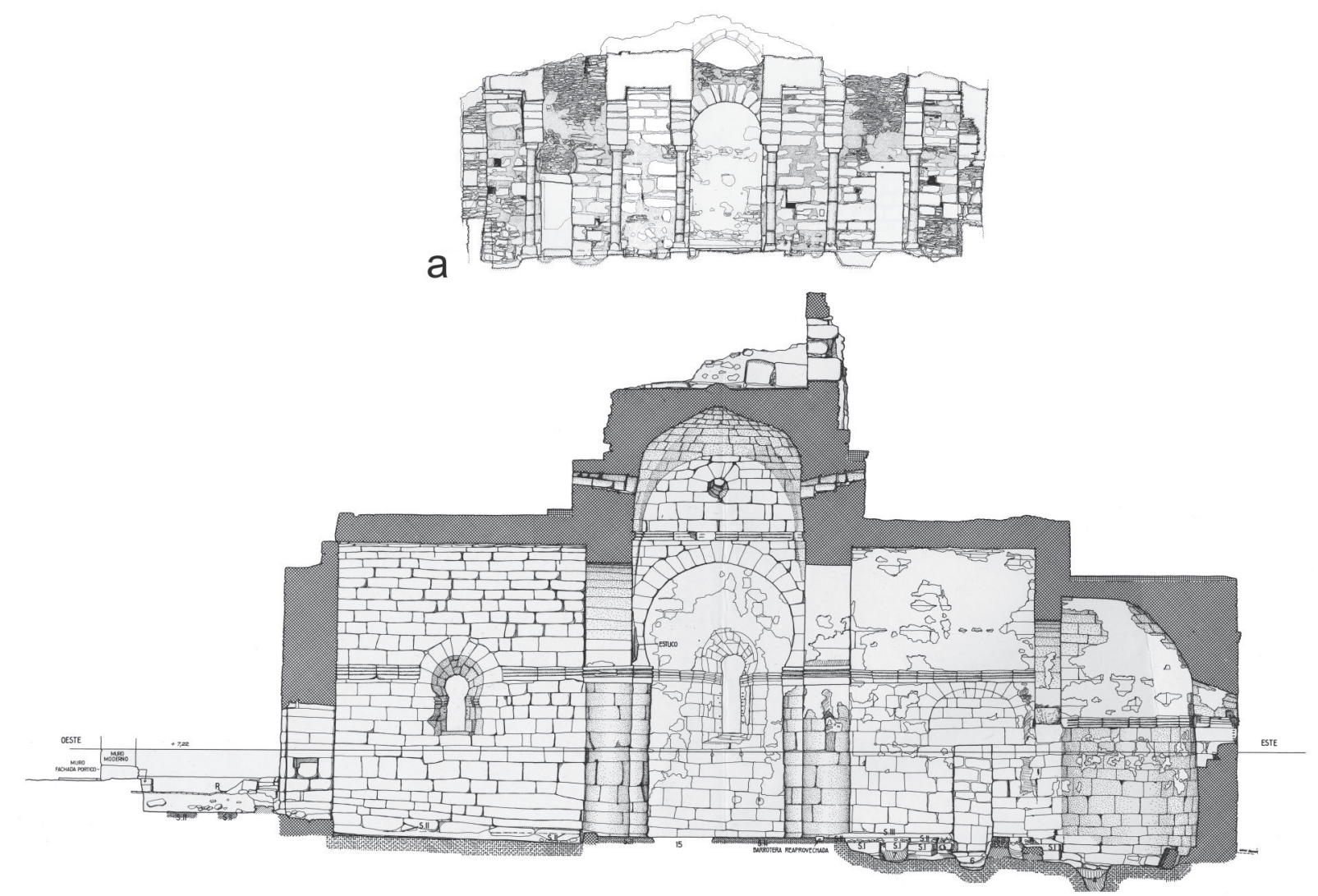

b

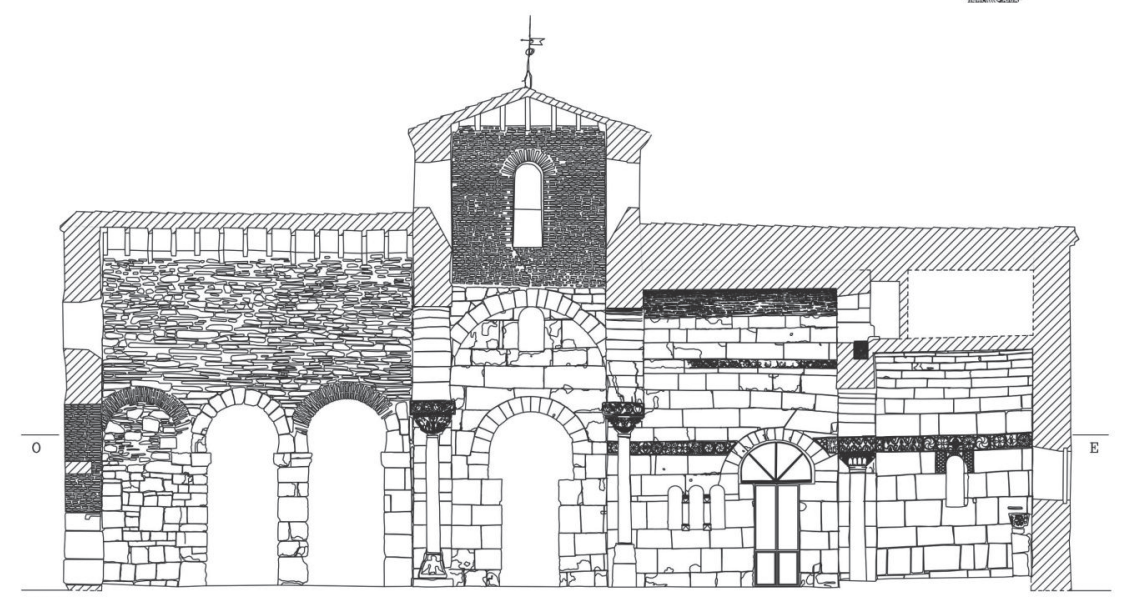

C

d

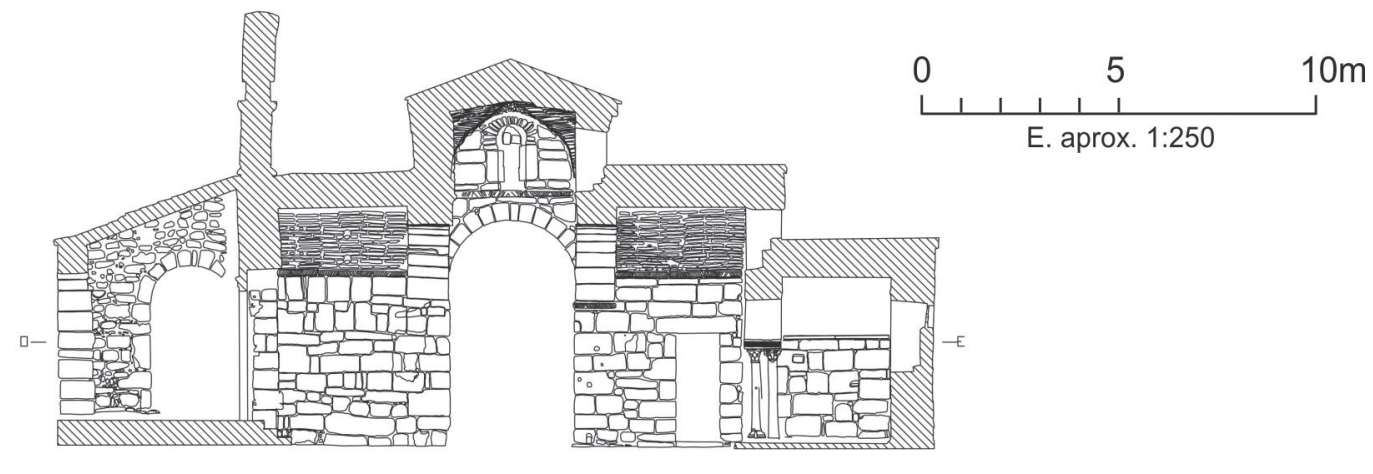

Figura 10.- Secciones de iglesias altomedievales con transepto y crucero con cimborrio abovedados. Santa Lucia de El Trampal; Santa Maria de Melque; San Pedro de La Nave; y Santa Comba de Bande. Escala 1/250 (según Caballero y Sáez 1999; Caballero y Latorre 1980; Caballero y Arce 2004; y Caballero, Arce y Utrero 2004). 

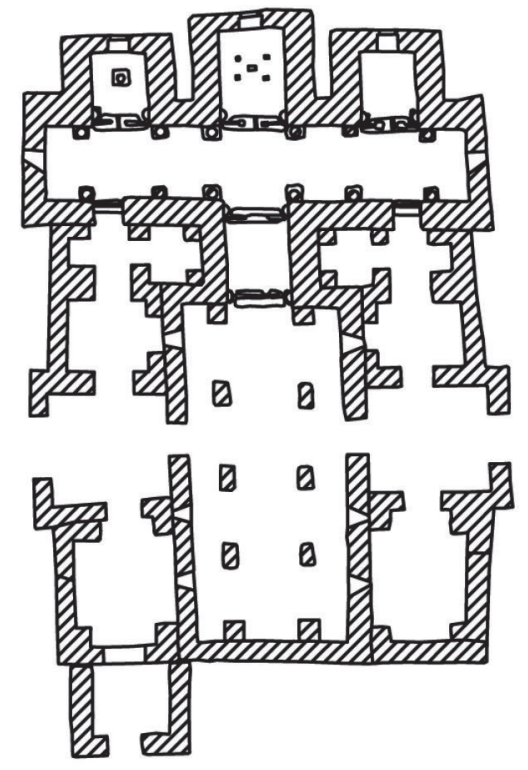

El Trampal

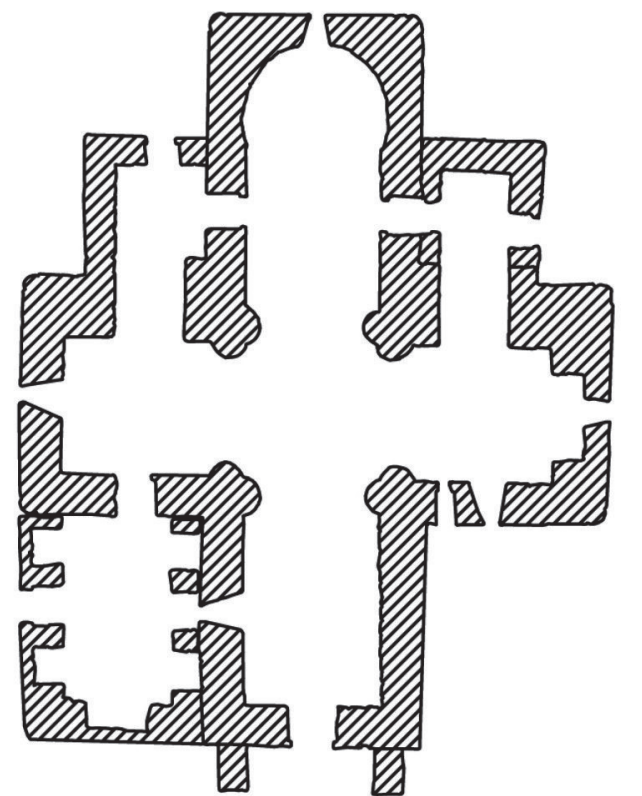

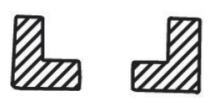

\section{Melque}

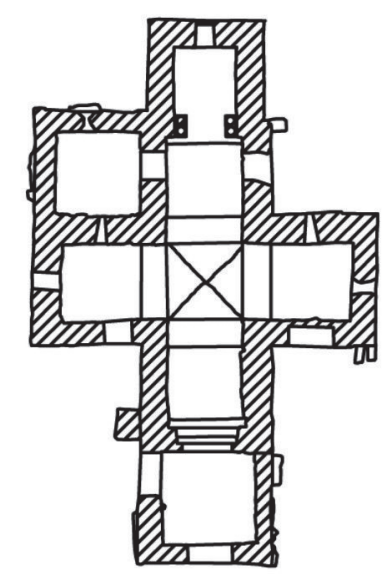

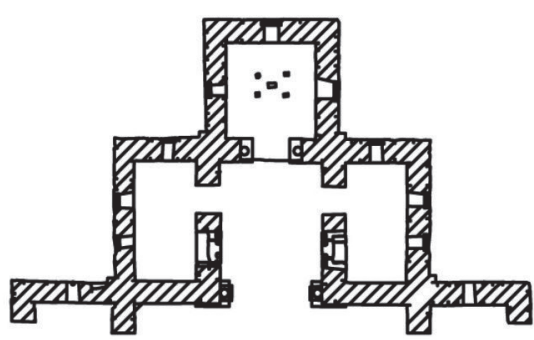

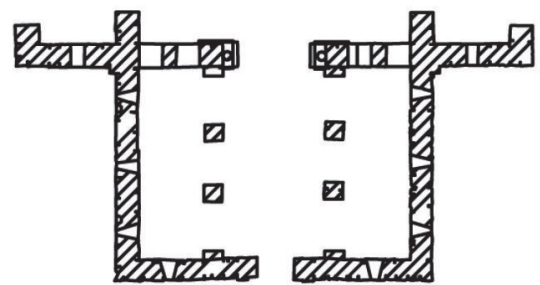

San Pedro de la Nave

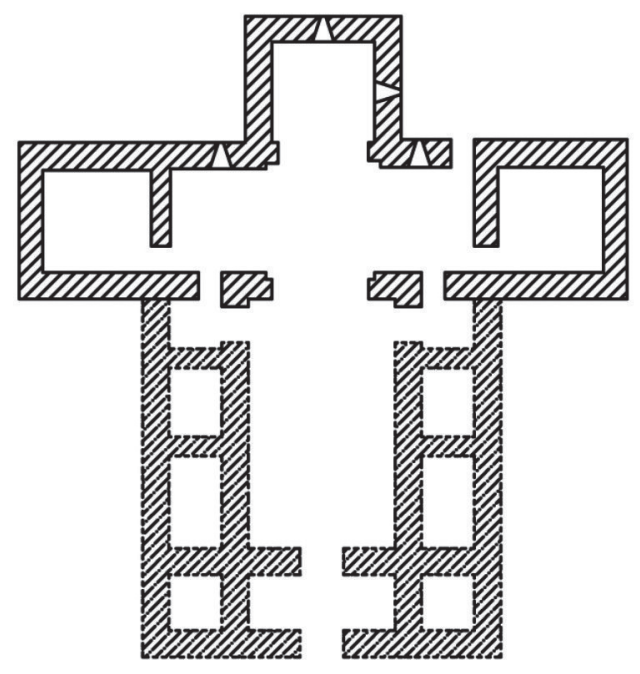

\section{Quintanilla de las Viñas}
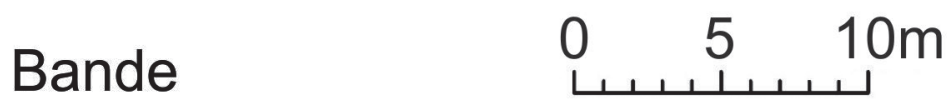

Figura 11.- Plantas de iglesias altomedievales con transepto y crucero con cimborrio abovedados. Santa Lucía de El Trampal; Santa María de Melque; San Pedro de La Nave; Quintanilla de las Viñas y Santa Comba de Bande. Escala 1/333 (dibujo Fernando Arce. A partir de: Caballero y Sáez 1999; Caballero y Latorre 1980; Caballero y Arce 2004; Arbeiter 1990; y Caballero, Arce y Utrero 2004).

Tratamos a continuación de la cubierta del crucero. La luz del ábside y de las naves laterales del transepto $(3,5 \mathrm{~m})$ es significativamente menor que la de la sala central del aula $(5 \mathrm{~m})$, lo cual obligó a estrechar el paso entre el aula y el crucero con unas antas que unificaban su luz y conseguían en el crucero una planta cuadrada $(3,8 \mathrm{~m}$ de lado), apropiada para cubrirla con un cimborrio abovedado (Fig. 9). Si suponemos que su cubierta era una cúpula sobre pechinas se necesita que los muros del crucero rematen en cuatro tímpanos o, eventualmente, arcos. Las 
pechinas de la cúpula podían descansar, a una altura más baja, directamente sobre los dos arcos que hemos supuesto en el transepto, sobre un tímpano en el muro sobre el arco del ábside y sobre el murete anular sobre el arco de la sala del aula. Esta solución, mazacote pero estable, sería una excepción con respecto a las del grupo de iglesias con transepto y cimborrio, al que pertenece Quintanilla, que elevan el cimborrio con tímpanos levantados sobre los torales. Siguiendo esta solución habitual, las enjutas de los arcos estarían rellenas hasta el remate de los trasdoses, nivel al que arrancarían los tímpanos; sobre los tímpanos, apoyarían las pechinas; y sobre las pechinas, una cúpula semiesférica o continuarían sus superficies con una baída. La altura interior de esta solución elevada con tímpanos y cúpula semiesférica llegaría a los $11 \mathrm{~m}$ (similar a la de Melque); la altura de la solución baja, sobre tres arcos, se quedaría en 9,25 m. En ambos casos, estas medidas se reducirían aproximadamente un metro si la iglesia en vez de rematarse con pechinas y cúpula semiesférica lo hiciera con bóveda baída, que en cambio provoca más empuje. En cualquiera de ambas soluciones se debe valorar el material de toba calcárea empleado y la estructura de pechinas que reducirían su peso y sus empujes y aumentarían la estabilidad (Utrero 2006: 165-166).

La solución (salvo las variantes señaladas) es similar a la utilizada en el grupo de iglesias cuya estructura está preparada para transepto y crucero con cimborrio abovedados: Santa Lucía de El Trampal (prov. Cáceres, incompleta), Santa María de Melque (prov. Toledo), San Pedro de La Nave (prov. Zamora, restaurada) y Santa Comba de Bande (prov. Orense, abovedada de ladrillo), además de Quintanilla (arruinada). En este grupo, muros corridos soportan las bóvedas del transepto de modo que, cuando el aula es de tres naves (El Trampal, La Nave y Quintanilla), los extremos orientales de sus naves laterales, que dan al transepto, se cierran por esos muros. Pese a ello, estas iglesias presentan notables diferencias entre sí. Ni sus proyectos ni sus talleres constructivos fueron los mismos, ni ellas son estrictamente coetáneas; pero forman parte del mismo ambiente técnico altomedieval y comparten esta solución (Figs. 10 y 11. Caballero y Sáez 1999; Caballero y Latorre 1980; Caballero y Arce 2004; Caballero, Arce y Utrero 2004; Utrero 2006).

La existencia de una bóveda en la sala central de Quintanilla se había planteado como imposible porque su luz $(5 \mathrm{~m}$ ) supera el límite que se considera normal para una bóveda de su época. Y porque sus muros y las estructuras laterales no contrarrestarían sus empujes. Pero, bien mirado, estas son las causas que podrían confirmar que la sala estaba abovedada y que sus empujes provocaron la ruina. Los restos conservados del edificio presentan una ruptura por su eje que se refleja en las grietas en el testero del ábside y en los muros orientales de las naves del transepto y en los vuelcos hacia afuera de los testeros del transepto. Sorprende la supervivencia de las antas o jambas del paso entre la sala del aula y el crucero, que soportaban el arco toral occidental del crucero y los empujes laterales de los arcos torales norte y sur, contrarrestados de modo imperfecto. El empuje y la ruina de la bóveda de la sala, de luz exagerada e incorrectamente descargada por las habitaciones laterales, arrancó los muros de separación de las habitaciones del aula sobre los que se asentaba. Estos a su vez arrastrarían parcialmente el muro oeste del transepto en que apenas estaban anclados, como demuestra el

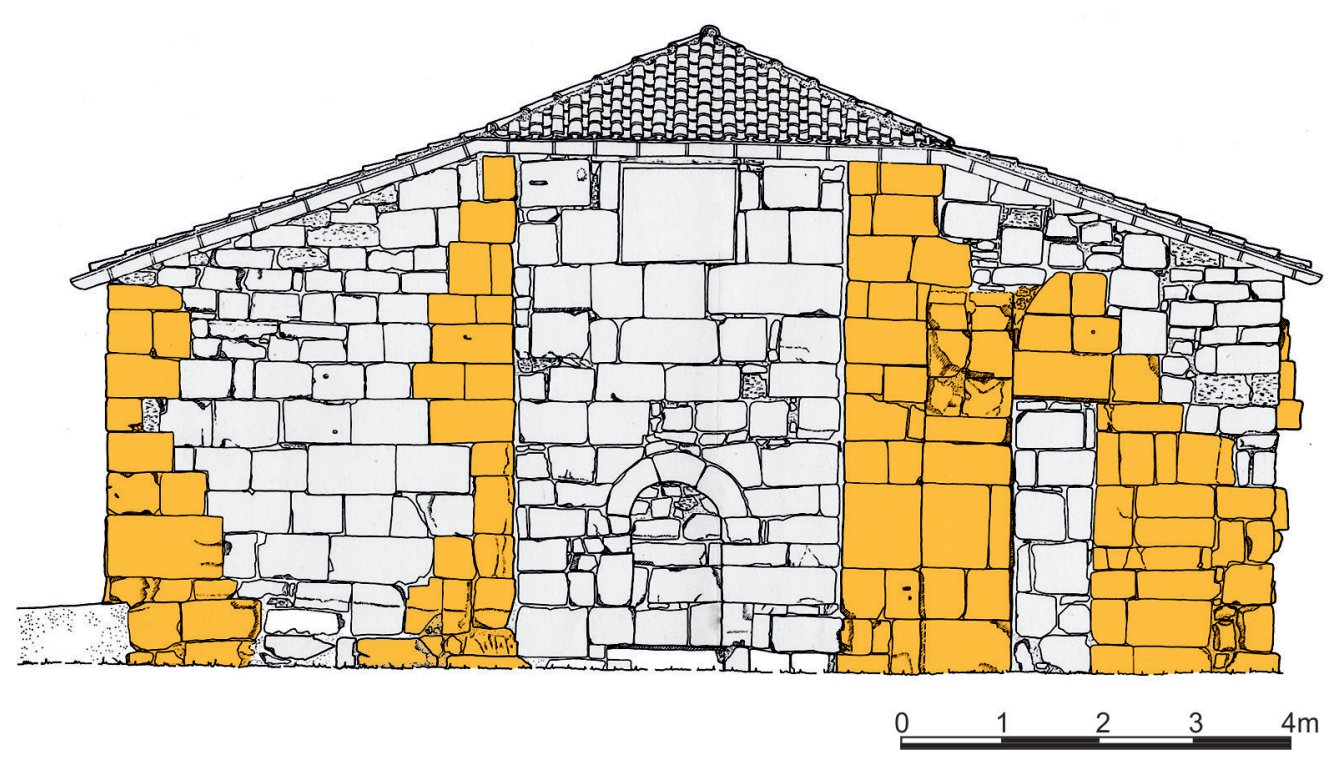

Figura 12.- Quintanilla. Alzado oeste, restos correspondientes al edificio originario. Escala 1/100 (tratamiento de Fernando Arce sobre plano de Arbeiter 1990). 
fuerte movimiento que presentan el salmer y la primera dovela supervivientes en su zona meridional. Consecuentemente se arruinarían los muros perimetrales del aula y las bóvedas del transepto (Fig. 7 y 12). El cimborrio, estable y mejor compensado, se arruinaría sobre sí mismo sin afectar a sus esquinas y a las antas (como ocurrió en el ábside con menos daño). La zona de la fachada oeste pudo resistir, al estar arriostrada por la tribuna, pero aislada del edificio y, por tanto, sin función.

La ruina debió producirse enseguida dado que el solar fue ocupado por una necrópolis de plena Edad Media (Íñiguez 1955: 81). En la segunda mitad del s. XIV, la ruina obliga a que Andrés, abad de Arlanza, traslade los restos de familiares de Fernán González (Huidobro 1927: 213).

La solución abovedada que defendemos se basa en la estructura del edificio y en la ruina que sufrió, aunque sus detalles no son seguros.

\section{Decoración esculpida}

La decoración de la iglesia de Quintanilla se distribuye en dos grupos, exterior e interior (Schlunk y Hauschild 1978; Andrés y Abásolo 1982). El grupo exterior decora los muros del ábside y el transepto con tres frisos incompletos (Fig. 2a; alto $45 \mathrm{~cm}$ ). Los frisos superior e intermedio figuran cintas entrelazadas y sogueadas formando círculos tangentes. El superior encierra figuras de toros, grifos, carnívoros y ciervos entre motivos vegetales. El intermedio, en el testero del ábside, encierra rosetas que en el lado norte se alternan con tres monogramas, quedando en el lado sur los huecos preparados para otros monogramas que no se tallaron.

\section{fanl. et danl. $f(e) c(e) r(u) n(t)$}

Los monogramas, cuya lectura se ha intentado sin éxito, no debían referirse a donantes, pues Flámola consta como oferente a nuestro parecer inscrita simultáneamente en el interior del edificio. Este friso continúa con pavones y gallináceas alternando con "árboles de la vida". El friso inferior se decora con roleos que encierran palmetas y racimos. La talla de los tres frisos se interrumpió cuando aún no estaba terminada, lo que indica que los sillares se decoraron cuando ya estaban colocados en obra y de modo que cada motivo se iba completando por orden y de modo independiente (Fig. 13).

El grupo interior se concentra en el arco del ábside. La arquivolta se decora con roleos con palmetas y racimos y gallináceas. Los frentes de los cimacios/
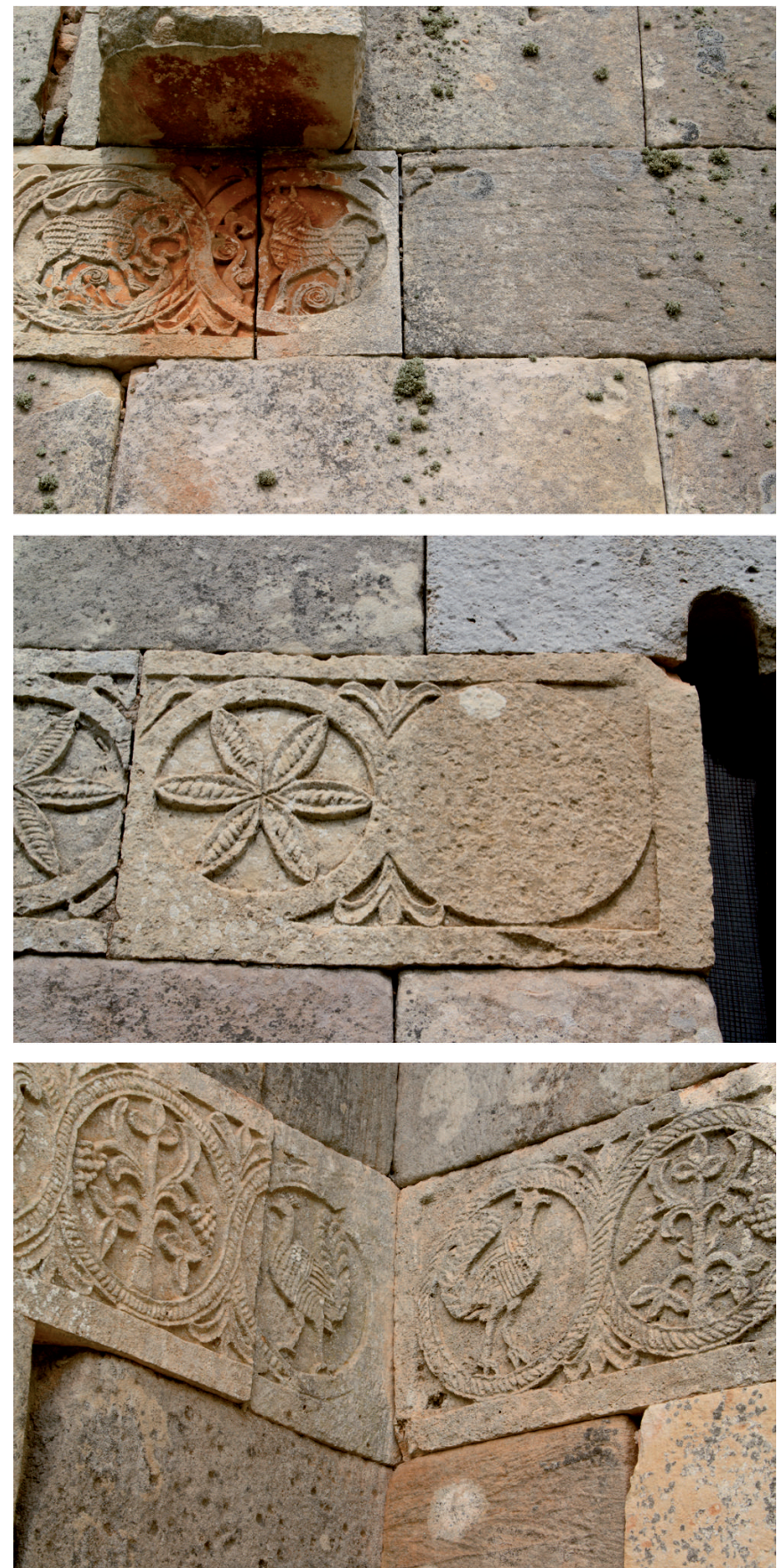

Figura 13.- Quintanilla. Detalles de frisos exteriores del ábside, superior, medio e inferior, con decoración inacabada.

capiteles lo hacen con relieves con ángeles con aureola (perdido uno en el capitel norte, roto) que sostienen sendos tondos con bustos masculinos, el norte coronado con un creciente y el sur coronado con rayos y con la presencia de una palma y una lira caídas, con las respectivas inscripciones Lvna y Sol (Fig. 14). Las escenas se pretenden enmarcar con una doble moldura. En el borde superior del capitel sur la moldura se interrumpe por una inscripción que dice (del Hoyo e.p., lectura): 


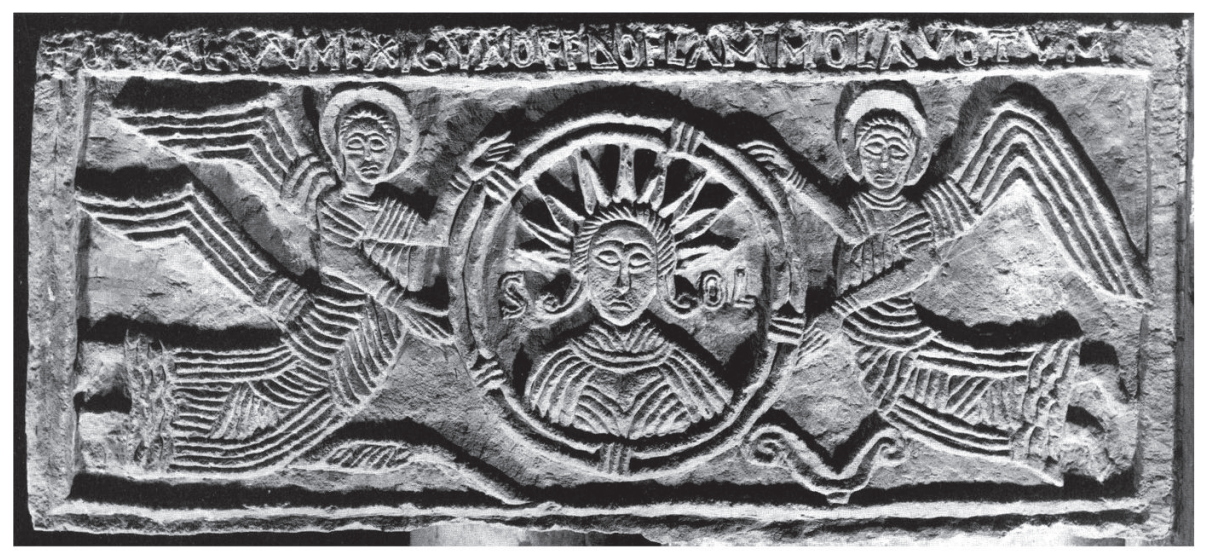

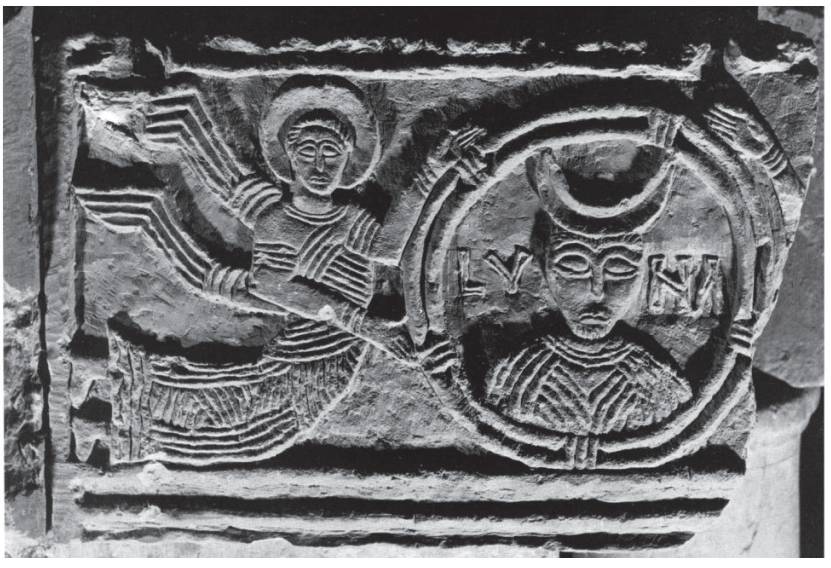

$\dagger$ oc exiguum exigua off(ert) D(e)o Flammola votum

(Cruz. Este modesto voto ofrece a Dios la humilde Flámola)

Los bordes laterales distales de ambos sillares quedaron como un listel liso, al no tallarse la moldura porque las jambas del arco impedían la labor del tallista. También quedó el listel liso entre la inscripción y el rincón, sin que se pudiera repartir la inscripción a todo el largo del marco, ni tallar la doble moldura en ese espacio. Estos detalles indican que las decoraciones se hicieron, igual que las del exterior, cuando los sillares, lisos, ya estaban colocados en su sitio.

Entre las piezas sueltas, una pareja de sillares es similar a los capiteles del ábside y pertenece al mismo grupo decorativo interior. Sus frentes se decoran con sendos bustos, masculino y femenino, acompañados de ángeles, que se supone representan a Cristo y la Iglesia o a los oferentes, en este caso con todos sus marcos moldurados (Schlunk y Hauschild 1978: lám. 148. Museo de Burgos. Las dimensiones de los cuatro capiteles son similares, variables entre $39 / 46 \mathrm{~cm} \mathrm{x} \mathrm{90/98} \mathrm{cm} \mathrm{x}$
Figura 14.- Quintanilla. Impostas/capiteles del ábside, sur y norte (según Schlunk y Hauschild 1978).
$51 / 62 \mathrm{~cm}$ ). Como ya dijimos, no se pudieron colocar en el vano entre el aula y el crucero. Una ubicación alternativa pudo ser el arco exterior del porche, cuya altura sería similar a la del arco del ábside y que no tendría cierres.

En el edificio hay otros pequeños sillares, unos decorados y otros lisos quizás preparados para decorar. En la cara exterior del testero del ábside se encuentran tres de ellos resaltados y lisos. Otro también resaltado se encuentra encima de la clave del arco del ábside, decorado con un busto de Cristo barbado, coronado con una cruz y en actitud de bendecir (Fig. 2a y b). Otros dos sillares similares, sueltos, representan bustos de evangelistas con un libro en la mano que, por su significado iconográfico, podrían haberse situado en el crucero ${ }^{1}$ (Schlunk y Hauschild 1978: lám. 150). Se conocen doce piezas más de friso, sueltas, que se consideran procedentes de la iglesia a las que nos referimos más adelante. Seis de ellas se decoran con roleos similares a los del friso correspondiente del grupo exterior de la iglesia, aunque presentan variantes

\footnotetext{
Robados el día 7 de agosto de 2004
} 
de dibujo que achacamos a una mano o tallista distinto. Son de piedra caliza, dos de buena calidad que admite pulido y el resto porosas. Su escasa profundidad, con forma de losa, supone una variedad del aparejo distinta a la que ofrecen las ruinas conservadas (dos proceden del pueblo de Quintanilla. Osaba 1952: 35 y 1954: 150-151; Ordax y Abásolo 1982: lám. 22, excepto la pieza inferior. Dimensiones similares, variables entre alto $39,5 / 47$, profundo $10 / 13,5 \mathrm{~cm}$ ).

La iglesia no ofrece indicios de impostas, lisas, molduradas o decoradas, que marquen los arranques de arcos y bóvedas lo que, de confirmarse, se puede considerar una característica propia de esta iglesia (Caballero 2013: 209). Solo otro pequeño fragmento suelto, decorado con una onda de roleo con racimo, que citamos más adelante, por su menor altura que los frisos podría pertenecer a una imposta de las bóvedas de cañón. No tuvieron esta función de impostas las primeras hiladas de los tímpanos del ábside de Quintanilla que están resaltadas o ligeramente almohadilladas con biseles. Hiladas semejantes se repiten en el transepto, alternando con otras rasantes, en un reparto asimétrico y sin una función estructural ni tampoco claramente decorativa, dado que la decoración de la iglesia es en bajorrelieve.

Del altar se conocen dos pilares de mármol, prismáticos con base moldurada y decoradas sus caras con cruces patadas con alfa y omega y con palmeras con racimos de dátiles, y un fragmento de tablero moldurado y con trifolios en las esquinas. Su estilo decorativo es el mismo que el de los frisos y el del arco del edificio. El tipo del altar se diferencia del de los siglos VI-VII por la forma del pilar, la decoración, la técnica y la producción no estándar (Sastre 2013: 147-149 y 326-329). No existen indicios de canceles (Caballero 2013).

\section{OTRAS IGLESIAS CON ÁBSIDES CON CÚPULAS SOBRE PECHINAS}

Estudiamos a continuación las demás iglesias del grupo, agrupándolas por sus caracteres formales y constructivos (Fig. 15 a 17).

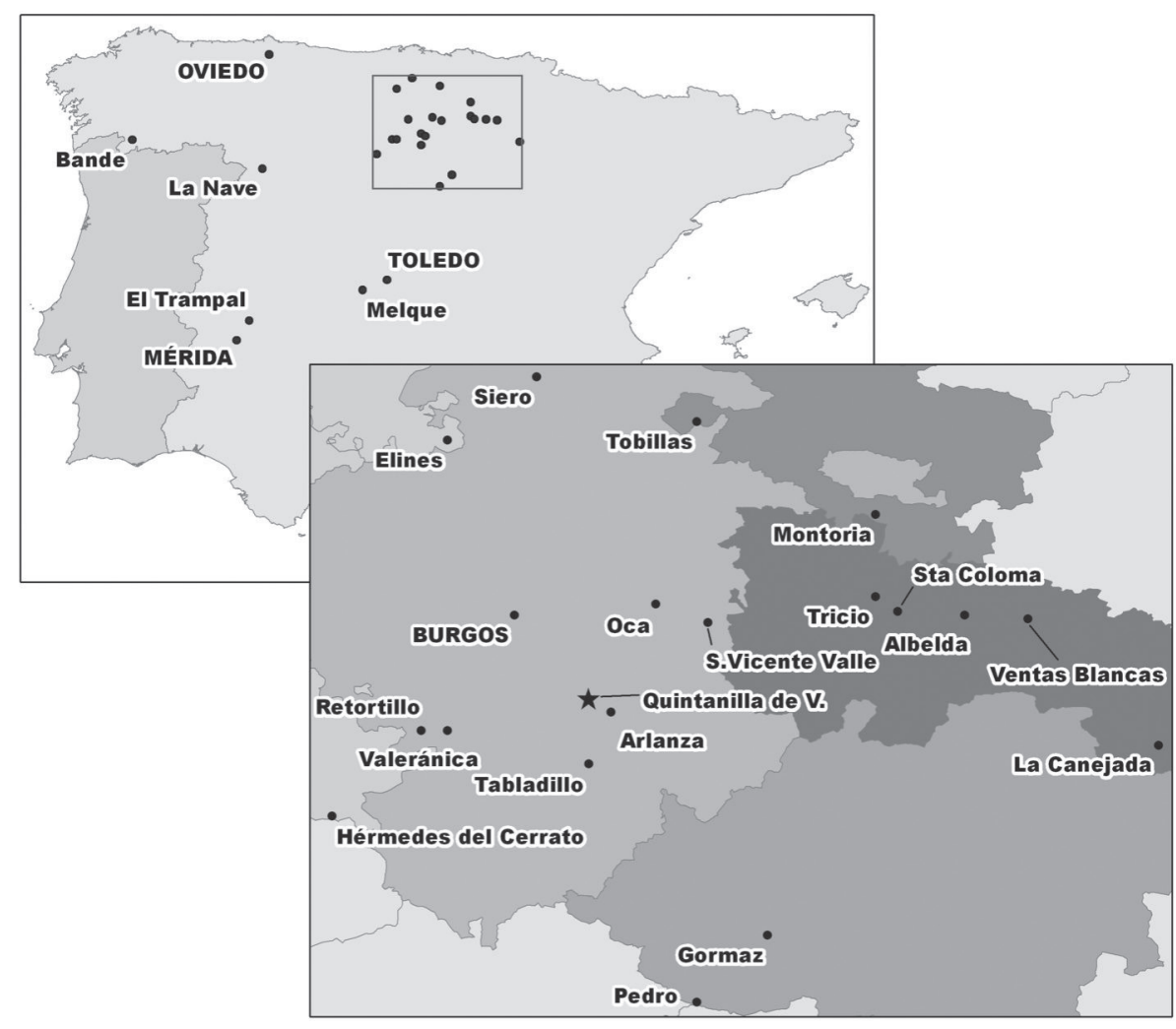

Figura 15.- Mapa con la situación de los principales lugares citados en el texto (según Jesús Caballero García). 

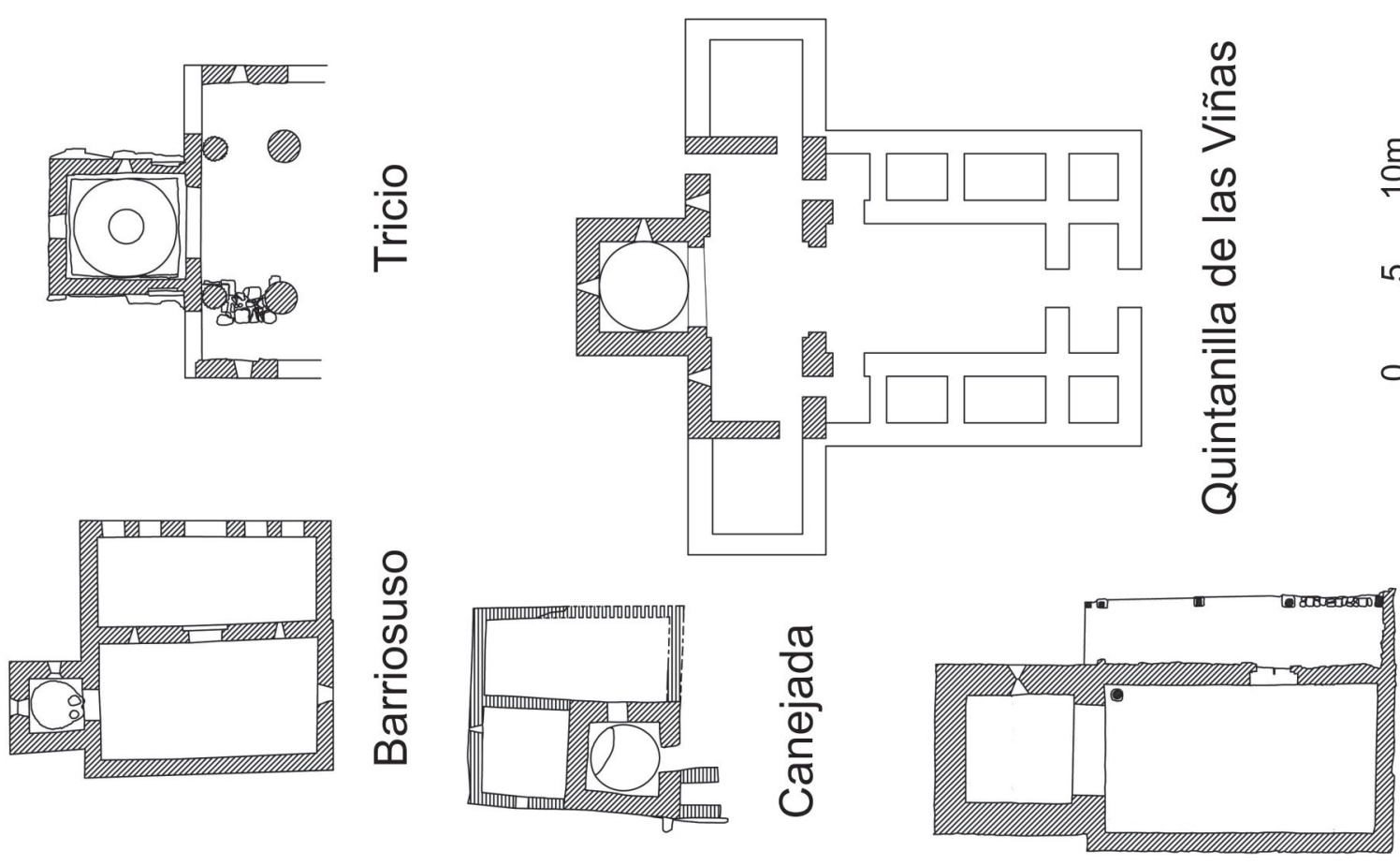

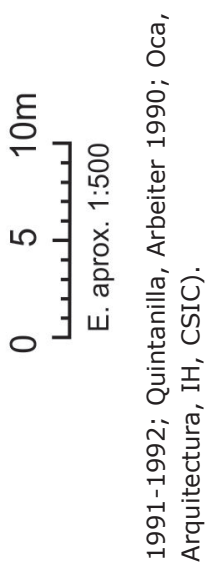

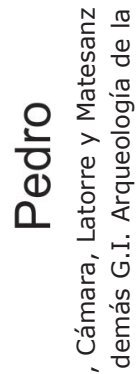
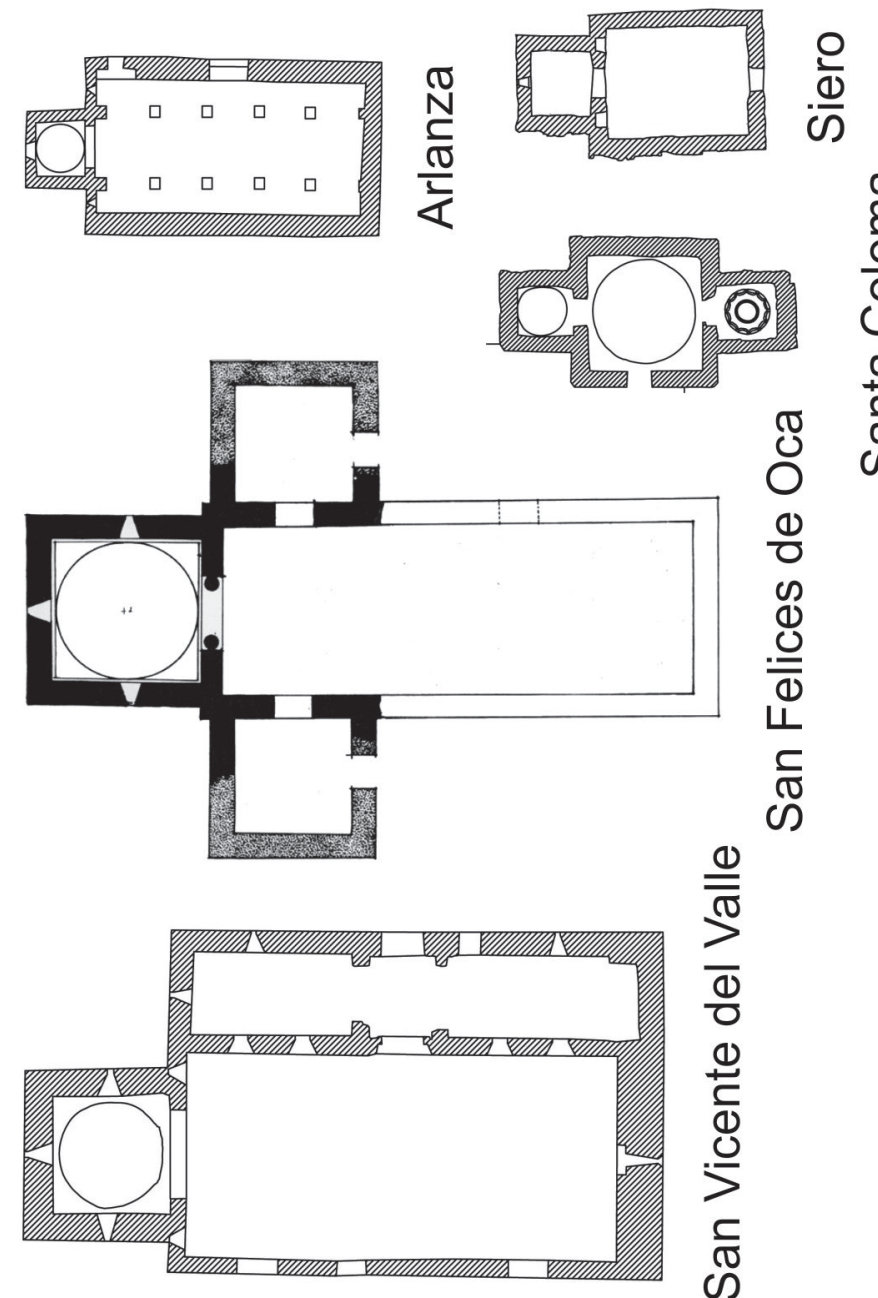

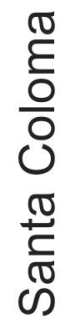

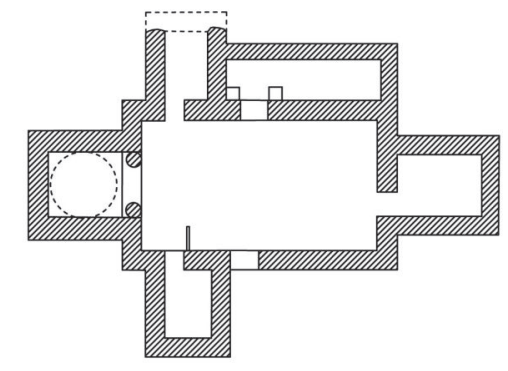

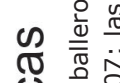

它

$\frac{\pi}{\mathrm{T}}$

$\overline{\mathbf{m}}$

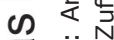

(T)

$\stackrel{\frac{C}{(1)}}{>}$

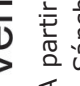

రั

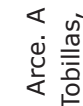

$\frac{1}{0}$

क

心
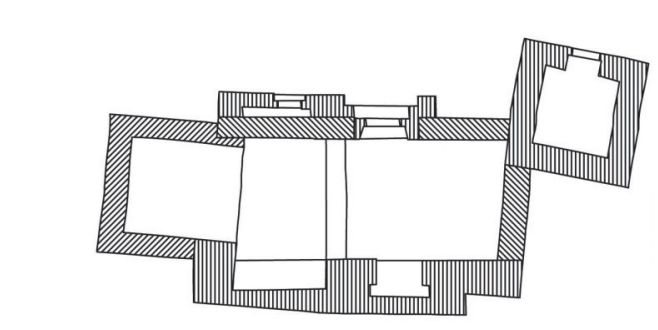

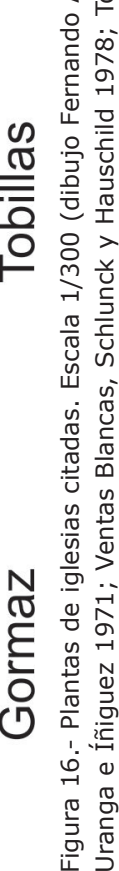




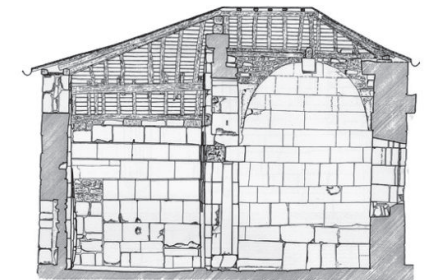

Quintanilla de las Viñas

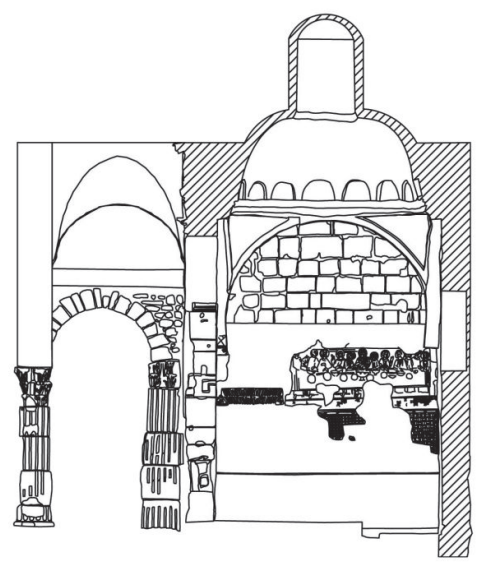

Tricio

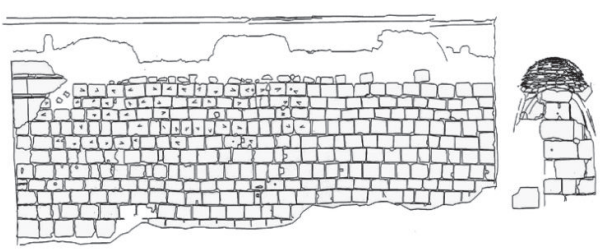

Arlanza

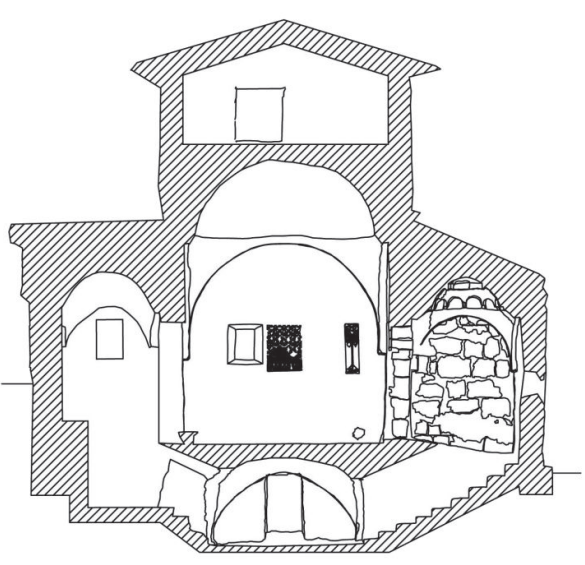

Santa Coloma

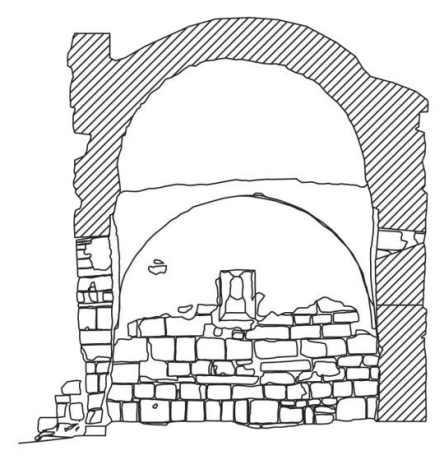

San Felices de Oca

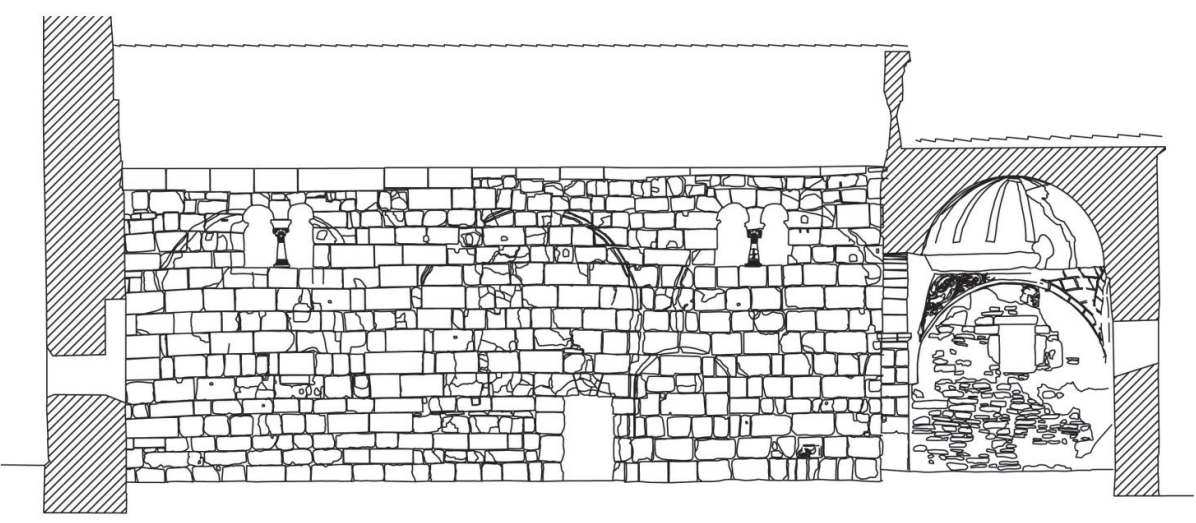

San Vicente del Valle

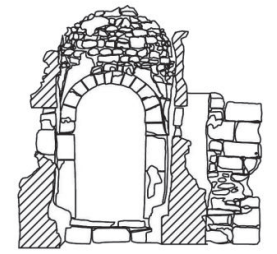

Ventas Blancas

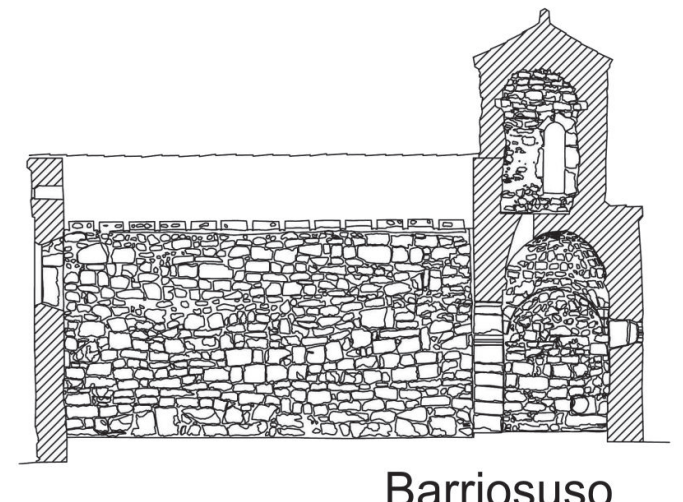

Barriosuso

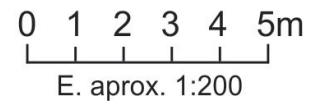

Figura 17.- Secciones de iglesias con ábside con bóveda baída. Escala 1/200 (Según: Quintanilla, Arbeiter 1990; Arlanza, Caballero, Cámara, Latorre y Matesanz 1991-1992; las demás dibujo de Fernando Arce, G.I. Arqueología de la Arquitectura, IH, CSIC). 


\section{Posibles iglesias abovedadas. Oca, Ventas Blancas y Arlanza}

Estas tres iglesias presentan algunos indicios que permiten discutir si estuvieron abovedadas por completo, lo que solo se puede asegurar de las de Quintanilla y Santa Coloma, de tipo arquitectónico y estructura muy distintos.

San Felices de Oca (Villafranca de Montes de Oca, prov. Burgos. 25,6 $\mathrm{m} \times 18,3 \mathrm{~m}$ ) sólo conserva en pie el ábside (Huidobro 1928-29; Uranga e Íñiguez 1971; Sacristán de Lama 1991-1992, excavación inédita; Utrero 2006: 167-169, aula abovedada). El material de sus piezas es de expolio, sillares (arenisca), dovelas (caliza blanca) y fustes (mármol). El aparejo es de doble hoja de sillería con relleno de hormigón, presentando abundantes codos, hiladas onduladas y desdobles. La bóveda es de piedra toba caliza extraída de cantera superficial.

Estaba formada por un aula, un gran ábside ligeramente más estrecho $(6,45 \mathrm{~m} \mathrm{x} 7 \mathrm{~m}) \mathrm{y}$, en los extremos de sus muros laterales, sendas habitaciones sobresalientes (sacristías). El acceso principal se efectuaba por un arco abierto en la fachada sur. El arco del ábside, de ligera herradura con salmeres y primeras dovelas enjarjadas y el resto trasdosado, se apoyaba sobre fustes con sillares actuando de basas y una cornisa romana y una imposta sencilla, de capiteles (Fig. 18). Están documentadas las puertas de las sacristías, con arcos de medio punto, similares al del ábside, que descargan dinteles. Sólo se conocen las ventanas del ábside, una en cada paño, saeteras y al exterior con arquito de medio punto labrado en dintel. El ábside se cubre con pechinas que arrancan con aristas y vuelan un anillo sobre el que se apoya la cúpula. Para asegurar su estabilidad, dado el tamaño de la planta, se rebajó proporcionalmente la cota de arranque de las pechinas. Al parecer, en el s. XVII, el aula (ancho 6,3 m) se cubría con bóveda de piedra toba (Uranga e Íñiguez 1971: 37-38). Aunque el grueso de muros $(0,9 \mathrm{~m})$ lo pueda avalar, el abovedamiento parece excesivo por su luz (metro y medio mayor que la nave central de Quintanilla) y la ausencia de contrarrestos. En la habitación sur se documenta el arranque de una bóveda de cañón de piedra toba, encastrada en su testero, de directriz transversal al edificio.

La iglesia de Santa María de Ventas Blancas (La Rioja. 17,1 m x 12,6 m. Martín Bueno 1973, excavación inédita; Schlunk y Hauschild 1978; Heras 1983; Utrero 2006: 168-169, aula abovedada) también se construyó con material reutilizado, salvo la toba de la cubierta de
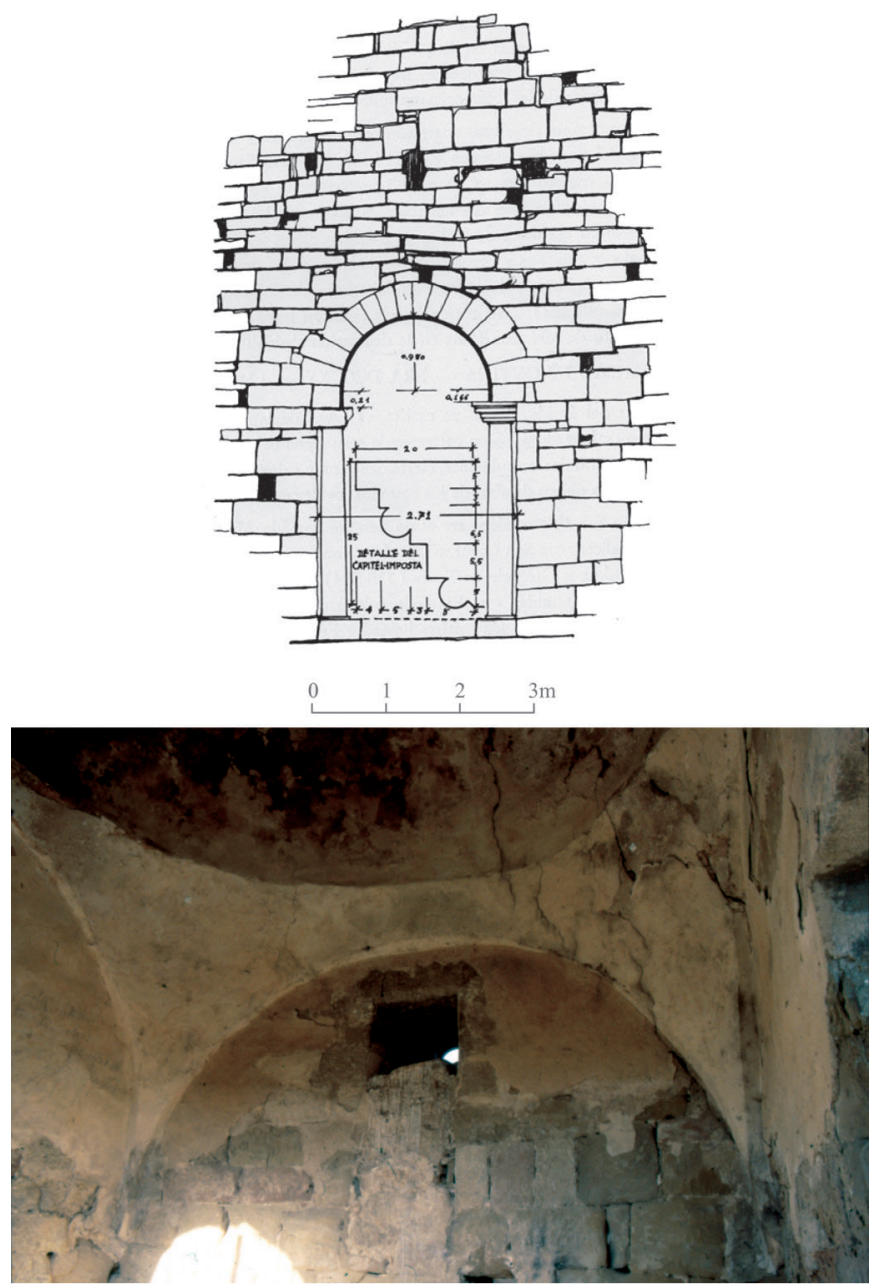

Figura 18.- San Felices de Oca (Villafranca de Montes de Oca, prov. Burgos). Alzado del acceso al ábside (según Uranga e Íñiguez 1971) y detalle de la bóveda.

su ábside. Su planta es de apariencia similar a Quintanilla y Oca, aula con ábside cuadrado y dos habitaciones delanteras, laterales al aula (sacristías). De la cúpula únicamente se conservan dos pechinas y parte del casquete (Fig. 19). Tuvo además un espacio occidental sobresaliente, más estrecho que la nave y del que se desconoce la función, y un porche meridional. Se documenta que a mediados del s. XII perteneció al monasterio cisterciense de Santa María de Ruete, momento al que se adscriben algunos añadidos, pero no existe un análisis del edificio que defina su secuencia. El arco del ábside es de ligera herradura, con dos losas profundamente empotradas que actúan de imposta/capitel, mientras que el resto del arco está trasdosado. El aula, por su luz (ancho interior 4,8 m), pudo cubrirse con una bóveda de cañón, aunque la falta de contrarrestos y el grueso de los muros $(0,7 \mathrm{~m})$, de sillería (arenisca) de dos hojas con piezas de atado, hace dudoso que lo estuviera. 


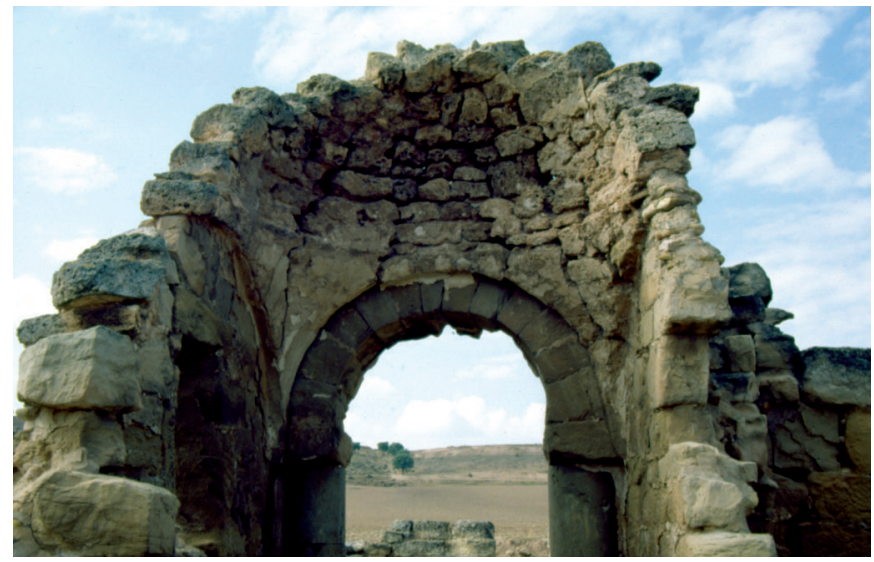

Figura 19.- Santa María de Ventas Blancas (prov. La Rioja). Ruina del ábside hacia oeste.

La fase originaria de la iglesia de San Pedro el Viejo de Arlanza (o San Pelayo, Burgos) se diferencia de las anteriores por su planta sencilla de aula con ábside (16,9 m x 7,6 m. Caballero, Cámara, Latorre y Matesanz 1991-1992; Caballero y Cámara 1995; Utrero 2006: 168-169, aula no abovedada). El material de su sillería es reutilizado (inscripciones romanas), de piedra arenisca para los cimientos y caliza para los muros; y procedente de cantera superficial las piezas de piedra toba de la bóveda del ábside (Fig. 20). Los muros laterales y el testero occidental del aula son de dos hojas, sin relleno ni sillares pasantes (igual que Quintanilla; $0,95 \mathrm{~m}$ ), mientras que el testero oriental y los del ábside son de una hoja $(0,47 \mathrm{~m})$. A pesar de su talla con regla, el aparejo es regular, con escasas cuñas y desdobles e hiladas de ligera ondulación. Las caras de los sillares se recortan, con guías de careado, al exterior, mientras que por dentro se dejan irregulares cubriéndose con una gruesa capa de estuco que quizás estaba decorado. Se diferencian sillares de módulo mayor y rectangulares, en la parte baja, de otros menores y cuadrados con mechinales a continuación; que se supusieron de dos fases pero cuya solución constructiva pertenece a la misma fase originaria.

El aula tenía dos puertas en la fachada sur. La principal, de forma perdida, está centrada y la secundaria se sitúa junto al ángulo oriental, adintelada al exterior y posiblemente arcuada al interior, que daría acceso a un coro delantero. El ábside tenía un arco de herradura, trasdosado y hoy recortado, y una ventana grande, de medio punto, tallada en dos sillares (como San Vicente del Valle 1). Su cúpula semiesférica se apoya sobre el vuelo de cuatro pechinas que a su vez apoyan sobre tímpanos ligeramente peraltados. El grosor de los muros
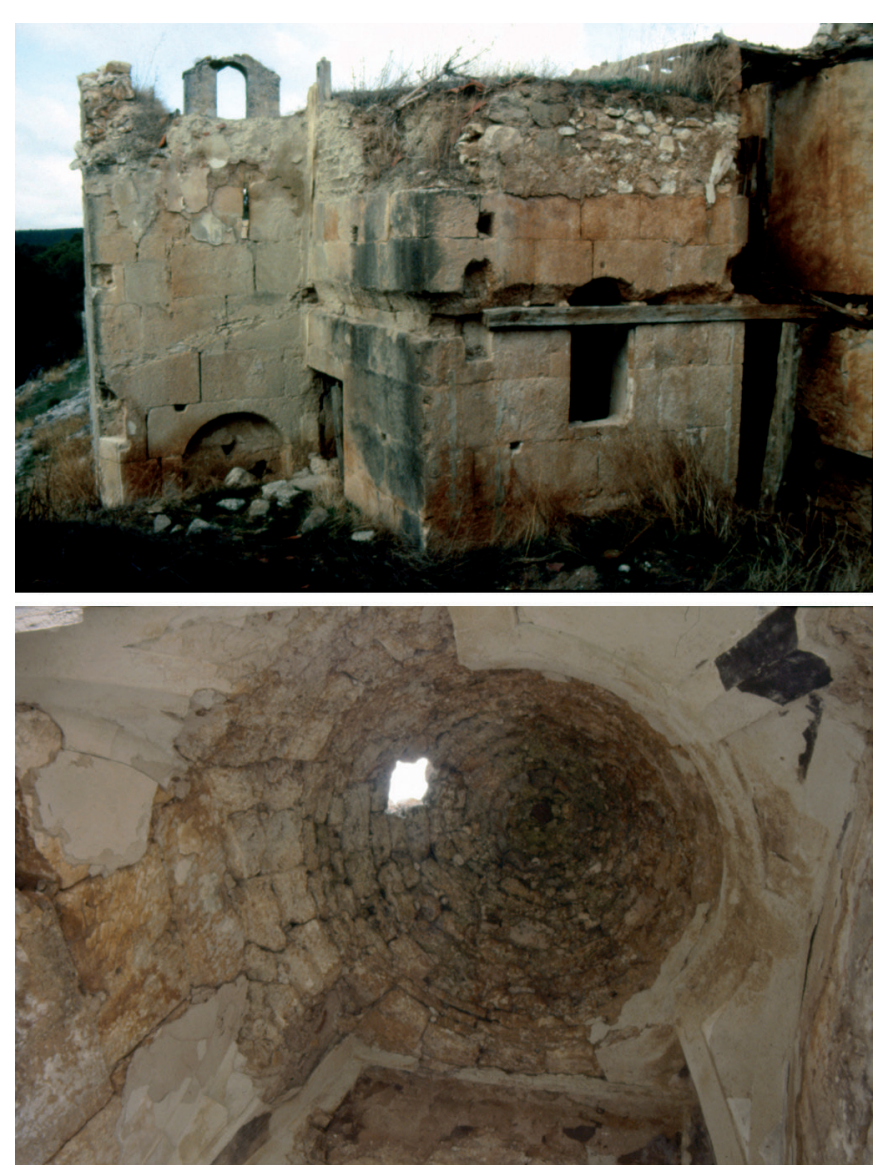

Figura 20.- San Pedro el Viejo de Arlanza (Hortigüela, prov. Burgos). Cabecera y bóveda del ábside.

del aula y el fuerte desplazamiento producido en los sillares del muro sur originario por la ruina hacen pensar que también debió estar abovedada, posiblemente con tres naves, dada la presencia de una pareja de ventanas asaeteadas abiertas en el testero oriental, quizás situadas a eje de las supuestas naves laterales (Caballero y Arce 2004. Según Utrero 2006, de existir las naves se separarían por arquerías sobre pilares. Recientemente la cúpula ha sufrido una restauración necesaria para su conservación pero de técnica inadecuada).

\section{Iglesias con dos etapas constructivas} prerrománicas. Tobillas y San Vicente del Valle

Estas dos iglesias ofrecen una secuencia constructiva de un mismo ambiente productivo.

La iglesia de San Román de Tobillas (prov. Álava) conserva restos de dos obras prerrománicas (aprox. 15,4 m x 5,4 m. Azkarate 1995, excavación; Utrero 2006; Sánchez Zufiaurre 2007: 206-219). La primera (Tobillas 1), situada 
sobre un yacimiento romano, utiliza tres tipos de material, dolomía reutilizada de grandes sillares para los cimientos y parte baja de los muros; caliza brechoide, que se asegura procede de cantera, de pequeño módulo, para la parte alta de los muros; y toba calcárea, de cantera superficial, para la bóveda del ábside, perdida. La sillería está cortada a regla lo que da un aspecto muy irregular al aparejo con hiladas desdobladas y de regularización, y abundantes cuñas y codos. Los muros son de dos hojas sin atizonar (ancho $0,9 \mathrm{~m}$ ). Se conservan los tres muros del ábside con los tímpanos de sus pechinas y una ventana asaeteada, rematada en dintel recortado en arco. El aula tendría una planta similar a la actual. En la segunda fase (Tobillas 2) se reconstruyó el aula desde los cimientos. El material procede de cantera local, tallada con regla pero con un aparejo de aspecto uniforme, con escasos y pequeños codos y cuñas e hiladas ligeramente onduladas. Sus ventanas son mayores, con dinteles arcuados (aparejo y ventanas como Quintanilla y San Vicente del Valle 1). Se desconoce a qué causa se debió la pérdida del aula originaria.

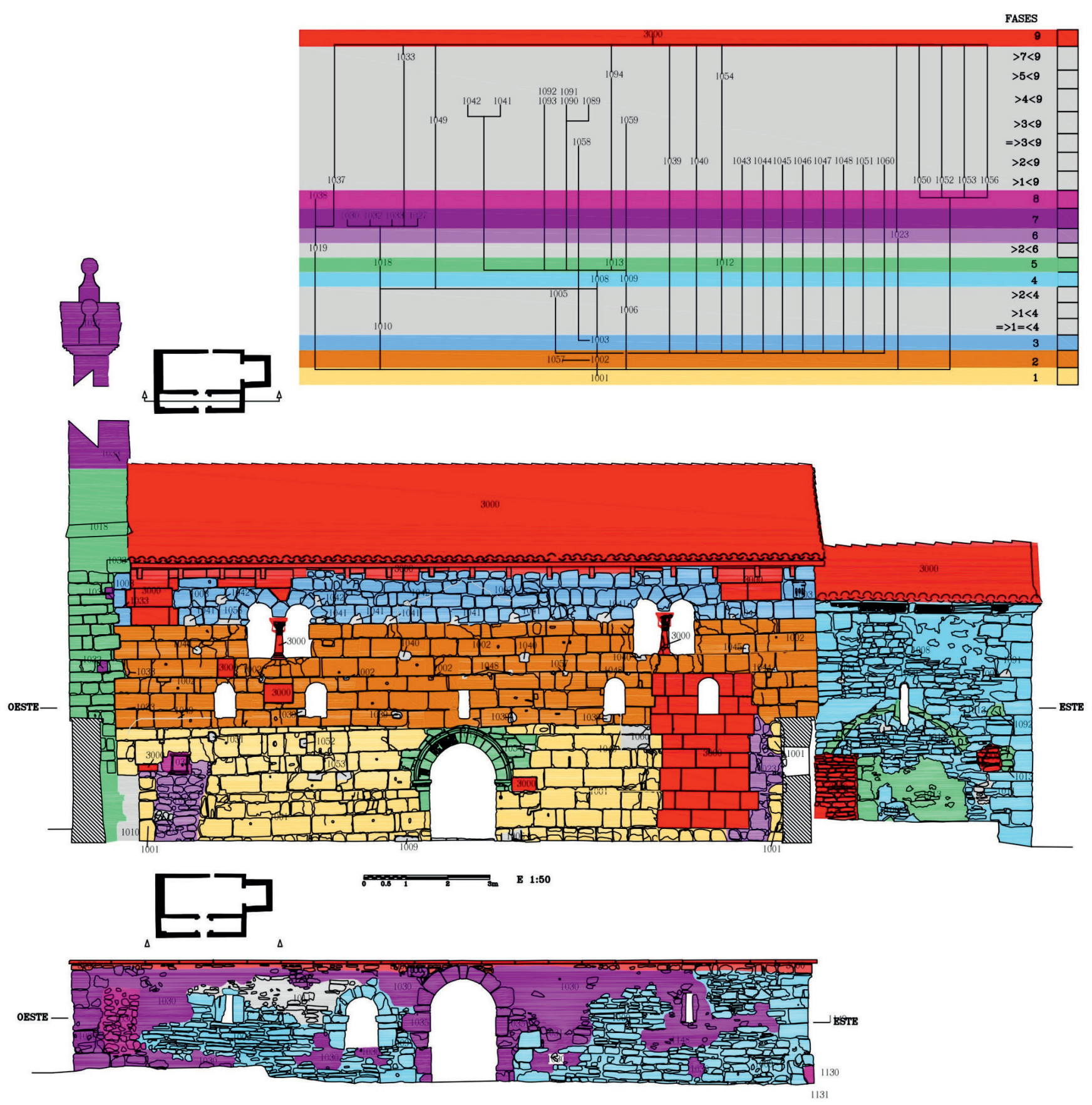

Figura 21.- San Vicente del Valle (Burgos). Estratigrafía del alzado sur (según Arce 2010). 
En la iglesia de San Vicente del Valle (o Santa María, La Asunción, prov. Burgos) se distinguen dos obras, una originaria y otra de restauración y ampliación. Cada edificio cubrió su ábside con cúpula sobre pechinas, lo que los sitúa en momentos consecutivos del mismo grupo productivo (Fig. 21. Huidobro 1932; Aparicio y Fuente 1993-1994, excavación y restauración tras su incendio; Utrero 2006: 168-169, aula no abovedada; Arce 2010).

La sillería de la primera iglesia es de arenisca y caliza procedente de expolio romano. La arenisca se utiliza en cimientos y primeras hiladas, mientras que, por encima, se invierte la proporción a favor de la caliza. En los sillares de arenisca se evitó recortar las caras de los sillares, abriéndose mechinales para andamios en sus esquinas inferiores; en los de caliza se alisaron sus caras y los mechinales se abren en el centro de las superiores. Todos los sillares se tallaron con regla consiguiendo un aparejo uniforme con escasos y pequeños codos e hiladas regulares, para lo cual hubo de organizarse previamente el material por tamaño.

Del primer edificio, construido y ampliado en dos fases, solo conocemos el aula, pero sabemos que tuvo un pórtico y un ábside. Los muros del aula $(17,8 \mathrm{~m} \mathrm{x}$ $8,7 \mathrm{~m} \mathrm{x} \mathrm{7,9} \mathrm{m)} \mathrm{son} \mathrm{estrechos}(0,6 \mathrm{~m})$ y de una hoja de sillería reutilizada, lo que obliga a que se cubriera con armadura de madera. El que las excavaciones no descubrieran indicios de posibles arquerías y las vertientes rectas de los testeros sugieren su organización en una nave única, a pesar de que la existencia de sendas troneras en el testero oriental pudieran argumentar la presencia de tres naves (como en Arlanza). Del pórtico solo se conocen sus arranques en los extremos de la fachada sur. El ábside, de planta cuadrada y exento (aproximadamente, $3,75 \mathrm{~m} \times 3,9 \mathrm{~m}$, ancho de muros $0,5 \mathrm{~m}$ ) se conoce por su zanja de construcción y la primera hilada de su cimiento. Abundantes restos de piedra toba rellenaban la zanja amortizada sugiriendo que se cubría con una bóveda de pechinas. La sustitución de este ábside por el segundo ha hecho que se pierda su relación con el aula, pero el material y el aparejo de ábside y aula es el mismo. A pesar de ello se ha dudado de su relación proponiéndose la existencia de un edificio anterior, civil y sin ábside (Aparicio y Fuente 1993-1994), propuesta forzada rechazada (Arce 2010: 93). El aula presentaba abundantes puertas y ventanas. La puerta principal se centraba en la fachada sur. Otra puerta se situaba descentrada en la fachada norte, con dintel dovelado perteneciente a la segunda fase. Cuatro puertas más se situaban respectivamente junto a las esquinas de la fachada sur (en relación con el pórtico) y del testero occidental. Se conocen restos de ocho ventanas, situadas a la misma altura y con marco rectangular abocinado al interior. Dos parejas se reparten a los lados de la fachada sur, rectangulares, con remate semicircular y talladas en la sillería del paramento. La ventana mayor se sitúa en el testero occidental, con arco dovelado. Una tronera se coloca sobre la puerta principal y otras dos, a los lados de la embocadura del ábside, cegadas al adosar el segundo ábside.

Con la segunda obra se sustituyeron el pórtico y el ábside, para agrandarlos. La altura del nuevo pórtico obligó a recrecer el aula y abrir nuevas ventanas por encima de su remate. Para ello se emplearon aparejos diferentes: sillería para el recrecido del aula y mampostería para el pórtico y el ábside. La semejanza técnica de las ventanas asegura que las labores fueron coetáneas. Las cuatro hiladas del recrecido del aula reutilizan los sillares de arenisca de la primera obra, recortados y con un aparejo más irregular. La mampostería del pórtico y el ábside es de lajas y sillarejos de esquisto, con abundante argamasa, cadenas de sillares en las esquinas y enfoscados los paramentos. El ábside se cubre con una cúpula de piedra toba, sobre pechinas de caliza que arrancan con arista, y se remata al exterior con una cornisa romana expoliada, quizás ya utilizada en el ábside precedente, completada con una cornisa de nacela. El pórtico se organizó interiormente en cinco tramos, un porche central y sendas parejas de habitaciones a cada lado. Antes de recrecer el aula se abrieron los huecos de dos parejas de ventanas en las dos hiladas superiores del primer edificio. Son ajimeces con columnilla central y arquillos de piedra caliza, dovelados de forma torpe. El ábside y las habitaciones extremas del pórtico tienen troneras abocinadas con marcos de sillería; y las habitaciones centrales del pórtico sendas ventanas (una perdida), grandes y con arcos dovelados, de técnica similar a las ventanas del recrecido del aula.

Mientras que los capiteles y basas de las columnillas de los ajimeces del aula son de mármol fino y pulido, los fustes se han realizado con caliza local y su superficie conserva el corte facetado para lograr la forma cilíndrica. Los capiteles proceden de un mismo taller, dada su similar estructura y técnica. Son de tipo corintio, sin collarino, con tres pisos de hojas y se caracterizan técnicamente por profundos surcos de trépano que recortan las hojas y dibujan los nervios. El arranque ondulado de los surcos en el asiento de los capiteles reserva una faja 
lisa que sustituye a los inexistentes collarinos. En los frentes de la pareja principal de capiteles, situada en la fachada sur, figuran caras. Los del muro norte tienen plaquetas aisladas en las esquinas del ábaco. El quinto capitel, mayor e incompleto, correspondía a la ventana del testero oriental. Un sexto capitel, rodado y reutilizado, apareció en las afueras de Villafranca Montes de Oca (Aparicio 2007). Y uno séptimo, fragmentado, al parecer realizado en "piedra del país", procede de la cercana iglesia de Santa María de Oca (Santa María de Fuentes, no San Felices de Oca, Osaba 1951). Las basas se molduran con dos toros o baquetones separados por media caña.

La homogeneidad de capiteles y basas obliga a desechar que procedan de expolio y a defender que se realizaron ex profeso para el edificio. Pero esto parece contradecirse con las características del ambiente productivo en que se les encuadra y con la cronología que se les otorga. Su material (supuesto mármol del Pirineo francés, con la discordancia del de Santa María de Oca), estructura y técnica se pone en relación con una amplia colección de capiteles de la Aquitania francesa que se data entre los siglos IV y VIII. Las piezas españolas se fechan por la mayoría de los autores en los siglos VI y VII, conforme con la cronología dada tradicionalmente al edificio, siglo VII, lo que explicaría la semejanza de las caras de sus capiteles con los de la iglesia de La Nave, datada también en esa fecha. Pero esto se opone a la cronología que hoy se otorga a estas iglesias y a los capiteles de La Nave (siglos VIII-IX) y a la semejanza que se puede observar con los capiteles de Córdoba, pertenecientes a talleres distintos, llamados de los evangelistas (considerado visigodo) y de los músicos (considerado califal). Si el ambiente productivo del norte de la Península en el siglo IX (fecha que a nuestro parecer tienen estas iglesias) desconoce la producción de capiteles de formato clásico, este grupo procedería del encargo o la adquisición a un taller lejano o forastero, ya fuera andalusí o derivado de los tardoantiguos aquitanos. El grupo homogéneo de capiteles españoles está compuesto por variantes pertenecientes a un mismo ambiente productivo altomedieval y no por derivaciones de grupos heterogéneos de distintos ambientes y cronologías (Aparicio y Fuente 1993-1994; Aparicio 2000 y Aparicio 2007; Arce 2010; Domingo 2011, aunque el capitel de los apóstoles procede de Córdoba, no de Almedinilla, según Santos 1958; Cruz 2009 relaciona los capiteles de La Nave, Quintanilla, Córdoba y Sant Germigny-des-Prés que data en el s. IX).

\section{Un tipo formal distinto. El edificio martirial de Santa Coloma}

El edificio de Santa Coloma (parroquia de La Asunción, Santa Coloma, prov. La Rioja) multiplica el ábside abovedado con cúpula sobre pechinas del grupo arquitectónico y acopla entre sí los elementos repetidos, para conseguir una forma adecuada a su función martirial o funeraria $(10,7 \mathrm{~m}$ x 5,4 m. Uranga e Íñiguez 1971; Heras 1986; López y Hernáez 1998, con una propuesta absurda de mausoleo romano y cabecera de basílica; Arbeiter y Noack 1999: 354-357; discutible restauración en 1999-2000; Utrero 2006: 168).

Se compone de tres cuerpos prismáticos, el central $(5,4 \mathrm{~m} \times 5,4 \mathrm{~m})$, mayor, de planta cuadrada y dos pisos, flanqueado por dos menores $(2,6 \mathrm{~m} \times 3 \mathrm{~m})$, a este y oeste, de un piso y planta rectangular exterior y cuadrada interior, colocados a una altura intermedia con respecto al central. Los espacios se cubren con cúpulas sobre pechinas; excepto la cripta del cuerpo central que posee una cúpula baída (única en el grupo; como Melque) de sección rebajada adecuada a su función de soporte del suelo del piso superior, cuya construcción será dovelada y no falsa para soportar la carga del suelo, aunque no se puede comprobar. La cripta reduce su espacio interior para ampliar el ancho de los muros (ancho $0,5 \mathrm{~m}$ en el piso superior, $1 \mathrm{~m}$ en la cripta) y la bóveda arranca desde el suelo para recoger mejor los empujes de la baída. Al contrario, el espacio principal, sobre la cripta, es mayor al cubrirse con una cúpula sobre pechinas que no provoca empujes, ampliando su planta y ganando tres veces en altura (1,9 m cripta, $5,9 \mathrm{~m}$ piso alto). Todas las bóvedas se construyen con toba calcárea. La del cuerpo occidental se distingue por decorarse con un friso de arquillos en el arranque (Fig. 22c, de toba, como Tricio). Dos puertas enfrentadas en el piso superior, con arcos sobre impostas que reutilizan cornisas romanas, abren a los espacios laterales, comunicados entre sí por tres tramos de escaleras. Por la puerta occidental se baja a su espacio lateral, desde él a la cripta, y desde ella se sube al espacio oriental donde se situaba el altar, adosado. Se asistía al culto desde el piso alto, a través de su puerta correspondiente, como un mirador sin escalera. La puerta de acceso al edificio estaba en el lado norte del piso superior, hoy tapiada y cortada por la puerta actual. Las ventanas originarias son la del testero del cuerpo oriental, rectangular y con dintel arcuado y la pareja de saeteras del piso alto. 

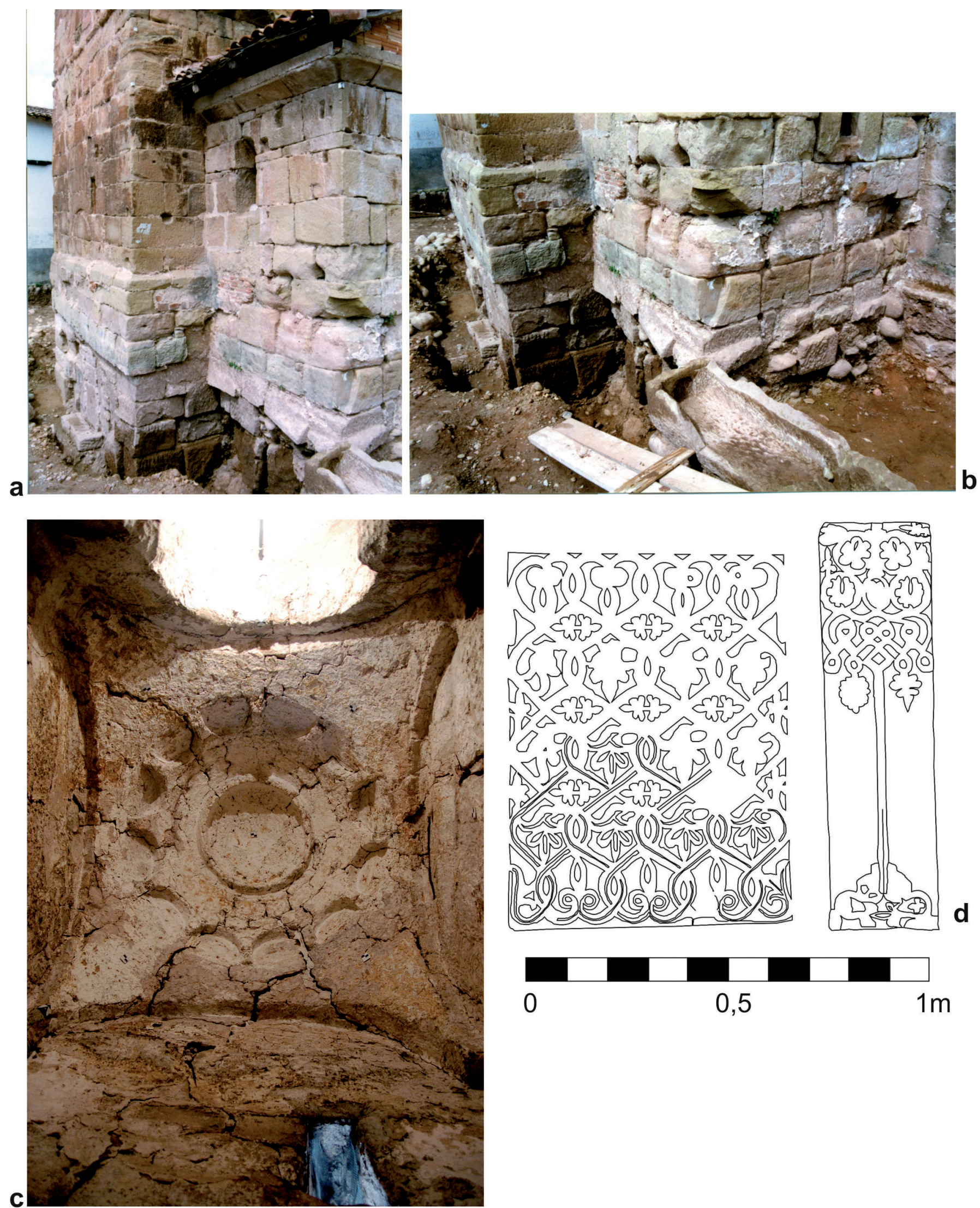

Figura 22.- Santa Coloma (prov. La Rioja). a y b, frente sudeste mostrando los cimientos durante las obras de restauración, en el cuerpo central se observa un zócalo de restauración moderna; c, bóveda baída del cuerpo oeste; d, dibujo de los estucos, escala 3/50 (d, dibujo Fernando Arce, G.I. Arqueología de la Arquitectura, IH, CSIC). 
Frente a lo que en ocasiones se ha pretendido, el edificio es unitario sin más fases que pobres añadidos y reparaciones. El material utilizado es sillería de arenisca de expolio romano, además de la toba calcárea procedente de cantera superficial. Los cimientos, que profundizan según la estructura de cada cuerpo, asientan sobre una capa de cantos rodados y se forman con sillares sin recortar ni alinear con los muros. Los sillares se tallan con regla, aparejando con regularidad, con escasos y pequeños codos, desdobles, sillares en forma de cuña, alguna hilada de regularización e hiladas ligeramente onduladas. Las caras exteriores de los sillares se alisan una vez colocados, dejando un escalón sin tallar al nivel del suelo. Los muros rematan con una cornisa sencilla a bisel (Fig. 22a y b, similar a la reutilizada en Aistra 2, Sánchez Zufiaurre 2007: 114).

Lució una decoración de estuco que, aunque se conserva parcialmente en el piso superior del cuerpo central, debió cubrir por completo el interior de todo el edificio, sin que nada contradiga que sea unitario con él (Fig. 22d). En la pared meridional queda un panel entre las dos ventanas $(0,95 \mathrm{~m} \mathrm{x} 0,75 \mathrm{~m})$ y otro entre la occidental y su rincón $(1,1 \mathrm{~m} \times$ x $0,3 \mathrm{~m})$. El central se decora con un entrelazo de tallos en red de rombos con trifolios y hojillas, con el dibujo boca abajo, lo que indica la falta de familiaridad de la cuadrilla de estucadores que quizás utilizaba patrones que no eran suyos. El lateral se decora con un "árbol de la vida" de base triangular y copa rectangular con entrelazos de palmetas, unidos por un largo tallo. En el muro norte resta un listel con uñadas. La estructura decorativa se formaría por un zócalo, una zona central con los paneles descritos y la decoración, desconocida, de tímpanos y bóvedas. Representa un jardín ideal (el Paraíso) cerrado por setos y con frutales.

$\mathrm{Su}$ estilo se relaciona con el arte islámico omeya y califal, aunque se le suponen un amplio abanico de paralelos desde la escultura visigoda toledana hasta la mozárabe de San Miguel de Escalada. Todos los autores la relacionan con la decoración de la mezquita islámica de la cercana Tudela (Navarra; primer cuarto del s. XI) con la que, aparte de cierto aire de familia de algunos motivos, es incierta la relación por la distinta estructura decorativa de los paneles.

\section{Ábsides aislados. Tricio y Montoria}

Del edificio originario de Santa María de los Arcos de Tricio (prov. La Rioja) solo se conserva su amplio ábside unitario $(5,2 \mathrm{~m}$ x 5,2 m x $8 \mathrm{~m}$. Taracena 1942 .
Excavaciones y restauración entre 1975 y 1987. Lo consideran equivocadamente mausoleo romano convertido en cabecera de iglesia tardorromana: Andrés Valero 1983; Cancela 1986; Heras 1986; Cancela 1992; Sáenz Preciado 1999. Ábside altomedieval para: Caballero, Arce y Utrero 2003; Utrero 2006: 168). Su sillería de arenisca es romana, reutilizada. Sus muros son de una hoja $(0,6 \mathrm{~m})$, con los sillares ordenados por tamaño y recortados a regla, de aparejo regular, con escasos codos, cuñas y desdobles e hiladas ligeramente inclinadas. Los cimientos son de mampostería con abundante cal. Las caras exteriores de los sillares se alisaron una vez colocados en obra, mientras que las interiores sin alisar se recubrieron con estuco, que probablemente estaría decorado (como Arlanza y Santa Coloma). La cubierta es de pechinas voladas que sostienen una cúpula que arranca con un friso de arquillos (como Santa Coloma). Se ha reformado el arco de acceso. Se desconoce la causa de la pérdida del aula originaria, algo más ancha que el ábside, de la que solo quedan los cimientos sobre los que asientan las columnas (tambores romanos reutilizados) de la iglesia actual.

En el suelo del ábside quedan restos de un mosaico, coetáneo, sobre el que descansaba el estuco de los muros (Fig. 23). Asentado sobre un lecho de cantos rodados, tenía un cuadro central perdido y en su lado oriental una franja decorada con círculos y rombos alternados en damero, que dejan entre sí rectángulos con dos lados curvos, rellenos con motivos geométricos, "nudos de Salomón" y "hederas". Los colores que utiliza son blanco para el fondo, azul oscuro, rojo y ocre.

Del ábside de San Miguel de Montoria (prov. Álava; aprox. 4,5 $\mathrm{m} \mathrm{x} \mathrm{4,5} \mathrm{m,} \mathrm{ancho} \mathrm{del} \mathrm{muro} \mathrm{0,6} \mathrm{m)} \mathrm{restan}$ los arranques de sus lados e indicios de sus enjarjes al testero del aula, sin bóveda documentada cuya existencia se supone por sus paralelos. El aparejo es de sillares

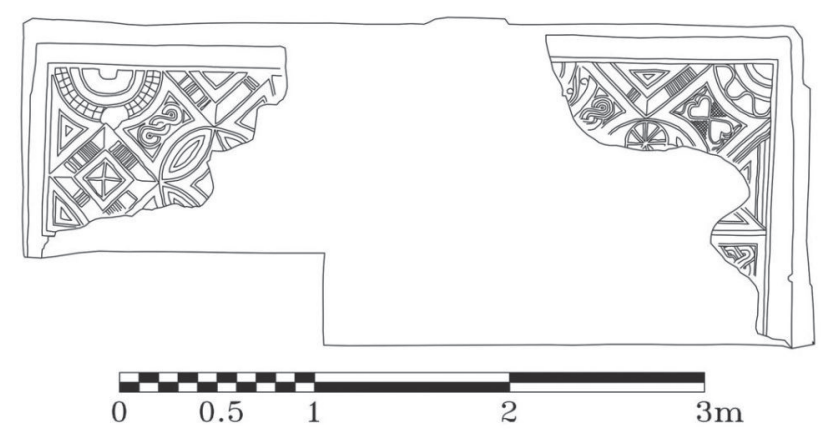

Figura 23.- Santa María de los Arcos de Tricio (prov. La Rioja). Dibujo del mosaico del suelo del ábside. Escala 1/50 (dibujo Fernando Arce, G.I. Arqueología de la Arquitectura, IH, CSIC). 
reutilizados ajustados a regla. Se trata de la iglesia de un asentamiento nobiliario de los Ramírez de Montoria, anterior al siglo X (Sánchez Zufiaurre 2007: 180-184).

\section{Edificios de mampostería y sillarejo}

Además de la segunda etapa de San Vicente del Valle, ya estudiado, incluimos los siguientes edificios.

La iglesia de Santa Cecilia de Tabladillo (Barriosuso, Burgos) es de aula con ábside exento de planta cuadrada y un pórtico (12,5 m x 5,8 m sin pórtico; testero occidental perdido; ábside $2,8 \mathrm{~m}$ x 3,5 m. Restauración 1889 y 1976; excavación arqueológica del entorno, inédita, 1988. Toribios y Sáiz 1925; Osaba 1976; Carretón 1992; Utrero 2006: 169). Los muros son de dos hojas $(0,6 / 0,7 \mathrm{~m})$, construidos con sillarejo y mampuesto de piedra caliza, de colocación, tamaño y forma irregulares, con cadenas en esquinas y jambas de puertas. Aunque sin indicios de reutilización, los sillarejos deben proceder del yacimiento romano sobre el que se asienta la iglesia. La nave del aula se cubre con armadura de madera, restaurada. En la esquina suroriental del aula se conserva el arranque del pórtico originario. El esquema de puertas recuerda el de San Vicente del Valle y Arlanza 1: una puerta central, hoy sustituida, y dos junto a cada esquina del muro sur, tapiadas, con cargaderos de madera y marcos de grandes sillarejos ( $i$ acceso a coro y baptisterio?). El arco del ábside debió ser de herradura, hoy recortado. El ábside se cubre con una cúpula sobre pechinas de piedra toba (Fig. 24). El muro sur del aula tiene dos saeteras, con dintel arcuado, y el testero del ábside una ventana cuadrada, con celosía de piedra, que se considera original.

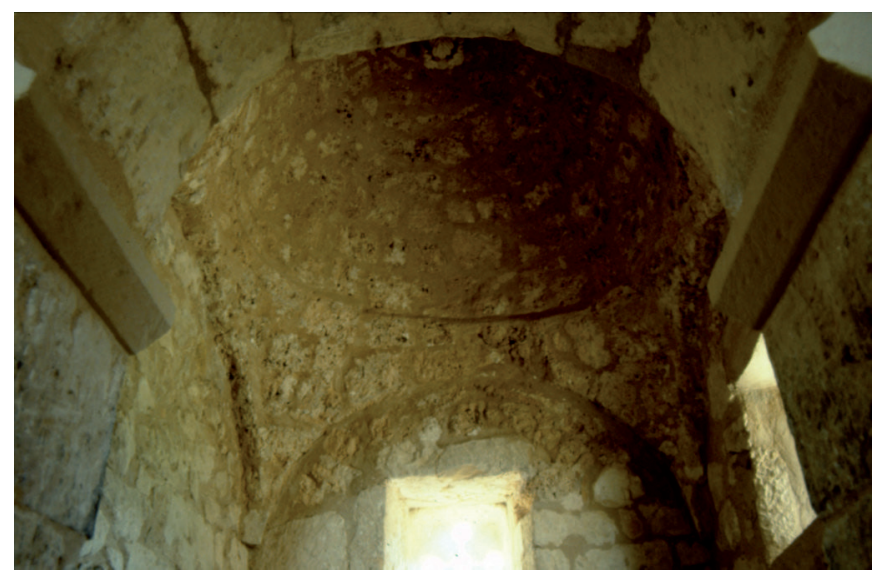

Figura 24.- Santa Cecilia de Tabladillo (Barriosuso, prov. Burgos). Bóveda baída del ábside.
El ábside de San Esteban de La Canejada (Cervera del Rio Alhama, prov. La Rioja. 3,9 m x 4,6 m, grueso de muro $0,8 \mathrm{~m}$. Utrero 2007) se construye con sillarejos y lajas de caliza y mampuestos de arenisca, sin indicios de reutilización, de aparejo irregular reforzado en las esquinas. Se observan arranques del aula que sería de una nave más ancha que el ábside. Su cubierta es de nuevo una cúpula de toba alzada sobre pechinas resaltadas. El ábside de Nuestra Señora de Las Eras (Hérmedes de Cerrato, Palencia. 6,25 m x 6 m. Escudero 1942-43; Arbeiter y Noak 1999: 323, Utrero 2006: 169) es de mampostería de caliza reforzada con sillares o sillarejos. El arco del ábside es de herradura cerrada con impostas mozárabes y su cubierta, la típica de cúpula sobre pechinas, enfoscada, que se supone de toba. El aula está perdida.

\section{IGLESIAS CASTELLANAS CON BÓVEDAS DE TOBA PERTENECIENTES A OTROS GRUPOS CONSTRUCTIVOS. SIERO Y ELINES. RETORTILLO, PEDRO Y GORMAZ}

Otros edificios, construidos de mampostería, poseen también bóvedas de cañón de piedra toba (ábsides). Motivos decorativos de dos de ellos (Santas Céntola y Elena de Siero y San Martín de Elines) se relacionan con los del taller de Quintanilla. Salvo Gormaz, el conocimiento de estas iglesias es escaso, por lo que sus interpretaciones son revisables. Iglesias de otros grupos regionales también tienen bóvedas de piedra toba: en Asturias: Bendones, quizás Gobiendes, Lillo, Naranco y Valdediós; en Cantabria: Lebeña; en La Rioja: Suso y Torrecilla de Cameros; y en Castilla y León: Berlanga y quizás Mijangos. Estas iglesias obedecen a grupos técnicos y cronológicos específicos, de modo que, por ejemplo, en Asturias se distingue un grupo con bóvedas de piedra toba y otro con bóvedas de ladrillo.

La pequeña ermita de Santas Céntola y Elena de Siero (Valdelateja, Burgos) es de una nave y un ábside exento de planta cuadrada ( $9 \mathrm{~m} \times 5 \mathrm{~m}$. Fig. 25). La nave está rehecha, mientras que el ábside en parte es originario. Se construye con sillares (probablemente expoliados) y sillarejo de caliza. El arco del ábside es de ligera herradura sobre impostas con nacela, flanqueado por dos nichos o altares/nicho. La bóveda es de cañón de herradura, realizada con dovelas grandes de piedra toba, que arranca directamente de los muros, sin impostas. 
Su ventana oriental se cubre con un dintel, recolocado y recortado, arcuado en herradura, a cuyo espacio libre se ajusta una inscripción y su decoración. Por encima de ella corre una cornisa con nacela, de restauración, que cortó su parte superior. La fecha se ha cortado para borrarla:

(Cruz patada con alfa y omega) Fredenandus / et Gutina (cruz potenzada con omega) / Era DCCCXV [DCCCXIV] (777 o 776 d.C.) (motivo vegetal)

Además se encontró una "lipsanoteca" con la inscripción cursiva (Sastre 2013: 330):

(Cruz con alfa y omega y astil) Siprianus fecit (rúbrica)

¿Es posible que el dintel de Fredenandus y Gutina pertenezca a la fecha que documenta? Estos personajes se han puesto en relación con unos supuestos condes de Castrosiero, datados por un documento apócrifo en época de Alfonso III y el conde Rodrigo (entre 852/c.860 y 873/910), en contradicción con la fecha de 777 . Por otra parte, letra, renglones y el "árbol de la vida", en relieve, recuerdan la manera de hacer y los motivos de Quintanilla, por lo que sus datas deben asimilarse al mismo momento cronológico, lo cual de nuevo es contradictorio para su fecha, tanto si Quintanilla se data como visigoda del s. VII o como condal de hacia el año 900. Para explicarlo se ha supuesto que la inscripción estaría corregida, lo cual no es cierto como demuestra la pieza, o que se debiera a un error de traza la falta de una cuarta cifra $C$ (Huidobro 1928-1929; Íñiguez 1934, 1955; Pérez de Urbel 1945; Camón Aznar 1963; Noak 1987; Barroca 1990; Caballero 1994-1995; Martín Viso 1995; Arbeiter y Noak 1999; Fernández Flórez 2002; Utrero 2006: 120, 515).

La colegiata románica de San Martín de Elines (Valderredible, Santander) conserva restos de dos edificios prerrománicos, de los que aquí interesa el acostado al norte de su claustro, aunque la falta de un adecuado estudio dificulta su adscripción. Los restos conservados y los conocidos por excavación definen un aula de tres naves separadas por arquerías con cinco arcos de herradura y un pequeño ábside exento cubierto con bóveda de piedra toba de la que desconocemos su tipo $(10,75$ $\mathrm{m} \times \quad$ ¿ $7 ? \mathrm{~m})$. La construcción es de sillería de arenisca. El edificio sufrió una o varias ruinas que se restauraron amortizando las naves laterales y adosando nuevos muros al exterior de las arquerías, y sustituyendo el ábside originario por el actual mayor. En los muros adosados
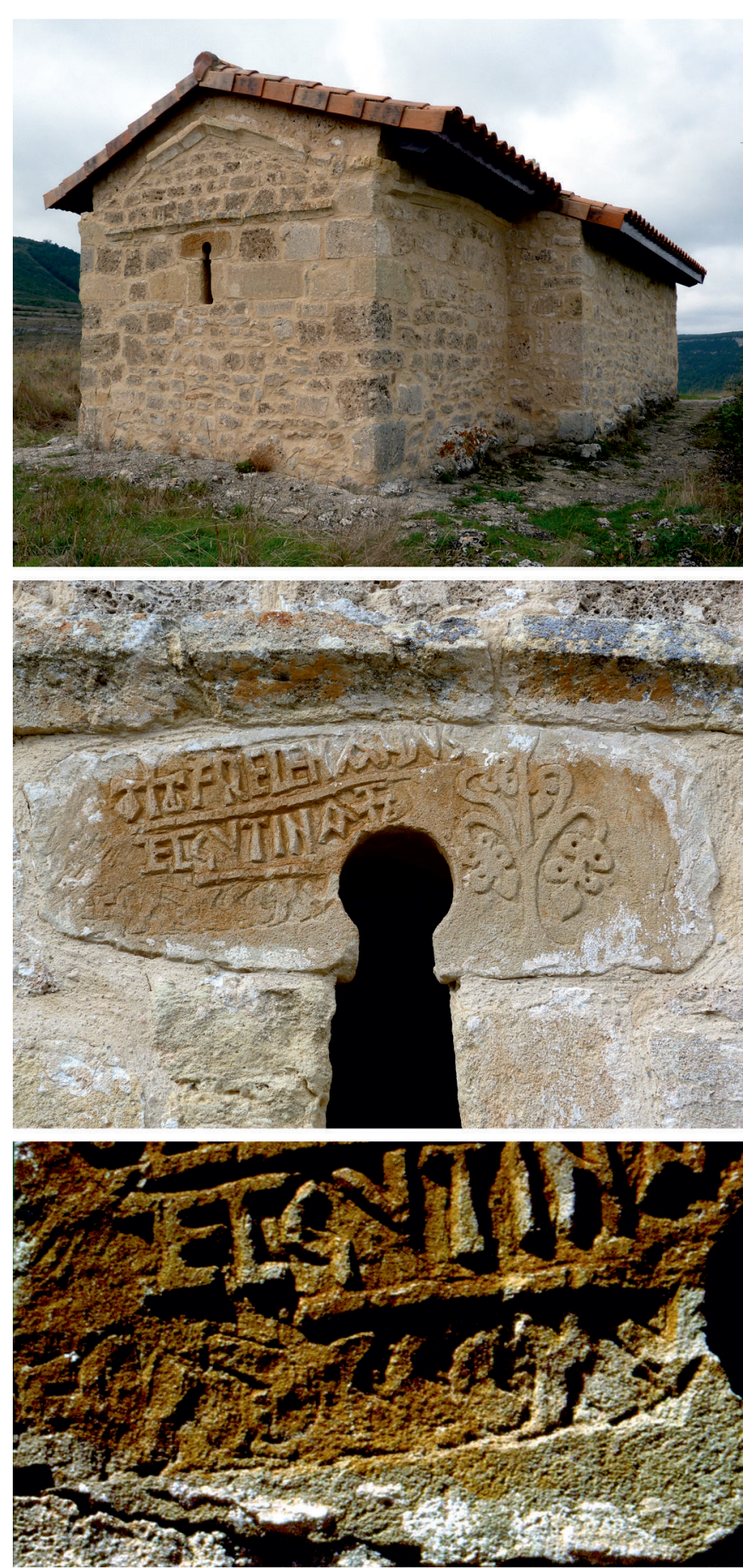

Figura 25.- Santas Céntola y Elena de Siero (Valdelateja, prov. Burgos). Vista general y detalle del dintel arcuado de la ventana del ábside (los dos negativos superiores de Alejandro Villa del Castillo).

se reutilizaron dos ventanas con dinteles arcuados en herradura y decorados con alfiz moldurado, "árboles de la vida" y temas vegetales que se relacionan con el repertorio de Quintanilla y Siero, y se deben fechar avanzado el s. X. Desconocemos la cubierta del aula que pudo ser abovedada si atendemos a la ruina (Arbeiter y Noak 
1999: 329; excavación, Domínguez Bolaños 2003; García Guinea 2007: 1426, 1433, 1474, arruinada en 1102).

La iglesia de Santa María del Retortillo (Torrepadre, Burgos) suma a la ausencia de un estudio riguroso una lamentable reconstrucción. Se compone de una nave construida de mampostería reforzada con sillares de caliza, y un ábside abovedado, cuyos arranques son de dovelas alargadas de piedra toba. El actual arco de ábside, de herradura con alfiz, y la existencia de modillones de rollo se utilizan para datarla en el s. X avanzado, a lo que se unen sendos conjuntos de relieves descontextualizados de factura altomedieval y de época románica (Arbeiter y Noack 1999: 329; Palomero 2002: citas en los años 954 y 1048).

La pequeña ermita de La Virgen del Val o de La Val, Pedro (Soria), es también de nave con ábside cuadrado exento y un porche meridional de madera (16,9 $\mathrm{m} \mathrm{x} \mathrm{7,4}$ $\mathrm{m})$. La nave sustituye a la originaria perdida. El ábside también posee dos etapas que solo se pueden observar al exterior de modo que no se puede afirmar a cuál de ellas pertenece su bóveda, de cañón sin imposta y con dovelas de toba. Se ha datado en época visigoda por la decoración de las impostas de sus puertas que están reutilizadas. La etapa originaria se fecha por un "alquerque" entre el s. VIII, cuando este juego se introdujo por los árabes, y el s. XI de la segunda etapa románica (Ortego 1958 y 1983; Casa e Izquierdo 1992, decoración "visigoda"; Huerta 2002; Utrero 2006: 516; excavaciones entre 2006-09, "Pedro" [en línea]).

La iglesia de San Miguel de Gormaz (Soria) se sitúa en la falda del cerro del castillo homónimo (reconstruido por al-Hakam, 961-976). Consta de una nave con dos puertas, meridionales, una centrada restaurada y otra trasera originaria con arco de herradura con nacelas; un ábside exento de planta rectangular; y un pórtico meridional (22,6 $\mathrm{m} \times 8,3 \mathrm{~m})$. Tanto la nave, originaria y unitaria, como el ábside se construyen con mampostería de cal encofrada y reforzada. Pero el ábside sufrió una restauración inmediata a su construcción, de modo que su bóveda, de cañón con dovelas de piedra toba, sustituiría a otra similar. Las excavaciones han demostrado que el edificio se construyó sobre niveles y silos de los siglos IX-X. El ábside se decora al exterior con una cornisa que se ha supuesto de "estilo visigodo" y posteriormente fabricada ex profeso para el edificio, pero que, al margen de su cronología, se debe considerar reutilizada (datada en la segunda mitad del s. XI, como la iglesia, posterior al abandono islámico del castillo hacia 1060 y por análisis de C14 del cargadero de madera de la puerta trasera. Ortego 1983; excavaciones entre 1996-2000, Heras, Escribano y Balado 2001; y Balado, Escribano y Heras 2008; Utrero 2006: 500).

Fuera de grupo, se debe citar también la iglesita de Las Tapias (Albelda de Iregua, prov. La Rioja) que, a pesar de lo que se pretende por su supuesta planta cruciforme, nada tiene que ver ni con San Vicente del Valle ni con la arquitectura "visigoda" (14,4 m x 10,2 m. Excavaciones: Taracena 1927; y Espinosa 1983 y 2011, quien erróneamente duplica el edificio; Utrero 2006: 622). Los muros eran de mampostería de cantos de río como posiblemente la bóveda de la cripta; el resto se cubría con armadura. Su planta está formada por una sala rectangular, con un muro delantero, atravesado a modo de cancel, que segregaba un espacio de coro, y cuatro habitaciones a cada lado, ábside, cripta trasera (sobre la que se inventa un "contracoro" o tribuna), un porche al norte y al sur un almacén con entramado para una segunda planta. Se pretende datar en el s. VII, pero sus caracteres constructivos le otorgan una cronología altomedieval.

\section{LA PRODUCCIÓN CONSTRUCTIVA Y DECORATIVA DEL GRUPO DE EDIFICIOS CON "CÚPULAS SOBRE PECHINAS" DE PIEDRA TOBA}

Estos edificios se producían por talleres o cuadrillas especializadas que trabajaban en coordinación. Canteros que utilizan sillería reutilizada que cortan a regla, sustituidos por albañiles en los edificios de S. Vicente del Valle 2, Tabladillo, La Canejada y Hérmedes; en todos, canteros expertos en extraer piedra toba y abovedar con ella, cuya labor caracteriza al grupo; carpinteros para andamios, cimbras, cargaderos, armaduras y quizás para refuerzo de los aparejos; y estucadores que decoran algunos edificios. Fuera de esta labor uniforme y coordinada, el grupo carece de maestría escultórica, recurriendo a piezas de expolio: fustes (Quintanilla, Oca, Ventas Blancas) y cornisas utilizadas como tales o como capiteles (San Vicente del Valle 2, Santa Coloma, Oca). Aparece escultura decorativa en la iglesia de Quintanilla, producida por un taller ambulante con escasa repercusión en otras obras locales; capiteles, quizás de comercio, en San Vicente del Valle; y mosaicos en Tricio.

La arquitectura de este grupo se ajusta a una planta modelo: aula rectangular con ábside (santuario) cuadrado aislado y, en ocasiones, habitaciones (sacristías), 
también cuadradas y aisladas y colocadas en los extremos orientales de los lados largos del aula. Los ábsides se cubrían con las bóvedas sobre pechinas de piedra toba y las aulas, con armaduras. No podemos asegurar si en ocasiones se abovedaba también el aula, de una o tres naves. Los edificios de Arlanza, Oca y Ventas Blancas ofrecen indicios en este sentido que no es posible concretar por su estado, restaurado o en ruina, o por la falta de su estudio adecuado. Normalmente sólo se conserva el ábside gracias a la estructura estabilizadora de su abovedamiento que, sin empujes laterales, ata los muros, mientras que se arruina y se pierde el aula. Este proceso, señal de la escasa estabilidad del sistema estructural y constructivo del grupo, se inició en la alta Edad Media obligando a restauraciones históricas (Quintanilla, Arlanza, Tobillas, San Vicente del Valle, Tricio, Canejada, Montoria, Hérmedes).

La forma de los edificios se relaciona con la actuación litúrgica. Los de planta sencilla plantean el problema de la inexistencia de sacristías, función que suponemos cumplen las habitaciones exentas laterales. San Vicente del Valle y Tabladillo presentan tres puertas en la fachada meridional, una principal en el centro y otras en sus extremos, indicando una jerarquización litúrgica interna. La puerta más oriental daría juego a un espacio de coro delante del santuario (también en Arlanza). La misma división litúrgica podría suponerse en los edificios con sacristías laterales (Oca y Ventas Blancas). Pero se desconocen restos escultóricos pertenecientes a canceles, cierres litúrgicos de coros, como los de época tardoantigua y los de otras iglesias altomedievales, o sus huellas en la arquitectura. El espacio de la iglesia de Quintanilla se organiza en dos zonas. El muro occidental del transepto sirve de cierre litúrgico entre el coro (que se supone de carácter monástico, Moreno 2011) y el aula, cada uno con su acceso individualizado. El transepto actúa a la vez como espacio de comunicación entre el santuario, las sacristías y la sala del aula. Estructura y función similares a las de El Trampal, Melque y La Nave. Al margen de la tribuna occidental (como las de las iglesias asturianas), desconocemos la función de las habitaciones laterales del aula, que son imprescindibles estructuralmente, igual que en El Trampal.

Son singulares los edificios abovedados y decorados de Quintanilla de Las Viñas y Santa Coloma, debido a las condiciones funcionales y técnicas requeridas por sus promotores. Quintanilla aparenta el esquema tipo con ábside y habitaciones laterales sobresalientes, pero complica su forma interior para sostener una estructura abovedada, con transepto, nave con habitaciones laterales y tribuna sobre el porche de entrada. Su transepto abovedado y con crucero repite los del grupo de las primeras iglesias altomedievales (El Trampal y Melque) y será recurrente en otros grupos productivos (La Nave y Santa Comba de Bande). En la alta Edad Media hispánica, distintos grupos productivos, ante encargos extraordinarios, aplican sus técnicas constructivas propias a la obtención de estructuras con transepto de traza conocida. Esto invita a aceptar que las trazas dependen de "escuelas" de proyectistas, independientes de los "talleres" constructivos. Lo mismo parecen indicar las trazas modulares (Baños, Caballero y Feijoo 1998; Arlanza, Caballero y Arce 2004; Caballero y Utrero 2005; Arias 2012). Por otra parte, la decoración de Quintanilla destaca no sólo por su calidad, sino por su colocación en el exterior del edificio, recorriendo los paramentos de la cabecera y del transepto y quizás los del aula, lo que la convierte en única dentro de la producción altomedieval hispánica (Baños ofrece decoración al exterior pero sin un programa decorativo como Quintanilla). Todo ello indica su dependencia de un importante promotor, probablemente vinculado a los condes de Castilla, decidido a realizar una iglesia monástica extraordinaria, para lo que conforma un equipo constructivo y decorativo adecuado, de modo que su obra escapa a la unidad del grupo.

Santa Coloma, un martyrium o edificio funerario, multiplica el elemento del ábside abovedado, adosando tres cuerpos de planta cuadrada, el central mayor que los situados a oriente y occidente, destacado y superpuesto a una cripta. Su decoración estucada debía cubrir por completo su interior.

Las embocaduras de los ábsides que no se han recortado posteriormente y los escasos arcos supervivientes (Quintanilla, Oca y, de aceptarse, Elines) presentan arcos de herradura. Sin embargo, otros huecos de acceso a las iglesias y la mayoría de las ventanas se dintelan (San Vicente del Valle, Quintanilla, Oca; Siero y Elines). En Tabladillo (mampostería) las puertas utilizan cargaderos de madera. Las ventanas tallan sus dinteles arcuados al exterior y los dejan rectos al interior (Quintanilla, San Vicente del Valle). En San Vicente del Valle 2 se resolvió mal el excepcional dovelaje de huecos dobles arcuados.

Los talleres de cantería que trabajan para estos edificios utilizan sillería que procede de desmontes sistemáticos de edificios romanos, al parecer inmediatos a la obra, como indican las huellas de manipulación, 
epígrafes o decoraciones (Quintanilla, Arlanza, Tricio, Santa Coloma, etc.). Queda la duda de si en estos edificios se pudo mezclar la sillería de expolio con la procedente de cantera (caliza brechoide de Tobillas), indiferenciada si fue tratada del mismo modo. Técnicamente no debió haber diferencias notables entre la obra de cantera y la de expolio, de modo que la existencia o no de canteras no dependía tanto de las condiciones técnicas como de la ausencia de unas necesarias condiciones sociales. En este grupo productivo se utiliza específicamente la sillería de expolio, trazada a regla y ajustada a pie de obra, sin utilizar nivel, y careada una vez puesta en obra, como demuestran las huellas que afectan a las juntas (Quintanilla). Es otro rasgo de su homogeneidad como taller. Esta labor es indudable en los edificios donde se recortaron y alisaron las caras exteriores de los muros, mientras que los sillares de las interiores se dejaron tal como se habían obtenido o con un tratamiento básico, para luego estucarlas (Arlanza, Tricio). En Santa Coloma se diferencian los sillares tallados de los muros aéreos, de los sin tallar que se colocan en los cimientos ocultos.

En los muros se tantean alternativas constructivas y estructurales, como su formación con una o dos hojas. En las aulas de Quintanilla y Arlanza se utiliza como mecanismo de refuerzo el engatillado longitudinal y transversal de los sillares, ante la renuncia a engrosar lo suficiente los muros y a utilizar contrafuertes y tizones o sillares travesaños. Llama la atención esta renuncia al uso del atizonado que ya está presente en iglesias del s. VIII (EL Trampal, Melque). También son de dos hojas los muros del ábside de Tobillas; Oca, con hormigón de relleno; Ventas Blancas, con sillares travesaños; y Tabladillo, de mampostería. Sin embargo algunos ábsides utilizan muros de una hoja a pesar de abovedarse con pechinas (Arlanza, Tricio). Da la impresión de que los talleres constructivos experimentan.

Los constructores también utilizaron distintos tipos de material para funciones distintas. La arenisca o la dolomía se utiliza en grandes sillares de forma rectangular para los sillares de cimiento y de las hiladas bajas, mientras que se prefiere la caliza, con sillares de tamaño menor y frente cuadrado, para el alzado de los muros, o la caliza blanca menos porosa para las roscas de los arcos (Quintanilla, Oca, Arlanza, S. Vicente del Valle, Tobillas) o para las hiladas decoradas (Quintanilla). No se utilizan mechinales para sujetar andamios salvo las excepciones de Arlanza y San Vicente del Valle, con sus variantes. Solo conocemos los cimientos de Tobillas,
Tricio y Santa Coloma, los dos últimos ambos en zanja, con una cama de cantos rodados y sobre ellos sillares sin recortar. El robo de las profundas zanjas de cimentación de Quintanilla se debería a cimientos de sillería que interesaba reutilizar.

La segunda cuadrilla especializada que trabaja en estos talleres es la de canteros de piedra toba que realizan bóvedas sobre pechinas. La toba caliza abunda en el territorio del grupo (estribaciones del Sistema Ibérico, sierras de La Demanda y Atapuerca, y Montes Vascos); es fácil de obtener y de tallar; de poco peso, lo que reduce sensiblemente los empujes laterales; y de rápida adherencia, lo que ayuda a que su empleo sea habitual en este y otros grupos productivos (Utrero 2006: 160). Estas cuadrillas se diferencian de las de sillería en que consiguen sus materiales en canteras de superficie, recurriendo a procesos de acopio y transporte. Además suelen influir en la producción aportando su material y colaborando en la construcción del ábside más allá de la expresa de las bóvedas. En Arlanza la toba se talla en forma de laja y ladrillo o adoquín para utilizarlas en falsa bóveda (Fig. 20), pero en otros edificios del grupo adquieren forma de sillares (Ventas Blancas y Tabladi1lo, Fig. 19 y 24). En otras iglesias castellanas (Siero, Retortillo, Pedro, Gormaz) se utilizan grandes dovelas. Estas diferencias indican diferentes grupos productivos. Sobre los tímpanos recortados o los arcos de los vanos, utilizados como formaletas perdidas, se construyen las pechinas sobresalientes, que arrancan como nervios y cierran formando un anillo volado. La construcción de falsa bóveda sólo requería dovelar las piezas en el cierre. Todas las bóvedas de toba que conocemos son sobre pechinas, salvo la baída de la cripta de Santa Coloma por su función estructural y constructiva de suelo. Suponemos que serían bóvedas de cañón las de las naves y habitaciones de Quintanilla (con sus excepciones conocidas), Arlanza y Oca.

El tamaño de los ábsides de estos edificios permite suponer una secuencia en sus producciones. Los de Tobi1las, Montoria, Tricio, Oca y Quintanilla tienen el mismo tamaño (ancho exterior entre 5,2/5,3 m). Las iglesias de Ventas Blancas, Arlanza, San Vicente del Valle 1 y Elines poseen ábsides menores (entre 3 y $4 \mathrm{~m}$ ). Estos edificios, con ábsides de tamaño homogéneo y aparejo de sillería, forman el núcleo principal del grupo productivo. A él se puede añadir Santa Coloma, también de sillería, que ofrece tres dimensiones distintas para sus "ábsides" (de Este a Oeste, 2,5 m, 5,4 m y 2,9 m). El ábside actual de San Vicente del Valle 2 (de restauración) y el de Hérmedes 
(fuera del territorio) son los mayores $(6,45 \mathrm{~m}$ y $5,9 \mathrm{~m})$. Además, estos dos ábsides se construyen con mampostería, abandonando el aparejo de sillería reutilizada. Es posible que correspondan a una fecha más avanzada. Si estos argumentos son aceptables habría que añadir a esta última producción las iglesias de mampostería de Tabladillo (a pesar de que su ábside es el más pequeño, $2 \mathrm{~m}$ ) y de La Canejada (4,6 m).

Llegados a este punto debemos comparar lo dicho con los resultados obtenidos en el estudio de los talleres constructivos altomedievales de la provincia de Álava (Sánchez Zufiaurre 2007: 267 ss.). Según este estudio Tobillas 1 y Montoria forman parte del grupo 1, siglo IX, caracterizado, entre otras variables, por la utilización de sillería reutilizada. Posteriormente se aplicó la misma metodología (clusters de variables) a otras iglesias entre las que se encuentran algunas que pertenecen al conjunto que estudiamos aquí, ordenándolas en tres grupos (Sánchez Zufiaurre 2009):

- Grupo I (asimilable al grupo 3 alavés, s. X, Tobillas 1 y Montoria), Ventas Blancas y Quintanilla. Técnica de cantería con sillería ex novo.

- Grupo II (asimilable al grupo 1 alavés, s. IX), Arlanza, Santa Coloma, San Vicente del Valle, Tricio y Oca. Técnica de cantería con sillería reutilizada.

- Grupo III (asimilable a los grupos 4, 5 y 6 alaveses, con una cronología abierta entre los siglos IX y XI), Tabladillo y Hérmedes de Cerrato. Técnica de mampostería.

Su estudioso señala el carácter especulativo de estas adscripciones en tanto que relacionadas con la asignación genérica a los modos constructivos altomedievales demostrados en Álava y como ejemplo de aplicación al método allí utilizado. Estamos de acuerdo con estas advertencias (Sánchez Zufiaurre 2009: 235 y 239; análisis más detallados, número de variables tenidas en cuenta, estudios locales o regionales). Lo que decimos aquí matiza las conclusiones obtenidas, ratifica la validez de la metodología y anima a su aplicación rigurosa.

Asimilar las iglesias de Quintanilla y Ventas Blancas al grupo 3 alavés no es adecuado ya que ambos edificios reutilizan sillería, debiendo trasladarse al grupo II, equivalente al grupo 1 alavés; grupo en el que se deben inscribir las demás iglesias con técnica de cantería. Es cierto que en ocasiones no es segura la reutilización de sillería dado que en el proceso productivo se pudieron borrar las huellas del uso previo, pero esto, que puede considerarse en el caso de Ventas Blancas, no ocurre en el caso de Quintanilla donde las huellas de reutilización son evidentes (Fig. 2). Sin embargo, la apariencia del aparejo de sillería de Quintanilla se asemeja más a la del grupo 3 alavés (Tobillas 2, Sánchez Zufiaurre 2007: fig. 137; Ullíbarri, Sánchez Zufiaurre 2009: fig.1) que a la del 1 alavés (Tobillas 1, Sánchez Zufiaurre 2007: fig. 134), debido a la utilización de la regla para la talla de sillares y a la ausencia de hiladas de regularización de mampostería. En resumen, las variables del conjunto estudiado pueden aparentar un grupo homogéneo. Sin embargo, dado nuestro actual nivel de análisis, debemos afirmar que esta sensación la provoca su pertenencia al mismo ambiente técnico y, dentro de él, a un conjunto definido por las bóvedas con pechinas y de piedra toba. La presencia de técnicas de cantería y albañilería evidencia que los edificios correspondientes deben pertenecer a distintos talleres constructivos que faltan aún por definir.

Los estucos decorados de Santa Coloma (un jardín ideal con cercas y árboles que probablemente cubriría el interior de todo el edificio) y otros de los que solo tenemos indicios en las iglesias de Tricio, Ventas Blancas y Arlanza son coetáneos a sus obras y abonan por una cierta reiteración de su presencia. La escasez y debilidad de los indicios impide asegurar su verdadera importancia decorativa y su grado de relación con los constructores. Pero tanto las bóvedas, por el material utilizado, como en ocasiones, los paramentos interiores de ábsides y aulas, porque los sillares no se recortaron (Arlanza, Ventas Blancas, Tricio, Santa Coloma), necesitaban revestirse. Estas superficies se ocultarían por una gruesa capa de estuco decorado, indicando que este revestimiento estaría vinculado, al menos en ciertos casos, a la sillería reutilizada. La ausencia de la escultura en piedra y la presencia de la estucada se explican mutuamente. Solo en algún caso excepcional se preferiría la decoración esculpida en piedra a la tallada o moldeada en estuco, como en Quintanilla. La mejor superviviencia y el mayor impacto de la esculpida en piedra han facilitado que se ignorara la estucada. Condiciones de carácter técnico y económico, como su realización más sencilla, rápida y barata, una organización social diferente, aldeana frente a la urbana de los talleres surgidos en las metrópolis de Mérida y Toledo en los siglos VIII y IX, y la ausencia/ existencia de talleres y operarios expertos facilitarían la primacía de los talleres de estucadores sobre los de escultores. 
El taller escultórico en piedra de Quintanilla está formado por mano de obra ambulante, contratada para una producción directa sobre el edificio y no "prefabricada" previamente en un taller alejado y urbano. La decoración se talla con la sillería puesta en obra y aprovechando sus andamios. Así se talló toda la decoración, tanto la exterior como la interior (frisos e impostas/capiteles del ábside). El taller decorativo depende de su coordinación con el taller constructivo (directamente o a través del promotor de la obra), asumiendo un compromiso temporal para realizar una producción extraordinaria que no se concluye. El taller es exclusivo; su decoración es más libre y apenas se somete a patrones formales repetitivos o esquemáticos; se distingue por decorar los paramentos externos; y su repertorio posee un carácter de unicum. Al no contar con núcleos urbanos donde implantarse, consolidar y distribuir su producción, su ciclo productivo se agota, desde nuestra perspectiva actual, apenas en una obra singular, con un escaso eco en producciones locales y secundarias. Las marmolerías de las ciudades de Mérida y Toledo, que sirvieron a edificios como El Trampal y Melque y a otros de sus ciudades y territorios en los siglos VIII y IX, o las de Oviedo no se relacionaron con el grupo productivo de La Rioja y Burgos, impedidas de rebasar sus límites cronológicos y territoriales (Caballero 2013; Utrero, Murillo, Martín, Rielo, Villa, Moreno, Álvarez y Baltuille e.p.).

La producción escultórica de Quintanilla manifiesta otras características diferenciadoras. Una es la ausencia de impostas molduradas o decoradas y asociadas a estructuras abovedadas. Ninguno de los edificios del grupo principal ni de los asociados (bóvedas de cañón de Siero, Gormaz, Pedro) ofrece estas molduras. Su ausencia impide su uso indiciario de la existencia de bóvedas, al contrario de lo que ocurre en otros grupos constructivos altomedievales (Mérida, Toledo, La Nave, Asturias. Caballero 2013). Solo un pequeño fragmento de friso, citado antes, que se diferencia por su menor altura de los frisos del grupo exterior al que sin embargo pertenece por su dibujo y talla, es posible que tuviera una función distinta que pudo ser la de imposta de las bóvedas de cañón, aunque ningún indicio positivo lo asegura (Fig. 26a, en caliza blanca, procede de un terreno colindante con la ermita, documentado por Ordax y Abásolo 1982: lám. 22, pieza inferior, $(14 \times 13 \times 6) \mathrm{cm}$, altura supuesta $17 / 19$ frente a los $45 \mathrm{~cm}$ de los frisos). Solo se conocen cornisas coronando los muros exteriores en S. Vicente del Valle, decorada, y en Santa Coloma, lisa.
La segunda característica es la ausencia de canceles decorados. Este rasgo no es exclusivo de su grupo pues, como conocemos, se asimila también a la iglesia de La Nave. Conocemos dos soportes del altar de Quintanilla, excepcionalmente fabricados en mármol, encuadrado en el tipo evolucionado altomedieval (Melque, El Trampal, La Nave).

Aunque la decoración exterior y la interior de la iglesia de Quintanilla pertenecen a distintos modelos y tallistas, se unifican como dos grupos de un mismo taller por su misma técnica y compaginar algún modelo (roleos con pájaros). Para proceder de distintos talleres deberían diferenciarse por unas técnicas de producción distintas. Tanto la epigrafía y la decoración exterior (por estar inacabada) como la interior (por los marcos distales sin tallar de los capiteles) se realizaron una vez colocada la sillería, lisa, en obra. Al pertenecer ambos grupos al mismo taller, no se puede argumentar que se interrumpió la decoración en el exterior y se reanudó en el interior varios siglos después. Se debe aceptar que el edificio se decoró e inscribió una vez terminada su construcción y que entonces quedó inacabado el proceso de decoración y de inscripción, bien fuera en el interior o en el exterior. Nada impide considerar que arquitectura, decoración y epigrafía, exterior e interior, son unitarias y coetáneas (Camps 1939-1940: 28; Schlunk y Hauschild 1978: 230 y 233. Harris 2003: 121-130 considera, sin argumentarlo, que los frisos de Quintanilla se asemejan a los de la iglesia siria de Dayr Siman, finales del siglo $\mathrm{V}$, y que no se tallaron in situ, sino en un taller).

Ello no impide que este taller decorativo de Quintanilla, unitario, ofrezca grupos y variantes productivas, pertenecientes a manos y tallistas distintos. Un tallista labró el grupo formado por los frisos exteriores, aunque quizás decoró en el interior las impostas de las bóvedas. Otro decoró el grupo del arco del ábside que quizás se extendía a otras piezas que iban desde la portada occidental al crucero. A estos grupos principales se pueden añadir variantes de otros tallistas de menor habilidad o calidad diferenciados a partir de algunas piezas sueltas. Sin embargo dada la descontextualización de estas piezas y las excepciones que presentan, debemos considerar la posibilidad de que pudieran pertenecer a otros edificios vecinos a la iglesia. Los seis fragmentos de frisos con roleos son similares al grupo exterior de la iglesia aunque su dibujo es de calidad ligeramente inferior y su forma de losa corresponde a un aparejo diferente al conocido de la iglesia, como ya hemos dicho. Otros tres fragmentos pueden indicar la existencia de un tercer 
tallista de dibujo menos ágil y esquema compositivo más rígido. Una de las piezas, reutilizada en la iglesia, se decora a eje con dos palmetas y dos racimos que surgen de un tronco sogueado, simulando una palmera, encerrado el motivo por un listel (Fig. 26b. Muro de cierre del paso del aula al crucero. Ordax y Abásolo 1982: lám. 23, en el centro, aproximadamente 0,5 x 0,6 $\mathrm{cm})$. Los otros dos fragmentos proceden de Quintanilla y del monasterio de Valeránica, célebre por su escritorio y situado a $40 \mathrm{~km}$ de Quintanilla (Fig. 26c y d. En el museo de Burgos. Quintanilla, Ordax y Abásolo 1982: lám. 23, abajo, $(39$ x 23) x 23,5 cm. Yacimiento de Tordómar, prov. de Burgos, Williams 1970: taf. 72a, $44,5 \times 33 \times 13,5 \mathrm{~cm})$. Ambas piezas están talladas en piedra arenisca, rojiza y gris, frente al uso general de piedra caliza. Presentan "árboles de la vida", un tema a eje, en la de Quintanilla encerrado en un círculo sogueado y en la de Valeránica como remate de un friso limitado por un listel. El tema imita los frisos exteriores de Quintanilla pero su tratamiento demuestra la incapacidad de copiarlos con fidelidad al complicar el esquema, desfigurar los elementos que lo componen, ramas, triples hojas y racimos, y exagerar el uso de las incisiones para los sogueados y para figurar troncos.

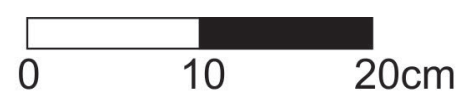

Dimensiones aproximadas para las figuras "b" a "e"
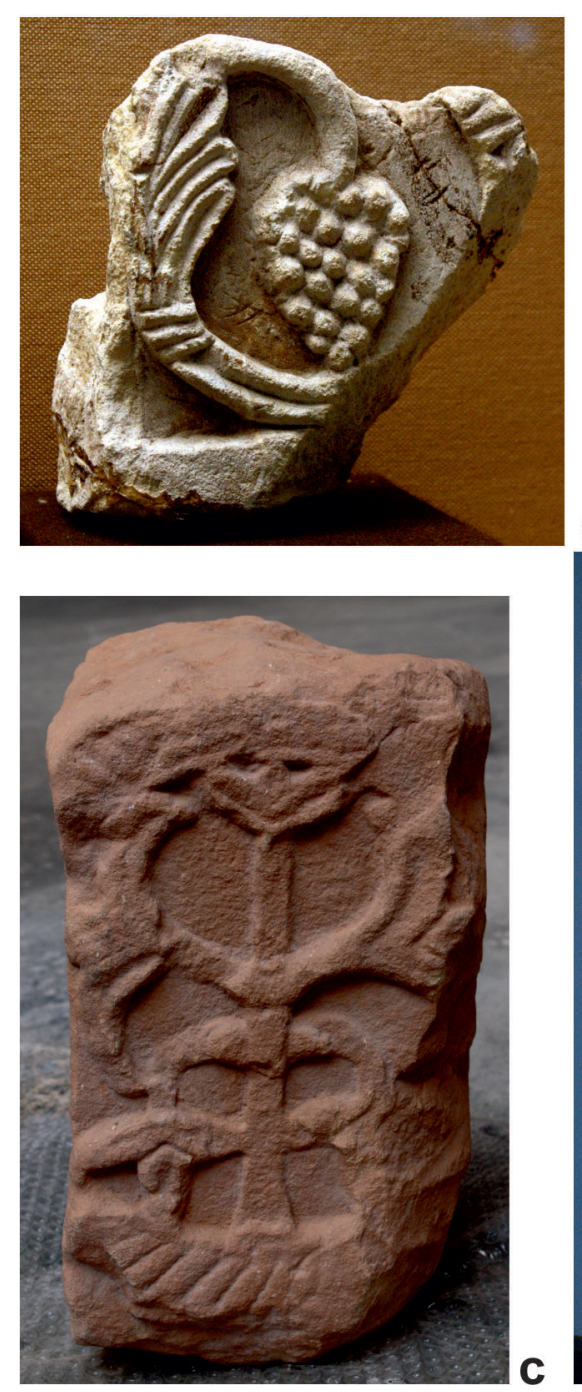
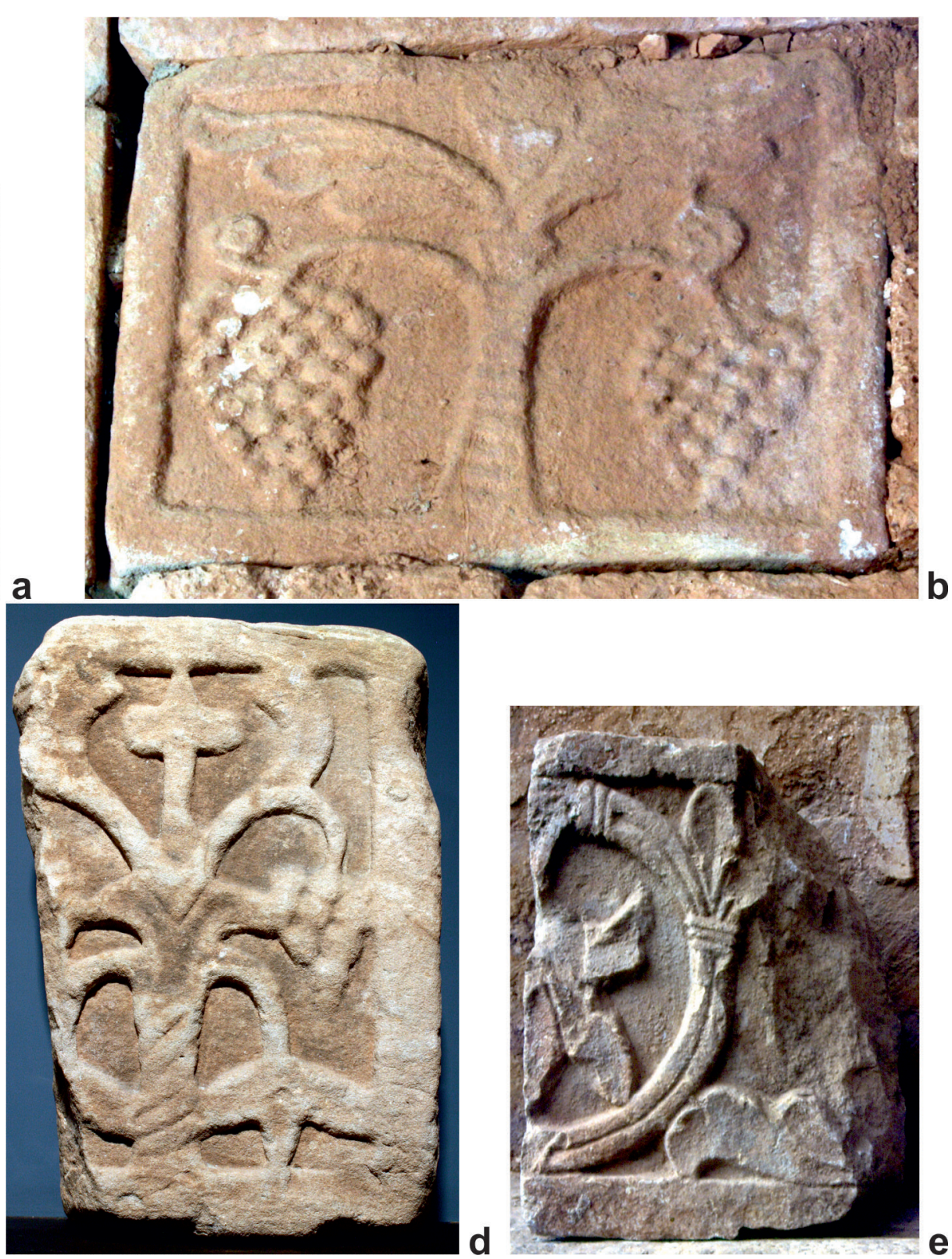

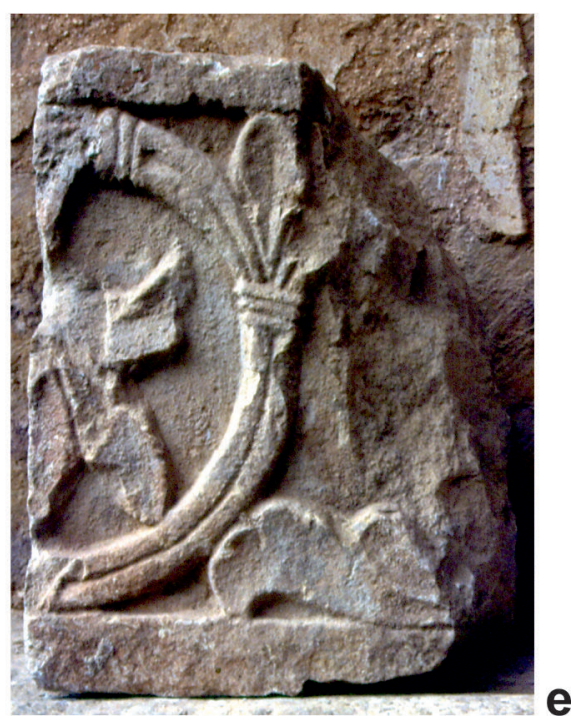

Figura 26.- Fragmentos de friso. a, b y c, Quintanilla de las Viñas (a y c en el Museo de Burgos); d, Valeránica (Tordómar, prov. Burgos; Museo de Burgos); e, San Pedro de Arlanza (Burgos), refectorio. Escala aproximada . La pieza a está al doble de su tamaño relativo. 
Así, por una parte se asegura la presencia de un taller que reparte entre sus tallistas las zonas a decorar de la iglesia o quizás de otros edificios. Los de superior habilidad decoran las zonas más simbólicas de la iglesia (con frisos y figuras) y los de inferior calidad, seguidores del tallista de los frisos exteriores del ábside, zonas hoy perdidas de la iglesia u otros edificios. Por otra parte, la pieza de Valeránica y otra reutilizada en un muro medieval del monasterio de San Pedro de Arlanza (Fig. 26e. Muro de celdas del refectorio, inédita), plantean la posible producción de otras obras similares a la de Quintanilla, coetáneas y en su inmediato territorio ( $\mathrm{Al}$ margen del fragmento de posible friso de imposta, Fig. 26a, al que ya hemos hecho referencia; nos faltan por señalar un fragmento al parecer decorado con un ave y sogueado, conservado en el Tabularium Artis Asturensis de Oviedo, desconocido por nosotros, citado por Barroso y Morín
2001: 60; otro con la decoración borrada, conservado en la iglesia del pueblo, Andrés y Abásolo 1982: lám. 23; y otro conservado en la fachada de una casa del pueblo, inédito. La iglesia y la cerca del cementerio están construidas con material procedente de la ermita).

Los dinteles de ventana, arcuados y decorados con "árboles de la vida" de Siero y Elines defienden una irradiación del estilo de Quintanilla, en edificios que se asemejan técnicamente al del grupo de bóvedas de pechinas en piedra de toba. Abogan por la existencia de artesanos aislados cuyas semejanzas formales dependerían de una formación vinculada al taller de Quintanilla. Los alfices de las piezas de Elines denotan una cronología más avanzada. Los principios de la producción hacen insostenible la tradicional explicación "visigotista" que defiende una separación de doscientos o más años entre estas producciones (Fig. 27. Noack 1987: 585-586; Arbeiter y Noak

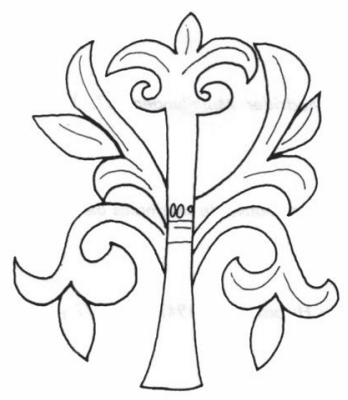

a

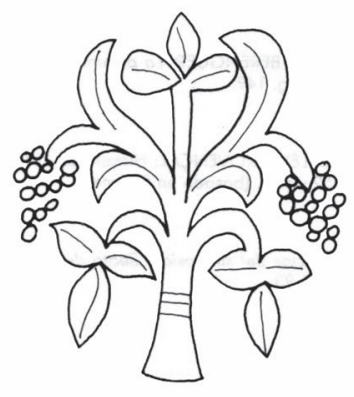

d

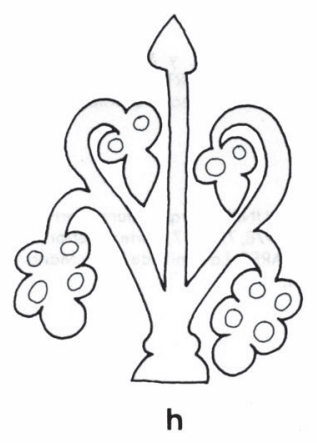

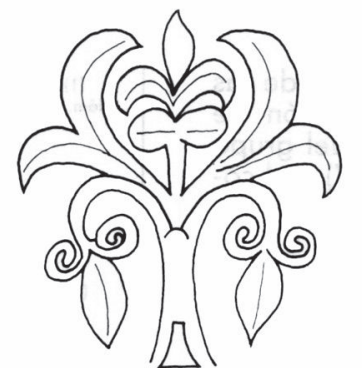

b

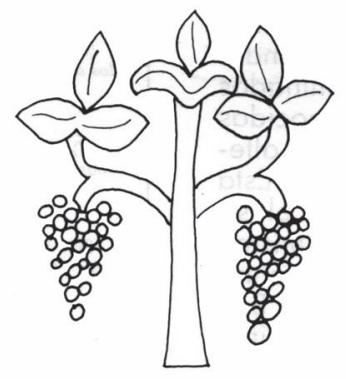

e

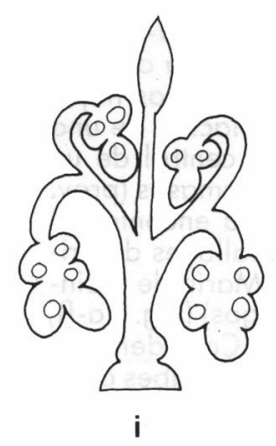

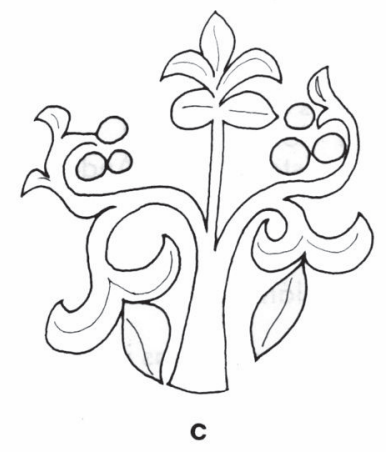
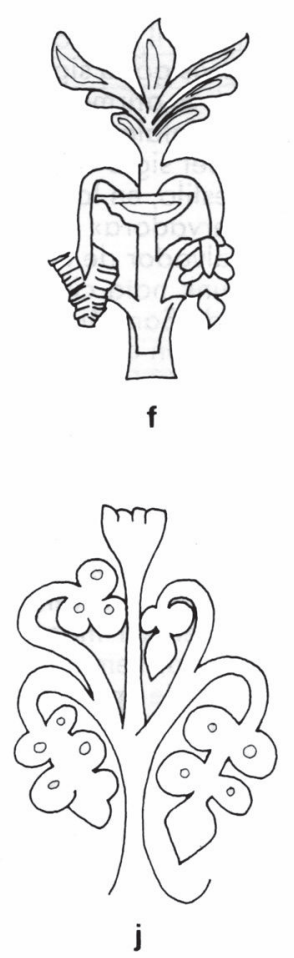

Figura 27.- Detalles decorativos, a-f, Quintanilla; h-i, ventanas de San Martín de Elines (Valderredible, prov. Cantabria); j, ventana de Siero (según Noak 1987). 
1999: 327-330). Todas ellas dependen de un mismo ambiente técnico y han de ser inmediatas, entre finales del s. IX y la primera mitad del s. X o poco más.

La misma excepcionalidad de la decoración esculpida de Quintanilla es característica de los capiteles de San Vicente del Valle 2. La bibliografía sobre estos capiteles refleja la duda de si procedían de un expolio y fueron realizados siglos antes o si su realización fue coetánea y encargada para la iglesia. Resolver este dilema a favor de su fabricación coetánea, como nosotros suponemos, confirmaría la llegada de tallistas excepcionales o, por comercio, de productos manufacturados a un ambiente productivo donde se ignora cómo se elaboran columnas y capiteles, como demuestra su sustitución por fustes, cornisas expoliadas (Oca), sillares con función de capitel (Quintanilla) o por un capitel de forma no clásica (procedente de Frías o Cillaperlata, prov. Burgos, Huidobro 1928-1929 y Noak 1987). Los cimacios/capiteles de Quintanilla recuerdan los de la tribuna de San Miguel de Lillo (Oviedo), que corresponden a la reforma de la fase originaria. No se pueden suponer ambos obra de un mismo taller constructivo, pero evidencian la similitud de soluciones técnicas, la incapacidad para realizar capiteles del taller que realiza la reforma y la simultaneidad de sus producciones. Algo parecido se puede decir de los capiteles de La Nave. La situación contrasta con la andalusí y en concreto con los capiteles figurados de Córdoba que creemos coetáneos de los de San Vicente del Valle y, en consecuencia, del grupo constructivo que estudiamos. Otra manifestación decorativa igual de excepcional es la del mosaico del ábside de Tricio. Como ocurre con las demás "excepciones" de este grupo, que hoy nos parezca única no nos obliga a considerar anacrónica su relación con la arquitectura a la que pertenece ni con el grupo productivo que tratamos. Estas producciones, estucos, escultura, capiteles, mosaico, son los indicios que nos quedan de los talleres decorativos que formaron parte o colaboraron con los talleres constructivos y que ayudan a comprender la identidad del grupo productivo. Aunque en la situación actual, estos productos no sirven como indicadores cronológicos "absolutos" de los edificios a los que pertenecen, su contextualización rompe la inmovilidad de su adscripción tradicional. Los problemas que presentan el mosaico de Tricio y los estucos de Santa Coloma recuerdan los similares de los estucos y mosaicos de otros edificios de los siglos VIII-IX (Melque, Villajoyosa. Caballero $2001 b$ y 2013).

\section{LA CUESTIÓN CRONOLÓGICA}

Cuando la iglesia de Quintanilla de las Viñas fue descubierta en 1927 por Huidobro, su análisis la hizo suponer de época visigoda (planta basilical con crucero, ábside cuadrado, sillería, arco de herradura, decoración, semejanza con La Nave, entre otras razones. Fig. 28). Al margen de datos de imposible comprobación o fabulados, esta adscripción fue contradicha de inmediato por la relación de la oferente del edificio con la Flammola histórica, afianzada por la que la tradición defendía entre la ermita y el monasterio de Santa María de Lara y, en consecuencia, con los documentos históricos que se refieren a ellos (Serrano 1925: documentos 2 falso y 3, de 912, y 5, de 929: 5-13 y 18-21; Huidobro 1927, tradición en la segunda mitad del s. XIV; Huidobro 1927-1928, se apoya en Prudencio de Sandoval, Gregorio de Argaiz y Flórez, siglos XVII-XVIII). Mientras que la relación entre los dos personajes se ha contestado, la equiparación entre monasterio y ermita se ha aceptado sin excepción (hasta hoy, del Hoyo e.p.). Flámola se sitúa entre fines del s. IX e inicios del X († p.q. 929), en el territorio de Lara, donde se encuentra la iglesia, y fue esposa del conde Gonzalo Téllez, de Lantarón, Cerezo y Lara, presunta hermana de Mumadona y, de ser así, cuñada del conde Gonzalo Fernández, de Burgos y Lara, y tía de Fernán González. Por ello se supuso una intervención altomedieval en el edificio (Orueta 1928 la supone obra visigoda; Huidobro 1927-1928, restaurada por la Flámola histórica; Porter 1928: 38-41, obra de Flámola en el primer cuarto del s. X). Posteriormente se afianzaron estas posturas. Por una parte, la unidad del edificio y el mantenimiento de la explicación "visigotista" obligaron a rechazar el valor histórico de los documentos, dado que a partir de ellos era imposible confirmar el s. VII como el de construcción del edificio (Camps 1939-1940 y 1940: 571-601). Y por otra, las dudas que mantenía la inscripción se procuraron resolver proponiendo, como en San Pedro de La Nave, la actuación de dos maestros decoradores, el segundo de los cuales, por encargo de Flámola, restauraría la iglesia y decoraría su crucero (Gómez Moreno 1966).

En los años 1935 y 1952 se realizan las excavaciones de la iglesia que ofrecen algunas piezas que apoyaban la datación visigoda: una jarra de bronce y dos fragmentos de un vaso de vidrio (ajuar en la habitación norte del porche) y abundante cerámica de tradición romana y otra visigoda (habitación sur). Hallazgos no documentados y, por lo tanto, sin un definitivo valor cronológico (Íñiguez 1955). 
En 1945 se pretendió demostrar la ineludible existencia de una desconocida miniatura de época visigoda de la que dependerían dos grupos decorativos conocidos, la escultura figurada "visigoda" considerada del s. VII (capitel de Córdoba; decoración de Baños, la Nave y Quintanilla) y la miniatura hispánica del s. X. El argumento definitivo para demostrar su existencia sería la cronología "visigoda" del capitel de Córdoba y de las zapatas de la inscripción de Baños. De esta manera no era necesario plantear que la similitud de los temas decorativos (escultura y miniatura) equivalía a su producción coetánea, pero se incurría en un argumento falaz y circular (Schlunk 1945).
Han sido múltiples los intentos de lectura de los anagramas de Quintanilla pero hasta el momento no ha sido posible conseguir su sentido correcto. Solo es seguro que corresponden a dos personas, dada la presencia de la conjunción et entre los dos primeros, que son sujetos del tercero, la forma verbal fecerunt (Caba1lero 1989; del Hoyo e.p.). Para los anagramas y para el busto de Cristo con nimbo crucífero de Quintanilla se ofrecieron paralelos en las monedas visigodas y otros anagramas de Constantinopla de fines del s. VII (Camps 1939-40; Schlunk y Hauschild 1978: 230-234).

La ausencia de un análisis paleográfico de la inscripción de Flámola se ha paliado recientemente

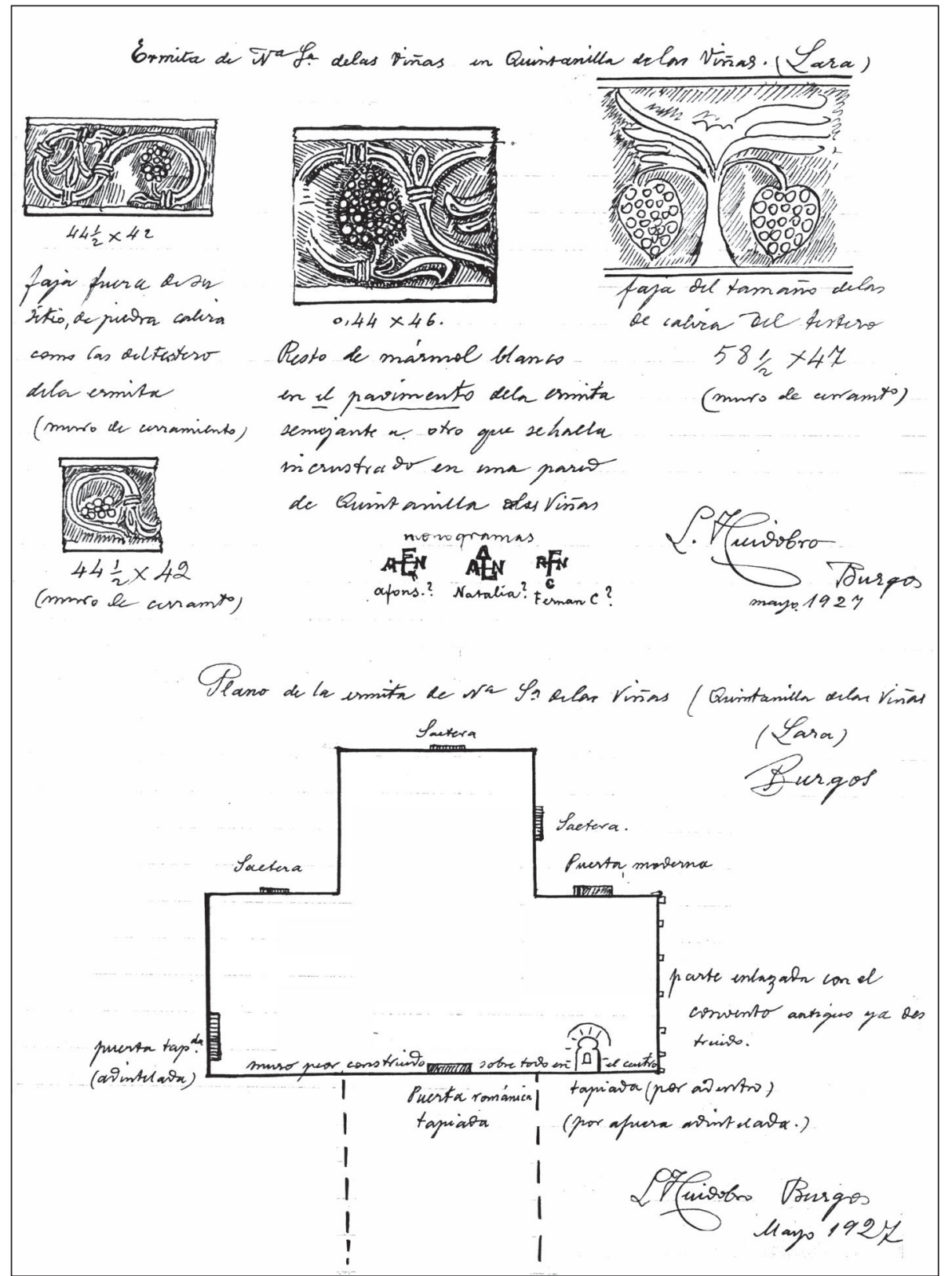

Figura 28.- Nota manuscrita de Huidobro sobre Quintanilla (1927. Cortesía de Manuel Casamar Pérez). 
defendiendo que su trazado es similar al habitual de los siglos VI y VII y está ausente en el panorama del s. X, concluyendo en consecuencia la datación visigoda del edificio (del Hoyo e.p.). Esta comparación no tiene en cuenta que las inscripciones tardoantiguas son incisas, mientras que estas son "en reserva", o en altorrelieve; técnica a lo que sabemos desconocida en el ámbito hispano tardoantiguo, lo que invalida su adscripción al s. VI/VII. Ya se ha puesto en relación esta manera de hacer propia del cancel de Lena (prov. Asturias) con la epigrafía andalusí y asturiana (Gómez Moreno 1966; Real 2007: 168, para Asturias s. XI. También Schlunk y Hauschild 1978: 196-197, lám. 96, al tratar el “capitel" de Bernardos, Museo de Segovia, que datan en el s. VII, aunque debe considerarse también de época altomedieval, comparan la técnica de su inscripción y su cruz con las inscripciones de Lena, Quintanilla y Siero).

Otro dato que interesa para la datación altomedieval de la fórmula de la inscripción dedicatoria de Flámola es su relación con la también dedicatoria que, con otra de renovación, ambas perdidas, se situaba a un lado del altar mayor de la basílica de San Salvador de Oviedo, en una situación, salvando las diferencias, similar a la de Quintanilla. San Salvador fue renovado por el rey Alfonso II entre 796/808 y 842, aproximadamente un siglo antes de la fecha que proponemos para la de Flámola en Quintanilla. Discutida, como su compañera, por apócri$\mathrm{fa}$, en la actualidad se consideran ambas auténticas. El texto que interesa dice:

... tibi Domine tibi tua offerimus. Huius / perfectam fabricam templi exiguus servus / tuus Adefonsus exiguum tibi dedico / muneris votum...

Frente a la larga tradición tardoantigua del término servus, exiguus sería utilizado a partir de Alfonso II, así como otros similares como vernulus y humilis. La misma idea aparece en el documento de donación de Flámola al monasterio de San Pedro de Arlanza en el año 912:

\section{... pro magis offerimus munuscula nullusque...}

(Citados en relación con Quintanilla, inscripción y documento por Puig i Cadafalch 1961: 136; e inscripción por Pérez de Urbel 1969-1970: 46, n. 22; y Sepúlveda 1986. La inscripción citada por Schlunk 1978-1980 en relación con la dedicación de la cruz de los Ángeles.
Estado de la cuestión de las inscripciones de Oviedo en García de Castro 1995: 177-179, n. ${ }^{\circ}$ s 21 y 22).

Son falsas las noticias de unas desaparecidas inscripciones procedentes de los alrededores de Quintanilla y de un supuesto Becerro de Santa María de las Viñas que datarían la restauración y consagración de la iglesia por un obispo Almiro en el año 879 (Huidobro 1928-29; Gómez Moreno 1966; crítica por Camps 1939-40; y Escalona 2002). Y es una interpolación la donación que figura en el testamento del abad Avito (822/952) de una iglesia de Santa María de Lara al monasterio de Tobillas (cuya iglesia pertenece al grupo que tratamos), que se refiere a otra iglesia diferente de la burgalesa (Peña 1993; Pastor 1996: 127-128; crítica por Larrea 2007).

Los dos documentos de 912 y un tercero de 929 que se refieren a Flámola y a los monasterios de Arlanza y Lara, presentaban una contradicción entre ellos que recientemente se ha solucionado al considerar falso uno de los dos de 912. En el que se considera verdadero, el conde Gonzalo Téllez y Flámola confirman la fundación y dotan el monasterio de S. Pedro de Arlanza. Años después, en 929, Mumadona y su hijo Fernán González emancipan la comunidad de monjas del monasterio de Santa María de Lara. O sea, en el primer decenio del s. $\mathrm{X}$, el conde Gonzalo Téllez, esposo de Flámola, detenta el poder de facto en Lara, fundando el monasterio de Arlanza, cuya iglesia, razonablemente, es la de San Pedro de Arlanza. En el mismo plazo temporal se puede suponer la intervención de Flámola promoviendo el monasterio de Santa María de Lara, cuya iglesia es la de Quintanilla. En un momento inmediato posterior, la influencia de esta pareja en el condado de Lara es sustituida por la de Gonzalo Fernández, su esposa Mumadona y su hijo Fernán González. Por ello es Mumadona y no Flámola la que interviene en 929 en Lara. La unidad constructiva, decorativa y epigráfica de la iglesia de Quintanilla, ya demostrada, impide suponer una restauración y permite asimilarla a los datos de la documentación escrita a través de la figura de Flámola. Las iglesias de Quintanilla y Arlanza, que pertenecen al mismo grupo constructivo y son coetáneas, habrían sido fundadas por el conde Gonzalo Téllez y su esposa Flámola (aceptada su relación con el documento y la inscripción), en el primer decenio del s. X (Serrano 1925; Escalona 2002; Escalona, Azcárate y Larrañaga 2002. Escalona, a pesar de explicar en este sentido los documentos, defiende la construcción visigoda de Quintanilla basándose en el continuismo y bizantinismo de la construcción, en el pobre panorama cultural altomedieval y en una restauración de la iglesia 
que, sin embargo, cree difícil de demostrar). La iglesia de Tobillas, perteneciente al mismo grupo productivo aunque sin ninguna relación con los promotores de las de Arlanza y Lara, se construyó por el abad Avito entre medio siglo o quizás un siglo antes, a.q. 822/852, en coherencia con el proceso de ocupación del territorio. Queda una pregunta por contestar: a quiénes pertenecían los monogramas del testero de Quintanilla y en función de qué se les dedicaron.

A pesar de la presión ejercida por la hipótesis "visigotista", la defensa de la cronología altomedieval de Quintanilla fue perseverante. En la década de 1960 se aprovechó la argumentación aparentemente desechada (homogeneidad productiva y documentación escrita) para procurar trasladar la datación de toda la arquitectura considerada "visigoda" al s. X. Sin embargo, la excepción de Baños, cuya datación epigráfica (661d. C.) se consideraba inalterable, obligó a aceptar la existencia de una arquitectura visigoda con similares características a la considerada del s. X, provocada por una corriente artística continuista y "visigotista" (antes Porter 1928 y Witehill y Clapham 1937; Puig i Cadafalch 1961 y Camón 1963). Hoy se ha puesto en duda la datación epigráfica automática de Baños y se considera que el argumento continuista es imposible por el principio de la unidad productiva que obliga a una paralela unidad cultural y cronológica. Así, a partir de 1994 se lleva este razonamiento a sus últimas consecuencias proponiendo un modelo explicativo "rupturista" debido a la llegada a la Península de una nueva cultura, la islámica, con el cambio de cronología. Un argumento básico en este modelo explicativo es el de que las iglesias de La Rioja y Burgos, con la de Quintanilla, forman un grupo productivo imposible de dividir en dos momentos históricos separados por el año 711 (Caballero 1994-95 y 2001a).

En el mismo año de 1994 se estudió y restauró la iglesia de Tobillas. Nos interesa la datación de su primera etapa que pertenece al grupo que ahora estudiamos. Se construyó sobre las ruinas de un edificio romano, sin que conste la existencia de niveles intermedios de época visigoda. El nivel que corta las fosas de fundación de la iglesia originaria está datado por cerámicas "de repoblación". Por otra parte, de acuerdo con el testamento del abad Avito (822 o 852) se puede afirmar que la iglesia fue construida en el s. IX. La segunda etapa de dicha iglesia se documenta por una inscripción encontrada en su excavación, la cual informa que el presbítero Vigila restauró la iglesia en el año 939 con una técnica constructiva distinta a la de la primera, especialmente con sillería de cantera (Azkarate 1995; Sánchez Zufiaurre 2007). Ambas fechas son los márgenes cronológicos del grupo constructivo al que pertenece Tobillas 1, entre los primeros decenios del s. IX y los del s. X. Desde la lógica de la producción constructiva y dada la homogeneidad tecnológica y formal del grupo, es difícil atrasar su cronología a inicios del s. VIII y es inaceptable llevarla hasta el s. VII. A este periodo altomedieval se ajustan las demás datas documentales; las características constructivas de los grupos constructivos con que se pueden comparar, bizantino y omeya musulmán; y la utilización de otras bóvedas hispánicas construidas con piedra toba durante los siglos IX al XI (Utrero 2006: 235-236).

$\begin{array}{ll}\text { Siero } & (777) \\ \text { Tobillas I y II } & 822 / 852 \text { y } 939 \\ \text { Oca } & \text { a.q. } 863 \\ \text { Quintanilla } & \text { a.q. } 912 \\ \text { Arlanza } & \text { a.q. } 912 \\ \text { Santa Coloma } & \text { a.q. } 923 \\ \text { Tabladillo } & \text { a.q. } 924\end{array}$

Se debe estimar la inexactitud de la fecha de Siero (777), borrada intencionadamente y difícil de suponer anterior al grupo por consideraciones de lógica productiva, tanto constructiva como decorativa. Oca pudo ser construida por el conde Diego Porcelos, quien la donó al abad Severo en 863, confirmando la donación en 883 (Huidobro 1928-29; Uranga e Íñiguez 1971: 41-42). Santa Coloma se documenta como restaurada por el rey Ordoño II en 923, por lo que se supuso que se debería a él la decoración de estilo musulmán obtenida entre los Banu Qasi de Zaragoza, pero se debe considerar que edificio y decoración son coetáneas (Uranga e Íñiguez 1971: 37-39; Arbeiter y Noack 1999: 354-357). Tabladillo, se documenta como parroquia en el año 924 (Carretón 1992).

La datación de la alta Edad Media ha sido defendida también con argumentos de Historia del Arte, referidos a su decoración. El estudio de los relieves de Quintanilla solucionaría la tradicional indefinición de su ubicación cronológica entre los siglos VII y X, demostrando que sus orígenes remotos son la Persia sasánida y el Mediterráneo oriental, pero transmitidos a través de la cultura islámica (Córdoba, siglos IX y X). Así lo indicarían las diferencias técnicas y formales con los supuestos paralelos coptos, sirio-palestinos y sasánidas tardíos, que suponen una revitalización de lo sasánida en los siglos VIII y X. El foco común fue el núcleo difusor 
del Islam y el supuesto bizantinismo corresponde al fundamento oriental sasánida y tardomediterráneo de la cultura islámica. Por otra parte, no es lógico suponer un precedente en una miniatura visigoda de existencia no demostrada. Se concluye aceptando que fuera Flámola la promotora de la iglesia de Quintanilla en la primera mitad del s. X y en un ambiente artístico análogo al de la iglesia de San Miguel de Escalada (Cruz 2002-2003 y 2004; Utrero e.p.; argumentos que inutilizan otros como los de Grondjis 1952; y Garen 1997).

Encuadrar la paleografía de las inscripciones de Quintanilla en el s. VII e inicios del VIII y equiparar sus monogramas con los de las monedas visigodas (entre 649-700) son consideraciones que no encajan con el modelo que defendemos y los argumentos que exponemos aquí. A ello se añade la opinión de que la relación entre las dos Flámolas (histórica y epigráfica) y los dos edificios (monasterio y "ermita") no es manifiesta (del Hoyo e.p.). Pero, si aceptamos que la iglesia de Quintanilla se construyó en el s. X, es evidente que las particularidades de los documentos y los edificios se acomodan sin contrariarse; y la iglesia del monasterio de Arlanza se construyó en el mismo territorio, con los mismos actores y como un producto similar. Si aún así quisiéramos salvar este salto, la homogeneidad que manifiesta el grupo al que pertenecen sitúa ambas iglesias en el mismo escenario sin que sea necesario recurrir a los documentos y a las tradiciones toponímicas para adscribirlas al mismo contexto tecnológico, cultural y cronológico. Las características paleográficas se manifiestan como el único obstáculo, a la espera de que puedan acomodarse debidamente pues, de acuerdo con el principio de la unidad productiva, también deben pertenecer al mismo momento. Dado que arquitectura, decoración y epígrafes tienen el mismo encuadre cronológico-cultural, habrá que resolver la aparente excepción que provoca la paleografía.

\section{AGRADECIMIENTOS Y FICHA TÉCNICA}

Agradezco los muchos comentarios y observaciones, en ocasiones alargados durante años, debidos a Leandro Cámara, María de los Ángeles Utrero, Fernando Arce, Francisco Moreno, Helena Gimeno, Julio Escalona y Alejandro Villa. Agradecemos también al recordado Manuel Casamar Pérez, la figura 27. A Javier del Hoyo y María de los Ángeles Utrero, el conocimiento de sus manuscritos. A Rafael Martín Talaverano, los dibujos reconstructivos de Quintanilla. Y, la ayuda prestada a Marta Negro Cobo, directora, y Belén Castillo Iglesias, conservadora, del museo de Burgos, y a Antonio Velasco García, guarda del monumento de Quintanilla.

Este trabajo es resultado del proyecto de investigación "Análisis arqueológico de la arquitectura altomedieval en Asturias (II)", HAR2011-27579, del que el autor es investigador principal.

Las fotos en el museo de Burgos se han efectuado con el permiso del Servicio Territorial de Burgos, Consejería de Cultura y Turismo, de la Junta de Castilla y León.

La autoría de figuras consta en sus pies; excepto en aquellas que son del autor del texto.

\section{ANEXO}

Se acompaña el modelo 3D de la reconstrucción de la iglesia de Quintanilla en la versión html on line. Dibujo de Rafael Martín Talaverano.

\section{FUENTES PRIMARIAS}

"Pedro. Ermita de la Virgen del Val" [en línea] www.soriaromanica.es/es/ iglesias [consultado 19/11/2014].

\section{BIBLIOGRAFÍA}

Andrés Ordax, S. y Abásolo Álvarez, J. A. 1982: La ermita de Santa María. Quintanilla de Las Viñas (Burgos). Burgos.

Andrés Valero, S. 1983: "Excavaciones de Sta. María de Los Arcos (Tricio, La Rioja)", I Coloquio sobre Historia de La Rioja, Cuadernos de Investigación. Historia, 9, pp. 113-126.

Aparicio Bastardo, J. A. y Fuente, A. de la. 1993-1994: "Estudio arqueológico e intervención arquitectónica en la iglesia de la Asunción de San Vicente del Valle (Burgos)", Numantia, 6, pp. 153-171.

Aparicio Bastardo, J. A. 2000: "Los capiteles prerrománicos de la iglesia de La Asunción. San Vicente del Valle (Burgos)", Revista de Arqueología, 235, pp. 50-55.

Aparicio Bastardo, J. A. 2007: "Recuperación de un capitel altomedieval en Villafranca Montes de Oca (Burgos)", Boletín de Arqueología Medieval 13, 257-266.

Arbeiter. A. 1990: "Die westgotenzeitliche Kirche von Quintanilla de las Viñas. Kommentar zur architektonischen Gestalt", Madrider Mitteilungen, 31, pp. 393-427.

Arbeiter, A. y Noak-Haley, S. 1999: Christliche Denkmäler des frühen Mittelalters. Mainz am Rhein.

Arbeiter, A. 2001: "II. Disposición y construcción del templo", en R. Barroso y J. Morín, La iglesia de Santa María de Quintanilla de las Viñas: pp. 45-78. Arce Sainz, F. 2010: "La iglesia alto medieval de la Asunción en San Vicente del Valle (Burgos): historiografía, estratigrafía e interpretación”, Arqueología de la Arquitectura, 7: pp. 67-103. 
Arias Páramo, L. 2012: "Geometría, metrología y proporción en la arquitectura altomedieval de la meseta del Duero", en L. Caballero, P. Mateos, y C. García de Castro (eds.), Asturias entre visigodos y mozárabes, Anejos de AEspA LXIII, pp. 353-390. CSIC, Madrid.

Azkarate Garai-Olaun, A. 1995: "Aportaciones al debate sobre la arquitectura prerrománica peninsular: la iglesia de San Román de Tobillas (Álava)”, Archivo Español de Arqueología, 68, pp. 189-214.

Balado Pachón, A., Escribano Velasco, C. y Heras Fernández, E. 2008: "Las actuaciones arqueológicas", en San Miguel de Gormaz. Plan integral para la recuperación de un edificio histórico, pp. 29-72. Junta de Castilla y León.

Barroca, M. J. 1990: “Contribução para o estudo dos testemunhos pré-românicos de Entre-Douro-e-Minho. A. Ajimezes, gelosias e modilhões de rolos", en IX Centenário da dedicação da Sé de Braga, vol. I, pp. 101-145.

Barroso Cabrera, R. y Morín de Pablos, J. 2001: La iglesia de Santa María de Quintanilla de las Viñas. Madrid.

Caballero Zoreda, L. y Latorre Macarrón, J. I. 1980: La iglesia y el monasterio visigodo de Santa María de Melque (Toledo). Arqueología y arquitectura. San Pedro de La Mata (Toledo) y Santa Comba de Bande (Orense), Excavaciones Arqueológicas en España, 109. Madrid.

Caballero Zoreda, L. 1989: "Pervivencia de elementos visigodos en la transición al mundo medieval. Planteamiento del tema", en III Congreso de Arqueología Medieval Española, vol. I, pp. 113-134.

Caballero Zoreda, L., Cámara Muñoz, L., Latorre González-Moro, P. y Matesanz Vera, P. 1991-1992: "La iglesia prerrománica de San Pedro el Viejo (Hortigüela, Burgos)", Numantia, 5, pp. 139-165.

Caballero Zoreda, L. 1994-95: "Un canal de transmisión de lo clásico en la alta Edad Media española. Arquitectura y escultura de influjo omeya en la Península Ibérica entre mediados del s. VIII e inicios del X”, Al-Qantara, 15, pp. 321-348, y 16, pp. 107-124.

Caballero Zoreda, L. y Cámara Muñoz, L. 1995: "Un caso de lectura de paramentos y argumentación científica. S. Pedro el Viejo de Arlanza, BurgosEspaña”, Informes de la Construcción, 46, pp. 79-89.

Caballero Zoreda, L. y Arce, F. 1997: "La iglesia de San Pedro de La Nave (Zamora). Arqueología y arquitectura", Archivo Español de Arqueología, 70, pp. 221-274.

Caballero Zoreda, L. y Feijoo Martínez, S. 1998: "La iglesia altomedieval de San Juan Bautista en Baños de Cerrato (Palencia)", Archivo Español de Arqueología 71, pp. 181-242.

Caballero Zoreda, L. y Sáez Lara, F. 1999: La iglesia mozárabe de Santa Lucía del Trampal, Alcuéscar (Cáceres). Arqueología y arquitectura, Memorias de Arqueología Extremeña, 2. Junta de Extremadura, Mérida.

Caballero Zoreda, L. 2001a: “Aportación a la arquitectura medieval española. Definición de un grupo de iglesias castellanas, riojanas y vascas", en $V$ Congreso de Arqueología Medieval Española (Valladolid, 1999), vol. 1, pp. 221-233.

Caballero Zoreda. L. 2001b: "La arquitectura denominada de época visigoda, ¿es realmente tardorromana o altomedieval?, en L. Caballero y P. Mateos (eds.), Visigodos y Omeyas. Un debate entre la Antigüedad tardía y la alta Edad Media, Anejos de AEspA 23, pp. 207-248.

Caballero Zoreda, L., Arce, F. y Utrero, M. Á. 2003: "Santa María de los Arcos de Tricio (La Rioja), Santa Coloma (La Rioja) y La Asunción de San Vicente del Valle (Burgos). Tres miembros de una misma familia arquitectónica”, Arqueología de la Arquitectura, 2, pp. 81-85.

Caballero Zoreda, L. y Arce, F. 2004: “Arqueología de la Arquitectura de la iglesia de La Nave", en L. Caballero (coor.) La Iglesia de San Pedro de la Nave (Zamora), pp. 115-197. Zamora.

Caballero Zoreda, L., Arce Sainz, F. y Utrero Agudo, M. Á. 2004: "La iglesia de San Torcuato de Santa Comba de Bande (Orense): Arqueología de la Arquitectura", Archivo Español de Arqueología, 77, 273-318.

Caballero Zoreda, L. y Utrero Agudo, M. a Á. 2005: "Una aproximación a las técnicas constructivas de la Alta Edad Media en la Península Ibérica. Entre visigodos y omeyas", Arqueología de la Arquitectura, 4, pp. 169-192.

Caballero Zoreda, L. 2013: "Producciones constructivas y decorativas. Indicadores cronológico- culturales de la alta Edad Media hispánica”, Archivo Español de Arqueología, 86, págs. 187-214. doi: http://doi.org/10.3989/ aespa.086.013.011.
Camón Aznar, J. 1963: “Arquitectura española del siglo X. Mozárabe y de la Repoblación”, Goya, 52, pp. 206-219.

Camps Cazorla, E. 1939-1940: "El visigotismo de Quintanilla de las Viñas", Boletín del Seminario de Estudios de Arte y Arqueología de Valladolid, 6, 125-134.

Camps Cazorla, E. 1940: "El arte hispanovisigodo", en Menéndez Pidal (dir.) Historia de España, vol. 3, pp. 577-601. Madrid.

Cancela Ramírez de Arellano, M. ${ }^{a}$ L. 1986: "Santa María de Arcos, Tricio (La Rioja): campañas 1984-1986”, Boletín. Museo de Zaragoza, 5, pp. 289-295.

Cancela Ramírez de Arellano, M. ${ }^{a}$ L. 1992: Ermita de Santa María de Arcos. Tricio (La Rioja), Estrato, 4, pp. 42-46.

Carretón Hierro, D. E. 1992: La ermita mozárabe de Santa Cecilia. Valladolid.

Casa Martínez, C. de la. e Izquierdo Bertiz, J. M. a 1992: “Aproximación al hábitat visigodo de Tiermes”, en Actas del II Symposium de Arqueología Soriana (Colección Temas Sorianos), 20, t. II, pp. 1007-1019. Soria.

Conant, K. J. 1955: Arquitectura carolingia y románica. 800/1200. $3^{\text {a }}$ ed. Madrid. (1959: Carolingian and Romanesque Architecture. 800 to 1200. Hardsmonth).

Cruz Villalón, M. a 2002-2003: "Quintanilla de las Viñas y el arte cordobés", Norba, 22-23, pp. 341-348

Cruz Villalón, M. ${ }^{\text {a }}$ 2004: "Quintanilla de las Viñas en el contexto del Arte Alto medieval. Una revisión de su escultura", Antigüedad y Cristianismo, 21, pp. 101-135.

Cruz Villalón, M. ${ }^{\text {a } 2009: ~ " E l ~ p a s o ~ d e ~ l a ~ A n t i g u ̈ e d a d ~ a ~ l a ~ E d a d ~ M e d i a . ~ L a ~}$ incierta identidad del arte visigodo", en M. del C. Lacarra (coor.), Arte de épocas inciertas: de la Edad Media a la Edad Contemporánea, pp. 7-45. Zaragoza.

Domínguez Bolaños, A. 2003: "La documentación arqueológica de los edificios prerrománicos de San Martín de Elines", en Curso sobre el Patrimonio Histórico, 7, Actas de los XIII Cursos Monográficos sobre el Patrimonio Histórico (Reinosa 2002), Santander, pp. 319-330.

Domingo Magaña, J. A. 2011: Capiteles tardorromanos y visigodos en la península ibérica (siglos IV-VIII d.C.). Tarragona. Institut Català d'Arqueologia Clàssica.

Escalona Monge, J. 2002: Sociedad y territorio en la alta Edad Media española. BAR International Series 1079. Oxford.

Escalona Monge, J., Azcárate Aguilar-Amat, P. y Larrañaga Zulueta, M. 2002: "De la crítica diplomática a la ideología política. Los diplomas fundacionales de San Pedro de Arlanza y la construcción de una identidad para la Castilla medieval", en C. Sáez (ed.), Libros y documentos en la Alta Edad Media. Los libros de derecho. Los archivos familiares, Actas del VI Congreso Internacional de Historia de la Cultura Escrita, vol. II, pp. 159-206.

Escudero Ruiz, A. 1942-1943: "Una iglesia mozárabe en Hérmedes de Cerrato (Palencia)", Boletín del Seminario de Estudios de Arte y Arqueología, 9, pp. 183-185.

Espinosa Ruiz, U. 1983: "La iglesia hispano-visigoda de Albelda. Avances de las excavaciones de 1979", Cuadernos de Investigación. Historia, 9, pp. 231-241.

Espinosa Ruiz, U. 2011: La iglesia de Las Tapias y los monasterios tardoantiguos de Albelda de Iregua y Nalda (La Rioja). Logroño. Universidad de La Rioja.

Fernández Flórez, J. A. 2002: La elaboración de los documentos en los reinos hispánicos occidentales (ss. VI-XIII). Institución Fernán González, Burgos.

Fontaine, J. 1973 1978: L'Art Prérroman Hispanique*. La Pierre-Qui-Vire. Yonne (traducción 1978: El Prerrománico. Madrid).

García de Castro, C. 1995: Arqueología cristiana de la alta Edad Media en Asturias. Oviedo.

García Guinea, M. Á. 2007: “Campoo - Los Valles”, en M. A. García Guinea,

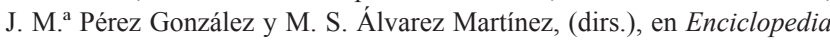
del Románico, Cantabria, vol. 3, Palencia.

Garen, S. 1997: "Transformations and creativity in visigothic period", en Antigüedad y Cristianismo, 14, pp. 511-524. 
Gómez Moreno, M. 1966: "Primicias del arte cristiano español", Archivo Español de Arte, 39, pp. 101-139.

Grondjis, L. H. 1952: "Une église manichéenne en Espagne", Comptes rendus de l'Académie des inscriptions et belles-lettres, 96, 3, pp. 490-497.

Harris, A. 2003: Byzantium, Britain \& the West. The Archaeology of Cultural Identity, $A D$ 400-650. Stroud: Tempus.

Heras y Nuñez, M. A. 1983: “Arte visigodo, prerrománico y románico”, en J. García Prado (ed.), Historia de La Rioja. Edad Media, t. II, pp. 26-49.

Heras y Núñez, M. ${ }^{a}$ A. 1986: Estructuras arquitectónicas riojanas. Siglos X al XIII. Logroño.

Heras, E.; Escribano, C. y Balado, A. 2001: "San Miguel de Gormaz (Soria). Estudio y puesta en valor de un edificio histórico", en V Congreso de Arqueología Medieval Española (Valladolid 1999), Valladolid, t. 1: pp. 393-405.

del Hoyo Calleja, J. en prensa: "El ejemplo de Quintanilla de las Viñas (Burgos)", VI Congreso Internacional de Latín Medieval Hispánico (marzo 2013. La Nucía, Alicante). Universidad de Alicante.

Huerta Huerta, P. L. 2002: "Pedro. Ermita de la Virgen del Val", en M. Á. García Guinea y J. M. ${ }^{a}$ Pérez González (dirs.), Enciclopedia del Románico en Castilla y León. Soria, vol. II, pp. 781-784. Aguilar de Campoo.

Huidobro Serna, L. 1927: "El monasterio de San Pedro de Arlanza y su primer Compendio historial inédito (continuación)", Boletín de la Comisión Provincial de Monumentos Históricos y Artísticos de Burgos, 20, pp. 211-214.

Huidobro Serna, L. 1927-1928: "Santa María de las Viñas en Quintanilla de Lara", Boletín de la Comisión Provincial de Monumentos de Burgos, 19, 21-22, pp. 175, 238-242 у 266-268.

Huidobro Serna, L. 1928-1929: "El arte visigótico y de la Reconquista en Castilla”, Boletín de la Comisión Provincial de Monumentos Históricos y Artísticos de Burgos, 25-26, pp. 361-368 y 394-404.

Huidobro Serna, L. 1932: "Iglesia de Santa María en San Vicente del Valle (Belorado, Burgos)", Boletín de la Comisión Provincial de Monumentos Históricos y Artísticos de Burgos, 3, pp. 315-317, 334-341 y 359-365.

Íñiguez Almech, F. 1934: "La ermita de Santas Céntola y Elena de Siero (Burgos)”, Archivo Español de Arqueología, 28, pp. 135-138.

Íñiguez Almech, F. 1955: "Algunos problemas de las viejas iglesias españolas”, Cuadernos de Trabajos de la Escuela Española de Historia y Arqueología en Roma, VII, pp. 7-180.

Kingsley, K. 1980: Visigothic Architecture in Spain and Portugal: a study in masonry, documents and forma. Berkeley.

Lambert, E. 1955: "L'eglise visigothique de Quintanilla de las Viñas", Comptes Rendus de l'Academie des Inscriptions et Belles Lettres: pp. 483-493.

Larrea, J. J. 2007: "Construir iglesias, construir territorios: las dos fases altomedievales de San Román de Tobillas (Álava)", III Encuentro Internacional: Monasteria et Territoria. Elites, edilicia y territorio en el mediterráneo medieval (siglos V-XI), BAR Internacional Series S1719, pp. 321-336. Oxford.

López Domech, R. y Hernáez Urraca, J. 1998 : “El martirium de Santa Coloma (La Rioja)", Romanización y Cristianismo en la Siria Mesopotámica, Antigüedad y Cristianismo, 15, pp. 515-540.

Martín Bueno, M. A. 1973: "Novedades de Arqueología Medieval Riojana", Miscelánea de Arqueología Romana, Biblioteca de Estudios Riojanos, 1, pp. 197-200. Logroño.

Martín Viso, I. 1995: "Poblamiento y sociedad en la transición al feudalismo en Castilla: castros y aldeas en la Lora burgalesa", Stvdia Historica. Historia Medieval, 13, pp. 3-45.

Moreno Martín, F. J. 2011: La arquitectura monástica hispana entre la Tardoantigüedad y la Alta Edad Media, BAR International Series S2287. Oxford.

Noack-Haley, S. 1987: "En torno al 'arte mozárabe"”, II Congreso de Arqueología Medieval Española, T ${ }^{\circ}$ III, pp. 581-588. Madrid.

Ortego Frías, T. 1958: "La ermita visigoda de la Virgen del Val (Pedro, Soria)", Archivo Español de Arqueología, 21: pp. 222-230.

Ortego Frías, T. 1983: "La huella visigoda en territorio soriano", Boletín de la Sociedad Española de Amigos de la Arqueología, 17: pp. 9-17.

Orueta, R. de. 1928: "La ermita de Quintanilla de las Viñas, en el campo de la Antigua Lara. Estudio de su escultura", Archivo Español de Arte y Arqueología, 12, pp. 169-178.
Osaba y Ruiz de Erenchun, B. 1951: "Museo Arqueológico de Burgos (Adquisiciones)", Memorias de los Museos Arqueológicos Provinciales, 11, pp. 160-162.

Osaba y Ruiz de Erenchun, B. 1952: "Quintanilla de las Viñas”, Memorias de los Museos Arqueológicos Provinciales, 13, pp. 34-36.

Osaba y Ruiz de Erenchun, B. 1976: "El arte árabe y sus huellas", en Cruz, V. de la. (ed.): Arte burgalés. Quince mil años de expresión artística: pp. 68-84. Vitoria.

Palol i Salellas, P. de. 1956: "Esencia del arte hispánico de época visigoda: romanismo y germanismo", I Goti in Occidente, Settimane di Studio del Centro Italiano sull'Alto Medioevo, 3, pp. 65-126. Spoleto.

Palomero, F. 2002: "Santa María de Retortillo", en García Guinea, M. A. y Pérez González, J. M. a (dirs.): Enciclopedia del Románico en Castilla y León, vol. IV, pp. 2621-2632. Aguilar de Campoo.

Pastor Díaz de Garayo, E. 1996: Castilla en el tránsito de la Antigüedad al feudalismo. Junta de Castilla y León. Valladolid.

Peña Bocos, E. 1993: "Las presuras y la Repoblación del valle del Duero: algunas cuestiones en torno a la atribución y organización social del espacio castellano en el siglo IX", en Repoblación y reconquista. Actas del III Curso de Cultura Medieval, pp. 249-259. Aguilar de Campoo.

Pérez de Urbel, J. 1945: Historia del condado de Castilla, 3 vols. Escuela de Estudios Medievales, CSIC. Madrid.

Pérez de Urbel, J. 1969-1970: El condado de Castilla: los 300 años en que se hizo Castilla. Siglo Ilustrado. Madrid.

Porter, A. K. 1928: Spanish Romanesque Sculpture, Firenze; edición española, 1929: La escultura románica en España, Florencia y Barcelona.

Puig i Cadafalch, J. 1961: L'Art wisigothique et ses survivances. Paris.

Real, M. L. 2007: “A escultura decorativa em Portugal: o grupo "portucalense",", en L. Caballero y P. Mateos (eds.), Escultura decorativa tardorromana y altomedieval en la Península Ibérica, Anejos de AEspA, XLI, pp. 133-170. CSIC, Madrid.

Sacristán de Lama, D. 1991-1992: "Burgos”, Numantia, 5, pp. 247-260.

Sáenz Preciado, M. ${ }^{\text {a }}$ P. 1999: "Tricio (La Rioja): últimas actuaciones realizadas en la Ermita de Nuestra Señora de los Arcos”, Estrato, 10, pp. 11-19.

Sánchez Zufiaurre, L. 2007: Técnicas constructivas medievales. Nuevos documentos arqueológicos para el estudio de la Alta Edad Media en Álava. Vitoria-Gasteiz.

Sánchez Zufiaurre, L. 2009: "Metodología. Las iglesias de Álava de los siglos IX-XI y las consideradas iglesias del siglo VII", en L. Caballero, P. Mateos, y M. a Á. Utrero (eds.), El siglo VII frente al siglo VII: Arquitectura, Anejos de AEspA, 51, pp. 231-240.

Santos Jener. S. de los. 1958: "Las artes en Córdoba durante la dominación de los pueblos germánicos", Boletín de la Real Academia de Córdoba, 29, pp. 147-192.

Sastre de Diego, I. 2013: Los altares de las iglesias hispanas tardoantiguas y altomedievales. Estudio arqueológico. BAR International Series 2503. Archaeopress, Oxford.

Schlunk, H. 1945: "Observaciones en torno al problema de la miniatura visigoda", Archivo Español de Arte, 71, pp. 241-265.

Schlunk, H. 1947: Arte Hispanovisigodo. Arte Asturiano, en Ars Hispaniae, vol. II. Madrid.

Schlunk, H. 1971: "La iglesia de S. Giâo, cerca de Nazaré: Contribución al estudio de la influencia de la liturgia en la arquitectura de las iglesias prerrománicas en la península Ibérica", Actas do II Congresso Nacional de Arqueologia, pp. 509-528. Coimbra.

Schlunk, H. y Hauschild, Th. 1978: Die Denkmäler der frühchristlichen und westgotischen Zeit. Mainz am Rheín.

Schlunk, H. 1978-1980: "El arte asturiano en torno al 800", en Actas del Simposio para el estudio de los códices del "Comentario al Apocalipsis" de Beato de Liébana (Madrid 1976), t. . I, 2, pp. 136-164. Madrid.

Sepúlveda González, M. ${ }^{\text {a }}$ de los Á. 1986: "Los anagramas y el programa iconográfico de Quintanilla de las Viñas: una hipótesis de interpretación", en La España Medieval V, Estudios en memoria del profesor D. Claudio Sánchez Albornoz, vol. II, pp. 1217-1237. Madrid.

Serrano, L. 1925: Cartulario de San Pedro de Arlanza (antiguo monasterio benedictino). Burgos. 
Taracena, B. 1927: "Excavaciones en las provincias de Soria y Logroño", en Memorias de la Junta Superior de Excavaciones y Antigüedades, 86. Madrid.

Taracena, B. 1942: "Restos romanos en La Rioja", Archivo Español de Arqueología, 46, pp. 17-47.

Toribios, I. y Saiz, R. 1925: "La ermita de Santa Cecilia entre Santibañez del Val y Barriosuso", Boletín de la Sociedad Española de Excursiones, 33, pp. 197-209.

Uranga Galdiano, J. E. e Íñiguez Almech, F. 1971: Arte Medieval Navarro. Arte Prerrománico. Aranzadi. Pamplona.

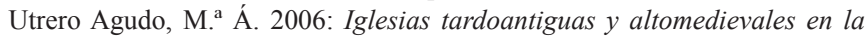
Península Ibérica. Análisis arqueológico y sistemas de abovedamiento, Anejos de AEspA, 40. CSIC, Madrid.

Utrero Agudo, M. Á. 2007: “Arquitectura alto medieval peninsular. Nuevas aportaciones al estudio de las estructuras abovedadas. Las iglesias de San
Esteban de Canejada y Santo Domingo de Valdegutur (La Rioja)", Cesaraugusta, 78, pp. 699-710.

Utrero Agudo, M. á. en prensa: "Bisanzio e l'architettura tardoantica e altomedievale ispanica. Revisione di un lungo legame", en R. Martorelli (ed.), Tributo al professore Roberto Coroneo. Università di Cagliari.

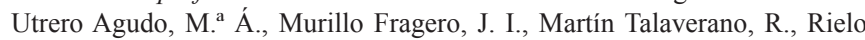
Rincón, M., Villa del Castillo, A., Moreno Martín, F., Álvarez Areces, E. y Baltuille Martín, J. M., en prensa: "San Pedro de La Mata (Sonseca, Toledo). Construir y decorar una iglesia altomedieval en piedra", en Archivo Español de Arqueología.

Williams, J. 1970: "A contribution to the history of the castilian monastery of Valeranica and the scribe Florentius", Madrider Mitteilungen, 11, pp. 231-248. Whitehill, W. M. y Clapham, A. W. 1937: "The Church of Quintanilla de las Viñas", Antiquaries Journal, 17, pp. 16-27.

Yarza, J. 1979: Arte y Arquitectura en España. 500/1250. Madrid. 